\title{
Review
}

\section{Species list of the European herpetofauna - 2020 update by the Taxonomic Committee of the Societas Europaea Herpetologica}

\author{
Jeroen Speybroeck $^{1, *}$, Wouter Beukema ${ }^{2}$, Christophe Dufresnes ${ }^{3}$, Uwe Fritz ${ }^{4}$, Daniel Jablonski ${ }^{5}$, \\ Petros Lymberakis $^{6}$, Iñigo Martínez-Solano ${ }^{7}$, Edoardo Razzetti ${ }^{8}$, Melita Vamberger ${ }^{4}$, \\ Miguel Vences ${ }^{9}$, Judit Vörös ${ }^{10}$, Pierre-André Crochet ${ }^{11}$
}

\begin{abstract}
The last species list of the European herpetofauna was published by Speybroeck, Beukema and Crochet (2010). In the meantime, ongoing research led to numerous taxonomic changes, including the discovery of new species-level lineages as well as reclassifications at genus level, requiring significant changes to this list. As of 2019, a new Taxonomic Committee was established as an official entity within the European Herpetological Society, Societas Europaea Herpetologica (SEH). Twelve members from nine European countries reviewed, discussed and voted on recent taxonomic research on a case-by-case basis. Accepted changes led to critical compilation of a new species list, which is hereby presented and discussed. According to our list, 301 species (95 amphibians, 15 chelonians, including six species of sea turtles, and 191 squamates) occur within our expanded geographical definition of Europe. The list includes 14 non-native species (three amphibians, one chelonian, and ten squamates).
\end{abstract}

Keywords: Amphibia, amphibians, Europe, reptiles, Reptilia, taxonomy, updated species list.

\section{Introduction}

1 - Research Institute for Nature and Forest, Havenlaan 88 bus 73, 1000 Brussel, Belgium

2 - Wildlife Health Ghent, Department of Pathology, Bacteriology and Avian Diseases, Ghent University, Salisburylaan 133, 9820 Merelbeke, Belgium

3 - LASER, College of Biology and the Environment, Nanjing Forestry University, Nanjing, China

4 - Museum of Zoology, Senckenberg Dresden, A.B. Meyer Building, Königsbrücker Landstraße 159, 01109 Dresden, Germany

5 - Department of Zoology, Comenius University in Bratislava, Ilkovičova 6, Mlynská dolina, 84215 Bratislava, Slovakia

6 - Natural History Museum of Crete, University of Crete, Knossou Ave. 71409, Crete, Irakleio, Greece

7 - Museo Nacional de Ciencias Naturales (MNCNCSIC), c/ José Gutiérrez Abascal, 2, 28006 Madrid, Spain

8 - Kosmos - Museo di Storia Naturale, Università di Pavia, Piazza Botta 9, 27100 Pavia, Italy

9 - Division of Evolutionary Biology, Zoological Institute, Braunschweig University of Technology, Mendelssohnstr. 4, 38106 Braunschweig, Germany

10 - Department of Zoology, Hungarian Natural History Museum, 1088 Budapest, Baross u. 13, Hungary
Speybroeck, Beukema and Crochet (2010) (SBC2010, hereafter) provided an annotated species list for the European amphibians and non-avian reptiles. A decade later, a sizable amount of new research has been produced, fuelling the need for a contemporary update. Within the European Herpetological Society (Societas Europaea Herpetologica; SEH) and by invitation of the SEH Council, a newly composed Taxonomic Committee (SEH TC, or further TC) was formed in early 2019, and its chair was approved by SEH membership during the Ordinary General Meeting held in Milan,

11 - CEFE, Université Montpellier, CNRS, EPHE, IRD, Université Paul Valéry Montpellier 3, Montpellier, France

*Corresponding author; e-mail: jeroen.speybroeck@inbo.be 
September 5th 2019 (SEH News, AmphibiaReptilia 40: 551-559).

We did not define our own limits for the geographical area considered here, but adopted the limits defined by previous projects. Our goal was to provide a taxonomic reference for the future mapping projects of the SEH. Therefore, we included all areas that were part of previous European atlas projects (cf. Gasc et al., 1997; Sillero et al., 2014). We also aimed at informing the taxonomic backbone of the Fauna Europaea initiative (https://fauna-eu.org), and therefore our geographical area also includes all territories that are covered by Fauna Europaea. As a result, we enlarged the geographical area considered by SBC2010 to encompass all areas covered by both Gasc et al. (1997) and Fauna Europaea. Areas included by Gasc et al. (1997), but not by Speybroeck, Crochet and Beukema (2010), include the northern versant of the Caucasus (including north-eastern Azerbaijan), all areas west of the Ural River (including westernmost Kazakhstan) and west of the Ural Mountains, and the Yekaterinburg Region. Areas included in Fauna Europaea, but not by Gasc et al. (1997) or SBC2010, are Macaronesia (without Cape Verde), the Greek Islands off the western Anatolian shore, and Cyprus. As such, our area exceeds that of the most recent European atlas (Sillero et al., 2014) by including Macaronesia, all Greek islands, and parts of Azerbaijan and Kazakhstan (fig. 1). A Google Earth . $\mathrm{kml}$ file with the limits of the area is provided in the supplementary material. For the rationale of these limits, we refer to Gasc et al. (1997) and https://fauna-eu.org/data-handling).

Upon enlarging the scope area and prior to discussing any taxonomic changes, a broader baseline list had to be set for species occurring outside the area considered by SBC2010. As such, in addition to SBC2010, we followed the taxonomy of Gasc et al. (1997, 2004, including the changes adopted by Dubois and Crochet in the 2004 reprint), and for species outside Europe (including Macaronesia and Cyprus), Sindaco and Jeremčenko (2008) and Sindaco,
Venchi and Grieco (2013). Together, these four sources led to a starting point species list. In the following, we only discuss taxonomic changes which deviate from this species list. We decided against using online databases as starting points, as they are changing constantly, with historical versions not remaining reliably and easily available.

The taxonomic decisions adopted here are not necessarily supported by all authors of this work. According to TC guidelines, a change to the starting list will only be adopted if widely supported among its members, specifically by a $>75 \%$ majority. When a change is recommended by a large majority of the TC members, but different members favour different outcomes, the adopted solution may be supported by only a simple majority $(>50 \%)$. Note that this process favours taxonomic stability, with changes requiring large support among TC members to become accepted.

TC members do not necessarily adhere to the same species concept. While many agree with the General Lineage Concept (GLC) of De Queiroz (2007), some prefer the general framework of the Biological Species Concept. However, all agree on using reproductive isolation as the primary operational criterion for the delimitation of species. The majority of TC members is of the opinion that, while every species is a lineage, not every lineage is a species. The common approach can be defined as either following the Biological Species Concept framework, or as applying a Biological Species Criterion under the GLC. More specifically, TC members adhere to a "soft" version of the reproductive isolation criterion. As such, we allow extensive introgression between recognised species, as long as there are intrinsic barriers to gene flow that prevent wide-reaching introgression beyond the contact zones. Even in the absence of geographical barriers, a sufficient level of reproductive isolation has to exist in order to ensure longterm persistence of the diverged lineages. Taxa connected by bimodal or trimodal hybrid zones (Gay et al., 2008) were unanimously treated as 





valid species, but opinions often differed regarding how much introgression was "allowed" across unimodal hybrid zones, reflecting different opinions relative to where to cut the grey zone of speciation, how much reproductive isolation is necessary and when to treat incipient species as valid species. For allopatric taxa, or when contact zones were not studied, lineages that had divergence levels similar to closely related, unambiguously distinct species were accepted as species. As an auxiliary criterion, we sometimes use monophyly, even though we do not consider it as a necessary requirement for species status.

For supraspecific classification, the TC agreed to accept only monophyletic units. This causes issues regarding the class Reptilia, which in its traditional definition is paraphyletic through the exclusion of birds. All current hypotheses on the evolution of vertebrates agree that a group including squamates, turtles, Sphenodon and crocodiles, but not birds is paraphyletic (see e.g. Chiari et al., 2012a; Hasegawa, 2017). As a consequence, most current classifications of Vertebrata include Aves in the class Reptilia (see e.g. Modesto and Anderson, 2004; Ruggiero et al., 2015). To avoid confusion, we adopt the term 'non-avian reptiles' to refer to the components of the European fauna assigned to Testudines/Chelonii and Squamata.

For nomenclatural decisions, including spelling, we followed the International Code of Zoological Nomenclature (the Code hereafter, ICZN (1999 and subsequent changes), see https://www.iczn.org/). Such decisions were generally not submitted to voting, but they could be discussed, as many parts of the Code can be subject to interpretation, and many actual cases can be open to different decisions, even under the rules of the Code.

In the following, we review taxonomic and nomenclatural changes proposed since the publication of the four literature sources that we used to build our starting point, as well as other relevant new information pertaining the taxonomy of European amphibians and non-avian reptiles. For each case, we provide the rationale underlying the respective decision of the TC, and conclude by providing an updated species list of the European herpetofauna.

\section{Amphibia}

\section{Caudata/Urodela}

A series of phylogenetic studies on mitochondrial DNA, allozymes, and nuclear DNA sequences of members of the family Salamandridae (Litvinchuk et al., 2005; Weisrock et al., 2006; Zhang et al., 2008; Kieren et al., 2018; Veith et al., 2018) confirmed that the newt genus Triturus sensu lato, as traditionally recognised, is not monophyletic. Litvinchuk et al. (2005) proposed the separation of Triturus into four genera, among which the new genus Ommatotriton contains (the former) Triturus vittatus. SBC2010 accepted this new arrangement, but did not explicitly acknowledge the need to recognise Ommatotriton, as the new genus does not occur in the area they considered. As we herein consider a wider area, we formally accept Ommatotriton as a separate genus.

Litvinchuk et al. (2005) also showed that morphology (number of trunk vertebrae, colour pattern), genome size, and allozymes (Nei's genetic distances of 0.44-0.83) strongly differ between populations in the two widely disjoint areas inhabited by Ommatotriton vittatus, namely south-eastern Anatolia and the Levant (O. v. vittatus) versus the southern and eastern Black Sea and western Caucasus regions (O. v. ophryticus). This led them to elevate ophryticus to species level. A more comprehensive study also demonstrated restricted introgression between an eastern and a western taxon along the Black Sea coast of Turkey (van Riemsdijk et al., 2017). Consequently, we recommend to recognise three species in the genus Ommatotriton: $O$. vittatus (extralimital) in south-eastern Anatolia and the Levant, O. ophryticus in Russia, the Caucasus and northern Anatolia west to the region of Samsun, and O. nesterovi (extralimital) 
in Anatolia from Samsun to the Sea of Marmara. The populations inhabiting the native Ommatotriton range in the European part of Russia belong to $O$. ophryticus, while the introduced (and persisting anno 2019; Speybroeck, pers. obs.) population in north-eastern Spain is of mixed ancestry, with genetic contribution from both $O$. ophryticus and $O$. nesterovi (van Riemsdijk et al., 2018).

In addition to mtDNA sequences, Vences et al. (2014) used sequences from thirteen nuclear loci to improve our understanding of the history of the genus Salamandra. Their nuclear data suggest that Salamandra salamandra contains several deeply divergent lineages whose monophyly relative to $S$. algira received weak support, although this requires confirmation. Based on mitochondrial data the subspecies longirostris is sister to all other $S$. salamandra lineages. However, nuclear genes place it with the subspecies morenica. The discordance between mtDNA and nuclear genes may result from past introgression and admixture processes. Furthermore, a clade comprising the subspecies fastuosa, bernardezi (including populations attributed to the subspecies alfredschmidti, whose validity was rejected, as it is phylogenetically nested within several subclades of bernardezi; Beukema et al., 2016) and gigliolii is recovered with strong support. While additional data are clearly needed, this suggests a high amount of evolutionary divergence within S. salaman$d r a$, and the existence of more than one species within $S$. salamandra cannot yet be fully ruled out.

SBC2010 recognised two species within the former Triturus karelinii: T. arntzeni from the Balkan Peninsula, and T. karelinii. Wielstra et al. (2013) suggested that the type specimens of T. arntzeni are in fact T. macedonicus, which led them to place $T$. arntzeni in the synonymy of T. macedonicus, and to create the name ivanbureschi for the taxon of the karelinii complex that occurs in the Balkans and in Western Anatolia. Later, Wielstra and Arntzen (2014) demonstrated that the types of T. arntzeni are in fact the result of ancient admixture between $T$. macedonicus and T. ivanbureschi. We do not entirely agree with their interpretation of the Code. As they rightfully state, nomina based on genetically admixed individuals derived through several generations of backcrossing are indeed left in limbo in the Code. Yet, we do not agree that the Code should be interpreted as extending provisions of Art. 23.8 to nomina based on genetically admixed individuals, at least not without clear guidelines of what constitutes admixture in the sense of the Code. We do, however, agree with Wielstra and Arntzen (2014) that arntzeni, based on individuals that carry less than $50 \%$ of alleles derived from the karelinii-complex taxon, should not be used as the valid name for that taxon. We thus accept $T$. ivanbureschi as the valid nomen of the taxon of the kareliniicomplex that occurs in Europe in the Balkans. With the extension of the geographic range of SBC2010, T. karelinii sensu stricto also occurs in our area in Russia, the Crimean Peninsula and the Caucasus region.

Using mitochondrial and nuclear DNA sequences, Sotiropoulos et al. (2007) and Recuero et al. (2014) investigated the phylogenetic structure of Ichthyosaura alpestris. They identified several deeply divergent lineages that largely correspond to currently recognised subspecies, except for the subspecies alpestris, which is further divided into a western and an eastern main lineage. Interestingly, nuclear sequences from two loci show a nearly complete lack of allele sharing between the eastern and western clades, suggesting reproductive isolation between them. However, no samples were collected close to their contact zones. As the eastern and western clades should meet in the Balkans and the southern Carpathian Mountains, we follow the recommendation of $\mathrm{Re}$ cuero et al. (2014) and await more data on their level of reproductive isolation before making any taxonomic change. Thus, we do not follow Raffaëlli (2018) who (based on the genetic data presented in the aforementioned studies) elevated the subspecies apuana, reiseri and 
veluchiensis to species level, and we note that such changes would make I. alpestris polyphyletic. We thus retain I. alpestris as a single species for now.

Pabijan et al. (2017) reconstructed phylogenetic relationships within the Lissotriton vulgaris species complex and inferred patterns of (historical) gene flow, using 74 nuclear DNA markers from one individual from each of 127 locations. Five highly divergent lineages were identified within our focal area: Lissotriton montandoni and four lineages corresponding to the Lissotriton vulgaris subspecies graecus, lantzi, schmidtleri and vulgaris. In spite of clear evidence of past historical introgression, their contemporary gene flow is restricted. Therefore, the authors proposed to treat the three former subspecies as species (Pabijan et al., 2017). Between $L . v$. vulgaris and the morphologically diverged L. v. meridionalis regular episodes of gene flow were identified, thus meridionalis was retained at subspecies level. While L. v. graecus is easily distinguished from other $\mathrm{Eu}-$ ropean populations by male nuptial characteristics, both L. v. lantzi and L. v. schmidtleri are morphologically cryptic in respect to $L$. $v$. vulgaris (Raxworthy, 1990). Rather than being confined to Anatolia, Pabijan et al. (2015, 2017) showed that L. v. schmidtleri also occurs in Greek and Turkish Thrace and on a number of Greek islands. Because the sampling gaps between several of the lineages remained wide, the TC has been reluctant to accept all systematic conclusions of Pabijan et al. (2017). The taxon graecus comes into close contact with $L$. v. vulgaris along the northern and eastern borders of its distribution. Although no dense sampling has been performed to delineate the contact zone in detail, and mitochondrial introgression from southern L. v. vulgaris into graecus occurs at its northern range border (Pabijan et al., 2017), nuclear gene pools of these two taxa appear to remain reciprocally distinct in relative close geographical proximity (Pabijan et al., 2017; Wielstra et al., 2018). We therefore accept Lissotriton graecus as a valid species. For $L$. v. schmidtleri, its range limits and contact zones with other European lineages remain poorly known. Although data on the contact zone with L. v. kosswigi in Anatolia support a species-level divergence between $L$. v. schmidtleri and the graecus-kosswigi clade, areas of 100-300 km inhabited by $L$. vulgaris s.l. of unknown identity separate genotyped $L$. v. schmidtleri populations from those of L. v. vulgaris and L. graecus (Pabijan et al., 2017; Wielstra et al., 2018). The TC thus feels that more information on contact zones between L. v. schmidtleri and L. v. vulgaris is warranted before the species rank of schmidtleri can be accepted. Finally, L. v. lantzi is endemic to the Caucasus and shows an allopatric distribution (Wielstra et al., 2018). Mitochondrial data suggests that L. v. lantzi was the first to diverge from other lineages around 3.39 (1.42-5.37) Mya (Pabijan et al., 2015). Yet, nuclear data place $L$. v. lantzi as sister to $L$. $v$. schmidtleri and other eastern and central European Lissotriton, while suggesting that divergence within this group initiated with the split of the graecus-kosswigi clade (Pabijan et al., 2017). In conclusion, the TC recommends to treat Lissotriton graecus as a valid species, but, as awarding species status to lantzi but not to schmidtleri may render L. vulgaris paraphyletic, we prefer to maintain the other taxa, including L. v. schmidtleri and L. v. lantzi, as subspecies of $L$. vulgaris for the time being.

A phylogeographic study based on two mtDNA markers by Martínez-Solano et al. (2006) revealed two major mitochondrial lineages of Miocene origin in Lissotriton boscai. One of them is restricted to central and southwestern coastal Portugal, while the other occupies the remainder of the species range, including the type locality of L. boscai. MartínezSolano et al. (2006) acknowledged that the two lineages might represent cryptic species, but called for additional morphological and molecular studies, including data on variation in nuclear DNA markers. Dubois and Raffaelli (2009) resurrected the nomen Triton maltzani Boettger, 1879 for the southwestern lineage in 
the new combination Lissotriton maltzani. According to these authors, L. maltzani can be distinguished from $L$. boscai by its smaller size and by its paler dorsal coloration, especially in females, with less distinct dark spots. Teixeira et al. (2015) used DNA sequences of one nuclear gene and found overall congruence with mtDNA genes in terms of sequence divergence and geographic structure. They, however, also revealed wide areas of admixture and evidence for recombination, suggesting a lack of complete reproductive isolation and the presence of incomplete speciation. In a recent study, Sequeira et al. (2020) used ten microsatellites, one mtDNA gene and two single copy nuclear DNA markers in a cline analysis framework to investigate one of the hybrid zones between $L$. boscai and $L$. maltzani. The results show evidence for partial reproductive isolation between $L$. boscai and L. maltzani, with narrow clines $(3-28 \mathrm{~km})$ consistent with selection against hybrids. We thus recognise L. maltzani as a separate species.

Wake (2012) addressed the taxonomy of the Plethodontidae, advocating to treat Atylodes (comprising Speleomantes genei) and Speleomantes (comprising the other European plethodontid species) as subgenera of a single, cross-Atlantic genus Hydromantes. Addressing the genus name confusion, Wake (2013) compared five potential arrangements, missing however the arrangement of SBC2010 (i.e. two genera without subgenera). Comparing with other plethodontid genera, he argued in favour of an arrangement of a single genus with three subgenera. However, the arguments of SBC2010 still stand: the position of Atylodes remains unresolved, and the European species form a well-defined monophyletic group with a large genetic distance from the five Californian species Hydromantes brunus, H. platycephalus, $H$. samweli, $H$. shastae, and $H$. wintu (Nascetti et al., 1996; Pyron and Wiens, 2011; Chiari et al., 2012b; Bingham, Papenfuss and Wake, 2018). Thus, no change seems in order, and we maintain the European species for the time being in a single taxon, the genus Speleomantes.
Vörös, Ursenbacher and Jelić (2019) used 10 microsatellite loci to investigate patterns of differentiation between four Croatian cave populations of Proteus anguinus. They uncovered long-lasting isolation between caves belonging to different hydrogeographic systems, with the most ancient divergence being older than 7 Mya. This suggests that some of the evolutionary lineages within this species might constitute cryptic taxa, possibly of species rank (Vörös, Ursenbacher and Jelić, 2019).

\section{Anura}

Alytes obstetricans is composed of four subspecies: A. o. obstetricans, A. o. pertinax, A. o. boscai and $A$. o. almogavarii. The latter taxon is endemic to Catalonia and adjacent areas in north-eastern Spain and southern France, and it is highly differentiated in allozyme (Arntzen and García-París, 1995; García-París, 1995), mitochondrial (Gonçalves et al., 2007, 2015) and microsatellite markers (Maia-Carvalho et al., 2018), and features peculiar osteological (Martínez-Solano et al., 2004) and bioacoustics characters (Márquez and Bosch, 1995). Possibly due to ancestral hybridisation or incomplete lineage sorting (Gonçalves et al., 2007; Maia-Carvalho et al., 2014), the nuclear phylogeny, based on intron sequences, is not well resolved. Using microsatellites, Maia-Carvalho et al. (2018) identified a distinct cluster corresponding to all $A$. o. almogavarii populations, suggesting that the lack of monophyly in mtDNA data is due to cyto-nuclear discordance. This cluster extends as far west as the southern slopes of the Pyrenees in the north-westernmost parts of Aragon. These authors also found restricted genetic admixture between A. o. almogavarii and neighbouring subspecies (A. o. pertinax, A. o. obstetricans). Following up on this study, Dufresnes and Martínez-Solano (2020) targeted the hybrid zone between A. o. almogavarii and $A$. $O$. pertinax with genomic analyses using RADseq-derived markers along a finescale transect in Catalonia. They documented a very narrow mitochondrial (cline width ca. 
$13 \mathrm{~km}$ ) and nuclear (cline width ca. $16 \mathrm{~km}$ ) transition, and detected portions of the genome that were completely impermeable to gene flow. Given the absence of barriers to dispersal in the contact zone, the authors concluded that these lineages exhibit substantial (even if incomplete) reproductive isolation. We adopt their recommendation and treat Alytes almogavarii as a distinct species.

Pabijan et al. (2012) found a lack of reciprocal monophyly in nuclear data of Iberian painted frogs (Discoglossus spp.), while Dufresnes et al. (2020a) found numerous introgressed individuals in their RAD datasets and a broad hybrid zone (average cline width of nuclear markers $>136 \mathrm{~km}$ ). These results indicate weak (or no) restriction to gene flow and confirm that D. g. galganoi and D. g. jeanneae are better treated as conspecific, as previously advocated by SBC2010.

Borkin et al. (2001) reported differences in genome size between the morphologically similar eastern and western populations of Pelobates fuscus, with a transition between both groups in north-eastern Ukraine and adjacent parts of Russia. The name Rana vespertina Pallas, 1771 is available for the eastern taxon. Subsequently, analyses using mtDNA data across the entire species range confirmed the existence of two major mitochondrial lineages (Crottini et al., 2007). Litvinchuk et al. (2013) confirmed that these two lineages differ in their nuclear genomes, with Nei's genetic distance based on allozymes being similar to the divergence between Pelobates syriacus syriacus and P. s. balcanicus (see below), and with a restricted introgression zone. Based on its independent evolutionary history, they thus proposed to treat vespertinus as a species. More recently, based on RADseq data, Dufresnes et al. (2019a) reported narrow clines between fuscus and vespertinus (average nuclear cline width: $16 \mathrm{~km}$ ). On the basis of the narrow hybrid zone, indicating strong (albeit incomplete) reproductive isolation, and in spite of the relatively recent divergence of this taxon (between 2 and 3 Mya, see Dufresnes et al., 2019a, b), we accept the specific rank of Pelobates vespertinus.

Dufresnes et al. (2019a) also demonstrated complete reproductive isolation between Pelobates syriacus syriacus and P. s. balcanicus, warranting elevation of European populations, except those from south-eastern Bulgaria, parts of European Turkey and a number of eastern Greek islands (including Limnos and Lesbos), to species level as Pelobates balcanicus, with an estimated Mio-Pliocene divergence (>5 Mya) between both taxa. Deep intraspecific divergence within each species further leads to recognise the subspecies $P$. balcanicus chloeae (Peloponnese) and P. syriacus boettgeri (all European parts of the distribution of Pelobates syriacus).

The complex pattern of genetic variation within Iberian Pelodytes has been known for several years (e.g., van de Vliet et al., 2012). It was taxonomically formalised by DíazRodríguez et al. (2017), who described two new species: Pelodytes atlanticus from Portugal and $P$. hespericus from central eastern Spain, in addition to the previously established species, $P$. ibericus and $P$. punctatus. The two new lineages show no consistent morphological or bioacoustics differences, are only weakly differentiated in mtDNA $(<2 \%$ in the $16 \mathrm{~S}$ rRNA gene, $<7 \%$ in COI), but show limited sharing of nuclear alleles. Díaz-Rodríguez et al. (2017) recognised that this was a disputable case, in which, for the time being, "species status for all four western lineages of Pelodytes [was] the hypothesis best fitting the available data". A new study by Dufresnes et al. (2020a), based on RADseq-derived loci from spatially dense sampling, found that $P$. atlanticus and $P$. ibericus are separated by a narrow hybrid zone, featuring little introgression, whereas the contact zone of $P$. hespericus and $P$. punctatus has a considerably more flattened cline, with an introgression zone possibly extending up to $200-300 \mathrm{~km}$. There is no known contact zone between $P$. atlanticus and P. hespericus. While the position of $P$. atlanticus (sister to ibericus or to hespericus) remains unresolved, its genetic divergence 
from hespericus and punctatus is quite large. We thus follow the suggestion of Dufresnes et al. (2020a) to accept $P$. atlanticus as separate species, while retaining hespericus at subspecies level as $P$. punctatus hespericus.

Despite growing support for recognition of various clades in the family Bufonidae as separate genera (Stöck et al., 2006; Van Bocxlaer et al., 2009), several authors advocated retaining Bufo for all species from the Western Palaearctic and Central Asia, at least as an ad interim solution (Dubois and Bour, 2010; SBC2010). Formal taxonomic action was further hampered by nomenclatural confusion, such as the use of either Pseudepidalea or Bufotes as the valid generic nomen for the green toad group (Frost et al., 2006; Dubois and Bour, 2010). Dubois and Bour (2010) demonstrated that Pseudepidalea is a junior objective synonym of $\mathrm{Bu}$ fotes, thereby giving priority to the latter. However, based on the presence of hybridisation between representatives of these clades, and the restricted sampling size of previous studies, Dubois and Bour (2010) listed these nomina as subgenera, rather than genera. According to Van Bocxlaer et al. (2010), Pyron and Wiens (2011), and Beukema et al. (2013), which together provide a dense sampling of bufonid species, most genera currently recognised by Frost (2019) represent well-supported monophyletic units. Moreover, time-calibrated analyses showed Bufo, Bufotes and Epidalea to be of similar age as or older than most other recognised bufonid genera (Beukema et al., 2013). Considering these results, we accept $B u f o, B u$ fotes and Epidalea at genus level.

Recuero et al. (2012) published a multilocus mitochondrial and nuclear DNA sequence data set for Bufo bufo and associated species, covering the entire documented range and providing extensive genetic data. The study yields a fully resolved phylogeny, with the recently described Bufo eichwaldi from the Talysh Mountains of southern Azerbaijan and northern Iran as the sister taxon of a clade including three deeply diverged lineages: i) north African, Iberian, and most French populations of Bufo bufo (for which the name Bufo spinosus is available), and a clade composed of two lineages, representing ii) verrucosissimus from the Caucasus and iii) bufo from northern France to Russia, while populations from Greece, southern Italy and Sicily and most of Anatolia carried bufo mtDNA but grouped with verrucosissimus in nuclear DNA. Estimations of divergence times indicated a long evolutionary history of the group, starting with the split from eichwaldi at about 12 Mya, and the divergence of spinosus taking place around 6 Mya. The deep level of genetic divergence observed between the western and eastern groups of common toads indicated that these groups may be different species. However, Garcia-Porta et al. (2012) found extensive admixture of mitochondrial lineages between the eastern and western clades in the Languedoc area of southern France (as also reported by Arntzen et al., 2017 for the Provence area of southern France), and detected signs of ancient introgression of bufo allozyme alleles into spinosus. They thus suggested to treat $B . b$. spinosus and $B$. b. bufo as conspecific pending studies of the contact zones. Detailed analysis of the amount of reproductive isolation in two geographically distant contact zones on the basis of mtDNA, morphology and nuclear markers have subsequently been published by Arntzen et al. (2016, 2017). Both studies documented an extensive amount of hybridisation and introgression in the contact zone, but also the presence of narrow and concordant clines for most nuclear markers, resulting in a unimodal, yet narrow hybrid zone of ca. $30 \mathrm{~km}$ wide, and indicating intrinsic barriers to gene flow in spite of incomplete reproductive isolation. Karyological analysis (albeit based on only four males and a single female) identified heteromorphic sex chromosomes in spinosus, but not in bufo (Skorinov et al., 2018). The combined available evidence justifies treating Bufo spinosus as a distinct species. 
Based on differences in morphology and karyotype and a study suggesting lowered fertility of F1 hybrids (summary in Kuzmin, 1999), the Caucasian populations of the complex are sometimes also treated as a distinct species as Bufo verrucosissimus. Recent genetic studies paint a more complex picture. Firstly, based on nuclear markers, the Anatolian populations, traditionally excluded from $B . b$. verrucosissimus on the basis of morphology, are in fact genetically closer to this group than to $B . b$. bufo or $B$. spinosus, even if they carry $B . b$. bufo mtDNA (Garcia-Porta et al., 2012; Arntzen et al., 2013). Secondly, mtDNA divergence between Caucasian (B. b. verrucosissimus) and Eastern European (B. b. bufo) populations is much lower than between $B$. b. bufo and B. spinosus. Indeed, divergence in mtDNA and allozymes between the Caucasian and Eastern European lineages is even lower than between the subclades of B. spinosus (Garcia-Porta et al., 2012). Most importantly, based on frequencies of allozyme alleles, populations of $B$. $b$. bufo from Greece and north-western Turkey appear intermediate between Caucasian and European populations (Garcia-Porta et al., 2012) or group with Caucasian populations in nuclear trees (Recuero et al., 2012), suggesting extensive introgression between $B$. b. verrucosissimus and $B . b$. bufo in north-western Turkey and the southern Balkans (but see Arntzen et al., 2013). In our opinion, the specific status of $B . b$. verrucosissimus is currently insufficiently supported by the available evidence, and we maintain it as conspecific with Bufo bufo for the time being.

Stöck et al. (2006) elevated a number of mitochondrial lineages of green toads (now Bufotes) to species level (for Europe: B. variabilis and $B$. balearicus, in addition to $B$. viridis) and subsequently described a new species from Sicily based on the same lines of evidence. SBC2010 argued against accepting these species on the basis of mitochondrial DNA alone. Colliard et al. (2010) documented a contact zone in Sicily between the taxa siculus and balearicus (sensu
Stöck et al., 2006) and demonstrated strong reproductive isolation between them. As these two taxa belong to the two most divergent lineages (North African and Eurasian), a twospecies split of the green toad complex is clearly warranted. The Sicilian taxon siculus is closely related to the North African taxon boulengeri, which has priority over siculus. Subsequently, nuclear data were added to the picture (microsatellites - Dufresnes et al., 2018a; Gerchen, Dufresnes and Stöck, 2018, and RADseq markers - Dufresnes et al., 2019c). Although cytonuclear discordance was present in large areas of Europe where populations of viridis carry the variabilis mtDNA lineage, these studies confirmed that overall the previously identified mtDNA lineages correspond to distinct evolutionary units. Dufresnes et al. (2019c) also discovered that the type locality of variabilis is inhabited by the western lineage, rendering variabilis a junior synonym of viridis, and that the valid name for the Anatolian lineage is sitibun$d u s$. These two lineages (B. v. sitibundus and $B$. v. viridis) widely admix over a very large geographic area in Anatolia and Russia (Dufresnes et al., 2019c), suggesting that they are best treated as subspecies. The contact zone between $B$. v. viridis and B. v. balearicus is narrower $(63 \mathrm{~km})$, but still extensive if compared with other contact zones between taxa that are here treated as different species (Gerchen, Dufresnes and Stöck, 2018). In addition, raising B. v. balearicus but not $B$. v. sitibundus to species rank would make $B$. v. viridis paraphyletic (see Dufresnes et al., 2019c). The TC therefore preferred to treat B. v. sitibundus and B. v. balearicus (and the extralimital B. v. perrini) as subspecies of $B$. viridis.

Dufresnes et al.'s (2019c) range-wide sampling of all known taxa of the Bufotes viridis complex identified a total of eight diploid genetic clusters, including a new lineage endemic to Cyprus, which they describe as Bufotes cypriensis. Estimated to be of Messinian origin (5.3 Mya), this insular taxon is as old as or older than many species of anuran amphibians 
from the Western Palearctic. Yet, all ten individuals from four localities carry mtDNA haplotypes of B. v. sitibundus. Secondary contact and hybridisation with the Anatolian mainland lineage during the Pleistocene would explain this mitochondrial capture, as well as the remnants of nuclear introgression that were detected as well. In addition to this deep genomic divergence, the genome of B. cypriensis is also significantly larger than that of all other Western Palearctic Bufotes taxa. Morphologically, the Cyprus green toads are smaller than those from mainland populations, as previously reported by Stugren and Tassoula (1987). The combination of an old divergence and a larger genome size led the TC to accept the species status of B. cypriensis. Adriatic populations could represent a valid subspecies of $B$. viridis (for which the nomen longipes Fitzinger in Bonaparte, 1840 might be available), while green toads from Naxos (Cyclades) and Crete differ genetically from other populations and deserve genomic investigations (Dufresnes et al., 2019c). In summary, for Europe, we accept (1) Bufotes viridis, including the widespread $B . v$. viridis, B. v. balearicus (Italian Peninsula, Corsica, Sardinia, Sicily, Balearic islands) and B. v. sitibundus (within Europe restricted to a number of eastern Greek islands), (2) the Sicilian Bufotes boulengeri siculus and (3) Bufotes cypriensis. We note that the availability of the nomen siculus remains unclear, given that the corresponding description (Stöck et al., 2008) was only issued electronically and prior to 2011 (see Article 8.5 of the Code): whether "numerous identical and durable copies" (Article 8.1) were registered by the authors in parallel is yet to be addressed (see also Dubois et al., 2013).

Based on a high level of divergence in mitochondrial DNA sequences of Hyla tree frogs, Stöck et al. (2008) have suggested to recognise the Iberian taxon molleri and the eastern European taxon orientalis as species distinct from Hyla arborea. However, given the lack of other supporting characters (weak acoustic divergence: see Schneider, 1974; no wellsupported morphological characters), SBC2010 refrained from formally accepting this systematic treatment, as it would have rested solely on mitochondrial DNA data. Several more recent studies offer a better understanding of the phylogeny of this group and of the patterns of gene flow across contact zones. Firstly, Dufresnes et al. $(2015,2016)$ investigated the arborea-orientalis contact zones in Poland and in the Balkans with microsatellite markers. In Poland, they found evidence of admixture over a $200 \mathrm{~km}$ wide zone, with mosaic contacts and interspersed hybrid populations, but with strongly restricted introgression at sex-linked loci and many populations of seemingly pure ancestry in close contact to each other (Dufresnes et al., 2016). In the Balkans, Dufresnes et al. (2015) found narrow clines (30 and $32 \mathrm{~km}$ of average cline width in Serbia and Greece respectively). In line with our treatment of taxa connected by unimodal hybrid zones with narrow clines, we recommend affording species status to Hyla orientalis. Secondly, the phylogenomic tree in Dufresnes et al. (2018b) unambiguously groups orientalis and molleri as sister taxa, with arborea splitting from a node basal to the molleri - orientalis divergence. Therefore, we accept molleri at species rank as well. Although the close relationships between molleri and orientalis could justify to treat them as conspecific, we refrain for the time being from this arrangement. We thus treat Hyla molleri and Hyla orientalis as valid species.

Supported by mtDNA and genomic data, two major cryptic lineages reside within Hyla intermedia (Canestrelli, Verardi and Nascetti, 2007; Stöck et al., 2008; Dufresnes et al., 2018b). They are not known to differ in any diagnostic morphological or acoustic character, even if they differ in the averages of one acoustic and some morphometric traits. The northern lineage occupies the Po Plain and adjacent regions (including Ticino in Switzerland), with 
the northern Apennines acting as the biogeographical barrier separating it from the southern lineage. As the name intermedia applies to the southern lineage, Dufresnes et al. (2018b, c) coined a new name, Hyla perrini, for the northern lineage. Note that, as its registration in the Official Register of Zoological Nomenclature (ZooBank) occurred later than the publication of Dufresnes et al. (2018b), the name perrini is not made available by Dufresnes et al. (2018b), but by Dufresnes et al. (2018c), who met all conditions of nomenclatural availability. Detailed analyses of the contact zone based on genomic (RADseq) data by Dufresnes et al. (2018b) revealed broad clines (96 km of average cline width) for nuclear markers and detectable admixture over approximately $130 \mathrm{~km}$. Despite a relatively high cyt $b$ distance of around 9\%, and even though Dufresnes et al. (2018b) argued that the extent of the contact zone would be even larger without some form of selection against hybrids, the TC felt that the observed extent of introgression and thus the lack of strong reproductive barriers did not unambiguously allow treatment of perrini at species rank. We thus recommend to treat the northern lineage as Hyla intermedia perrini.

The authorship of the family Ranidae has been clarified by Dubois and Bour (2011), attributing it to Batsch, 1796.

Based on allozyme data (Arano, Esteban and Herrero, 1993; Veith et al., 2002, 2012), two genetically distinct groups have been recognised within Rana temporaria populations of northern Spain. The first was assigned to the subspecies $R$. $t$. parvipalmata and is restricted to the westernmost edges of the Iberian distribution (Galicia and Asturias). Frogs from western Galicia feature reduced feet webbing, smaller size and lower number of pulses per call (Vences, 1992). The second group corresponds to the nominal taxon $R$. $t$. temporaria, which extends throughout Europe. Mitochondrial data suggested a more complex picture, with four deeply differentiated lineages in the same area (Vences et al., 2013b, 2017). In a phylogeographic survey using genome-wide data, Dufresnes et al. (2020b) found one of these mitochondrial groups to be a "ghost lineage", not differentiated in the nuclear genome. The two main lineages are strongly differentiated and are estimated to have diverged around 4 Mya. Despite the absence of geographic or ecological barriers to dispersal, they form a narrow hybrid zone $(25 \mathrm{~km})$ in the eastern Cantabrian Mountains. Because partial reproductive isolation is thus likely to prevent these two taxa from merging, we follow the recommendation of Dufresnes et al. (2020b) to treat $R$. parvipalmata as a distinct species.

Using allozymes and mtDNA, a detailed analysis of gene flow patterns across the contact zone of the northern Anatolian lineage and the Balkan lineage of the Pelophylax ridibundus - bedriagae complex in northern Greece revealed the existence of a wide hybrid zone, with introgression detectable over more than $200 \mathrm{~km}$ (Hotz et al., 2013). This suggests that the European and Anatolian lineages are conspecific (contra SBC2010). Since the European lineage splits from a node basal to the diversification of Anatolian lineages with respect to mtDNA according to Plötner et al. (2012), it further suggests that most lineages of this complex are conspecific, with the possible exception of the populations from Syria and Jordan (possibly the 'true' bedriagae, see Plötner et al., 2012). On the other hand, Plötner et al. (2010) suggested hybrid breakdown between some of these lineages, indicating incipient speciation. While undoubtedly the last word on this subject has not been written, the TC felt that it was premature to suggest taxonomic changes, especially as a large taxonomic paper based on genomic variation patterns is in preparation (G. Mazepa, pers. comm.). The same applies to the newly proposed $P$. cypriensis, which was found to be placed between the European and the Anatolian lineages in mtDNA, but grouped with $P$. 
cretensis (albeit with very low support) in nuclear DNA (Plötner et al., 2012). For the moment, we thus suggest no change to the taxonomy adopted in SBC2010 for European Pelophylax.

\section{Reptilia}

\section{Testudines/Chelonii}

Based on nuclear genomic ISSR fingerprints and mtDNA sequences, Fritz et al. (2005) described Emys trinacris as a distinct species endemic to Sicily and Calabria, albeit the record from Calabria was later questioned (Vamberger et al., 2015). A phylogenetic study using seven nuclear genes (Spinks and Shaffer, 2009) found E. orbicularis to be paraphyletic with respect to trinacris: E. o. hellenica was sister to a clade containing trinacris and the remaining lineages of E. orbicularis. This led SBC2010 to conclude that trinacris should not be recognised as a species, which has been criticised by Vamberger and Fritz (2018). While trinacris is the most basal lineage in mtDNA trees (Fritz et al., 2005, 2007), this position is weakly supported, and the level of mtDNA divergence between trinacris and the other lineages is not clearly larger than that between some lineages of E. orbicularis. A first combined analysis of genetic differentiation at eight microsatellite loci and mtDNA sequences found concordant patterns for both markers: no evidence for admixture between Sicilian pond terrapins and the remaining lineages was found, while extensive admixture was found between some other lineages of $E$. orbicularis (Pedall et al., 2011). Using 15 microsatellite loci and mtDNA sequences, Vamberger et al. (2015) found evidence for limited admixture between the two taxa in one Sicilian population. In addition, Vamberger et al. (2015) reported concordant clines for both markers, with cline centres matching the Strait of Messina. Vamberger et al. (2015) argue that the coincidence of the cline centres with the Strait of Messina cannot be explained by a geographic barrier effect of this narrow sea strait, because in E. orbicularis recent gene flow occurred across the Strait of Gibraltar (Velo-Antón et al., 2015), and possibly across the Adriatic Sea between southern Italy and the Balkans (Vamberger et al., 2015). In contrast, Pereira, Teixeira and Velo-Antón (2018), using seven microsatellite loci, concluded that the Strait of Gibraltar currently impedes gene flow between Iberian and North African pond turtles. However, they show that the break between the two clusters corresponds to the Central Iberian Mountains and not the sea strait. Clines of microsatellites for the trinacris - orbicularis contact zone across the Strait of Messina were inferred to be very wide $(247 \mathrm{~km})$ in Vamberger et al. (2015), although the significance of this estimate is hampered by a substantial $(150 \mathrm{~km})$ sampling gap between the two taxa. The TC takes therefore a conservative stance and treats trinacris as a subspecies of E. orbicularis, waiting for further studies resolving the complicated relationships of this complex. In this context, we note that Pöschel et al. (2018) reported a sharp transition between occidentalis and orbicularis + galloitalica in north-eastern Spain, matching that of distinct species recognised here, suggesting that the E. orbicularis complex could comprise several species. In the meantime, we recommend to maintain the Sicilian lineage as Emys orbicularis trinacris.

\section{Squamata}

The family Agamidae is sometimes credited to Fitzinger, 1826 or Gray, 1827 (see e.g. Melville and Smith, 1987). In fact the nomen was first published by Spix in 1825 as "Familia Agamae". Even if Spix did not use the correct suffix '-idae', Article 11.7.1.3 of the Code states that "a family-group name of which the familygroup name suffix is incorrect is available with its original authorship and date, but with a corrected suffix". Other conditions of availability all seem to be fulfilled in Spix (1825), who is thus the author of the nomen. 
Macey et al. (2000a) sequenced a 1685-1778 bp long segment of mtDNA (including the ND1, ND2 and COI genes) to assess phylogenetic relationships of acrodont lizards. Their results suggested that the agamid genus Laudakia is paraphyletic, yet, low bootstrap support prevented definite conclusions. Subsequent studies based on mitochondrial and nuclear genes (ND2, RAG1) by Melville et al. (2009) and Edwards and Melville (2011) recovered Laudakia as monophyletic with high support. Baig et al. (2012) summarised the results of the aforementioned studies in a morphology-based revision of Laudakia. Despite failing to find distinct morphological variation within the genus, and acknowledging that Melville et al. (2009) and Edwards and Melville (2011) recovered Laudakia as monophyletic, Baig et al. (2012) partitioned Laudakia into three genera acknowledging its potential paraphyly (Macey et al., 2000a). This taxonomic act was subsequently criticised by Pyron, Burbrink and Wiens (2013), who confirmed the monophyly of Laudakia using a supermatrix approach. Within our focal area, the classification proposed by Baig et al. (2012) would affect Laudakia stellio and L. caucasia, as these authors placed the former species in the newly erected genus Stellagama, and the latter into Paralaudakia. While these genera were rapidly adopted by the wider herpetological community, we do not follow the split of Laudakia, pending substantial evidence to reject its monophyly, and therefore retain L. stellio and L. caucasia in Laudakia.

The family Chamaeleonidae is sometimes credited to Gray, 1825 (e.g. Glaw, 2015). However, Rafinesque (1815) published the name "Famille CAMÆLONIA", based on the genus "Camceleo Daud.", which is an incorrect subsequent spelling of the available genus Chamaeleo Laurenti, 1768. The Code is somewhat ambiguous regarding the availability of familygroup nomina based on an incorrect subsequent spelling of an available genus. Article 19.1 of the Code states that an incorrect subsequent spelling is not an available name. If one follows this and Art. 11.7.1.1 ("a family-group name when first published must [... ] be a noun in the nominative plural formed from the stem of an available generic name"), a family-group name based on an incorrect subsequent spelling of an available genus name is not available. Yet, the Code also states that "a family-group name is an incorrect original spelling and must be corrected if it is formed from an incorrect subsequent spelling of a generic name" (Art. 32.5.3.3) and that "a family-group name based upon [...] an incorrect spelling of the name of the type genus must be corrected" (Art. 35.4.1). It is thus clear that the Code has no intention to make a family-group name unavailable based on an incorrect spelling of the name of the type genus (see also Dubois, 2010). In conclusion, the family-group name Camaelonia is available as published by Rafinesque (1815), but its spelling needs to be corrected. The nowadays prevailing spelling Chamaeleonidae should be preserved (Art. 29.5), with its authorship attributed to Rafinesque (1815) instead of Gray (1825).

SBC2010 adopted the inclusion of Cyrtopodion kotschyi in the well-supported monophyletic genus Mediodactylus, as proposed by Macey et al. (2000b), Červenka, Frynta and Kratochvíl (2008) and Bauer et al. (2013). By enlarging the focal area of SBC2010, we hereby also include the former $C$. russowi, now Mediodactylus russowii. Another species occurring in the area considered by Gasc et al. (1997) but not in that of SBC2010 is the former Cyrtopodion caspium. We follow Bauer et al. (2013) in recognising the well-resolved genus Tenuidactylus and list this species as Tenuidactylus caspius. Furthermore, an introduced, well-established population of Tenuidactylus fedtschenkoi has recently been reported from the city of Odessa (Ukraine). The native range of $T$. fedtschenkoi lies in central Asia (western Pamiro-Altay mountains), and it was probably transported passively to Odessa (Duz', Kukushkin and Nazarov, 2012). Not long 
after the record from Odessa, a revision of the genus Tenuidactylus led to the description of a new species from Uzbekistan and Turkmenistan, which was split from T. fedtschenkoi and named T. bogdanovi (Nazarov and Poyarkov, 2013). Krasylenko and Kukushkin (2017) provided an update on the status of the non-native Odessa population and assigned it to T. bogdanovi.

Within Mediodactylus kotschyi, many subspecies have traditionally been recognised. As indicated by Kasapidis et al. (2005), the genetic substructure of Mediodactylus kotschyi shows a high degree of divergence, suggesting that $M$. kotschyi represents a species complex. Nearly range-wide data (with limited areas in eastern and northern Anatolia excluded) of three mtDNA and three nuclear DNA fragments allowed unravelling the evolutionary history of Mediodactylus kotschyi (Kotsakiozi et al., 2018). Divergence dates back to 15 Mya, and several of the main lineages show overlapping distribution areas. Divergence in mtDNA is known to be often quite large in geckos (e.g. Nagy et al., 2012). However, distances between the main lineages are particularly large in this case $(>10 \% \quad 16 \mathrm{~S}$ and $>15 \%$ cyt $b$ and COI $p$-distances). In addition, nuclear data groups specimens in concordance with their mtDNA lineage, and not with their geographical origin, which suggests a high level of reproductive isolation between them. The proposed splits also largely agree with morphological data (Štěpánek, 1937, 1939; Szczerbak and Golubev, 1996). The narrow contact between $M$. orientalis and $M$. danilewskii in the Western Taurus Mountains, identified by Kotsakiozi et al. (2018), corresponds to a lack of morphological intergrades (despite the narrow gap between the subspecies danilewskii and ciliciensis in the same area, see Rösler, Schmidtler and Moravec, 2012), while these new species are very close to the $M$. kotschyi groups defined by Beutler (1981). Five species were recognised, for all of which previously existing names are available (Kotsakiozi et al., 2018). While the delimitation of the ranges and contact zones of these new species requires further investigation (e.g. M. danilewskii and M. orientalis), we accept these species here. The following species are thus recognised in our area: $M$. kotschyi (mainland Balkans, most of Aegean islands, and Italy (Apulia)), M. bartoni (Crete and nearby islets), M. danilewskii (Black Sea region and south-western Anatolia), M. oertzeni (southern Dodecanese Islands), and $M$. orientalis (Levant, Cyprus, southern Anatolia, and south-eastern Aegean islands).

The endemic gecko from the Selvagens Islands has variously been treated as the valid species Tarentola bischoffi (e.g. Rebelo, 2008; Sindaco and Jeremčenko, 2008; Uetz, Freed and Hošek, 2019), or as a subspecies of the Canarian T. boettgeri as T. boettgeri bischoffi (e.g. Carranza et al., 2000; Pleguezuelos, Márquez and Lizana, 2002; Gübitz, Thorpe and Malhotra, 2005; Sá-Sousa et al., 2009). Its phylogenetic affinities were examined by Carranza et al. (2000, 2002) and Gübitz, Thorpe and Malhotra (2005). The genetic data available (albeit based only on mtDNA) show that the mitochondrial lineages of bischoffi are closely related to those of T. boettgeri, especially to the subspecies T. b. hierrensis from El Hierro, and are in fact nested inside the mitochondrial diversity of $T$. $b$. boettgeri from Gran Canaria, suggesting that the Selvagens Islands were recently colonised from El Hierro or Gran Canaria (Carranza et al., 2000, 2002; Gübitz, Thorpe and Malhotra, 2005). Treating bischoffi as a valid species, while retaining hierrensis as a subspecies of boettgeri (as done by the above authors who rank bischoffi as a species), is thus likely to render Tarentola boettgeri paraphyletic. The amount of mitochondrial divergence between hierrensis and bischoffi is also smaller than within the populations of $T$. $d e$ lalandii from Tenerife or between the populations of T. angustimentalis from Fuerteventura and Lanzarote. Based on the available data, we thus recommend to treat the geckos from the 
Selvagens Islands as conspecific with the populations from El Hierro and Gran Canaria, as Tarentola boettgeri bischoffi.

Sánchez-Vialas et al. (2018) re-examined the description of Algyroides hidalgoi Boscá, 1916, a nomen for which the holotype has been lost, to settle its position in the synonymy of the genus Algyroides. They argued that the characters of the holotype, said to originate from the Sierra de Guadarrama and described by Boscá, fall within the morphological variability of $A l$ gyroides marchi Valverde, 1958, and designated a specimen of $A$. marchi as neotype of $A$. $h i$ dalgoi. This would make A. marchi a junior subjective synonym of $A$. hidalgoi. Because the conditions for automated reversal of precedence are not met (Art. 23.9.1 of the Code), A. hidalgoi would become the valid nomen of the Spanish Algyroides. Several TC members felt, however, that the interpretation of the description of Boscá (1916) by Sánchez-Vialas et al. (2018) left room for doubt, and that Boscá may not have described a specimen of Spanish Algyroides when he created the name Algyroides hidalgoi. If so, this could affect the validity of the neotype designation, respective to Art. 75.3.5 of the Code, and result in the unnecessary change of the well-established and widely used name $A$. marchi. Although opinions in the TC were divided about this, we recommend to maintain for the time being the use of $A$. marchi, in anticipation of an upcoming application to the Commission, which would maintain marchi in use until the Commission has ruled on the case.

Morphological and molecular (mtDNA and nuclear) data support the split of Psammodromus hispanicus into three distinct lineages (Fitze et al., 2011, 2012; Mendes et al., 2017). While not all areas of potential contact have been sampled (despite a recent distribution update by Molina et al., in press), the available data seem to warrant accepting these lineages as distinct species. Age estimates, lineage allopatry, the lack of mitochondrial and nuclear haplotype sharing between lineages, bioclimatic niche divergence, and the current biogeographic distribution, indicate that the three lineages correspond to three independent species. The name of the eastern species is often spelled $P$. edwardsianus. As shown by Crochet (2015), this is an incorrect subsequent emendation that does not meet the requirements of the Code. As a consequence, the valid spelling of the eastern species is Psammodromus edwarsianus. Thus, we add Psammodromus edwarsianus and $P$. occidentalis to the list of the European herpetofauna species.

A 9 Mya split marks the divergence of Timon lepidus nevadensis from the nominal subspecies T. l. lepidus (Miraldo et al., 2013). After studies on genetic (Paulo et al., 2008; Miraldo et al., 2011, 2013) and morphological differentiation (Mateo and Castroviejo, 1990; Mateo, LópezJurado and Guillaume, 1996), mtDNA and microsatellites were used to investigate gene flow patterns in a zone of secondary contact (Miraldo et al., 2013). While hybridisation and introgression were observed, gene flow was shown to be restricted. The cline width for nuclear markers was estimated at around $10 \mathrm{~km}$ (although with a sampling gap of around $20 \mathrm{~km}$, it may actually be less). Furthermore, mostly pure populations are present on either side of the sampling gap. Considering this together with the aforementioned old genetic divergence, we accept the proposal of Miraldo et al. (2013) and treat $T$. nevadensis as a valid species.

Lacking range-wide sampling and adequate molecular analysis, the taxonomy of the Lacerta trilineata-pamphylica complex has remained unresolved, until mitochondrial phylogenies showed the eastern Anatolian species $L$. pamphylica to be nested within trilineata (Godinho et al., 2005; Ahmadzadeh et al., 2013; Sagonas et al., 2014). Remarkably, Sagonas et al. (2014) found evidence that central Aegean populations (L. t. citrovittata) are closely related to L. pamphylica. Yet, this was poorly supported across analyses and the biogeographically surprising relationship between $L$. $t$. citrovittata and L. pamphylica could reflect a methodological artefact (long branch attraction). Thus, the 
monophyly of $L$. trilineata could not be rejected. More recently, analyses of SNPs and mitochondrial sequences by Kornilios et al. (2019, 2020) found a sister-group relationship between pamphylica and eastern Aegean populations of trilineata. This led to the identification of four species-level units: L. trilineata (eastern Adriatic Coast, Greece except northeast and including Milos archipelago and Crete, south-eastern Bulgaria and North Macedonia), L. pamphylica (southern Anatolia east of Antalya), L. citrovittata (central Aegean islands, including among others Naxos, Tinos, Andros, Syros, Mykonos, Paros), and L. diplochondrodes (north-eastern Greece, Romania, Bulgaria except southeast, Turkey, eastern Aegean Greek islands). All evidence (morphology, blood biochemistry, immunoserology, congruence between highly divergent mtDNA and nuclear genomics, bioclimatic niche differences, no signs of admixture) suggests that L. pamphylica deserves species status. As the eastern Aegean populations of the complex are the sister taxon of L. pamphylica, maintaining monophyly implies also treating them as a species, L. diplochondrodes. The latter taxon does not show a lot of contact, nor signs of introgression with any of the other three clades. Concerning the population west of the Aegean Barrier, the conclusion may seem less straightforward. However, genomic analyses offer stronger support for the species status of $L$. citrovittata than for that of L. pamphylica. The former equally corresponds to one of the major mtDNA lineages of Kornilios et al. (2019). Given its allopatry, there is no evidence of admixture. While the (potential) contact zone between $L$. diplochondrodes and L. trilineata in north-eastern Greece and its wider surroundings requires more comprehensive sampling, we suggest to accept the new four species arrangement and to recognise Lacerta trilineata, L. diplochondrodes, L. citrovittata, as well as the extralimital L. pamphylica.

Using one mitochondrial and one nuclear gene, Marzahn et al. (2016) investigated the phylogeography of the Lacerta viridis complex. Four main mtDNA lineages, whose phylogenetic relationships were weakly resolved, emerged from the data: (i) Lacerta bilineata, (ii) Lacerta viridis s.s., (iii) an Adriatic and western Balkan lineage, and (iv) a newly discovered lineage from the south-eastern Balkans as well as the Turkish Black Sea Coast. A previously supposed (Amann et al., 1997) contact zone between $L$. bilineata and $L$. viridis in north-eastern Italy was found to be in fact a contact zone between the Adriatic and western Balkan lineage and L. bilineata. Another contact zone between the Adriatic and western Balkan lineage and $L$. viridis s.s. lies further east in Slovenia and adjacent Croatia. As a consequence, there is no known geographical contact zone between $L$. viridis s.s. and L. bilineata. Several other contact zones between mitochondrial lineages were identified across the distribution range. However, the nuclear data were insufficient to examine gene flow among lineages. Consequently, no species-level changes were suggested. The previously reported occurrence of L. bilineata on Cres, Croatia (Brückner et al., 2001), was confirmed. However, this record is isolated from the remaining distribution range and lies among surrounding records of the Adriatic and western Balkan lineage (Marzahn et al., 2016), suggestive of an introduced population.

Speybroeck and Crochet (2007) and SBC2010 adopted the split of the former genus Lacerta s.l., accepting all genus names recognised by Arnold, Arribas and Carranza (2007), as far as they pertained to taxa occurring within their considered area. As we have adopted a broader area definition here, we additionally formally accept the genera Anatololacerta and Phoenicolacerta. The latter only has a single representative within our area, the Cypriot $P$. troodica. Within our area, the genus Anatololacerta can be found on several Greek islands, including Ikaria, Samos, Rhodes, Pentanisos and Kastellorizo. Based on morphology, Eiselt and 
Schmidtler (1986) treated A. anatolica (including the subspecies aegaea from Samos), A. danfordi and A. oertzeni (including the subspecies A. o. pelasgiana on Rhodes, Symi and Pentanisos and the nominotypical subspecies on Ikaria) as valid species. However, because the biochemical differentiation (based on albumins) between them was deemed to be too small, Sindaco and Jermenčenko (2008) maintained all populations within Anatololacerta danfordi, following Mayer and Lutz (1989). Bellati et al. (2015) combined multi-locus species tree approaches with species delimitation methods to suggest the recognition of four distinct species in this group. Some of these species are closely related and were inferred to have diverged as recently as 500,000 years ago, i.e. a remarkably young age for speciation events within Lacertidae. Yet, there seems to be evidence of reproductive isolation between some of these species, as shown by the patterns of allele sharing in some nuclear markers. While more detailed analyses of patterns of gene flow in contact zones would be desirable, we tentatively accept the four-species taxonomy (A. anatolica, $A$. budaki, A. danfordi and A. pelasgiana) of Bellati et al. (2015). In our area, A. anatolica is present on Ikaria and Samos, and A. pelasgiana on Symi, Pentanisos and Rhodes. In addition, $A$. pelasgiana was also found (although presumed introduced in both cases) on Kasos (Kornilios and Thanou, 2016) and Kastellorizo (Kalaentzis et al., 2018), while A. budaki was found on the (nearby) islet Psomi (Kalaentzis et al., 2018).

As pointed out by Busack et al. (2016), the microfiche publication of Arribas's (1997) thesis does not meet the criteria of publication for valid zoological nomenclature, neither under the current version of the Code nor under the previous (and then relevant) version. As a consequence, the names Iberolacerta and Darevskia were not made available in Arribas (1997). For Iberolacerta, this has no major nomenclatural consequences, as the next available nomen is Iberolacerta Arribas, 1999. However, because Darevskia Arribas, 1999 is a junior synonym of Caucasilacerta Harris, Arnold and Thomas, 1998, Busack et al. (2016) conclude that Caucasilacerta must replace Darevskia as the valid nomen for the genus of the Caucasian Rock Lizards. The conclusions drawn by Busack et al. (2016) prompted a number of responses (Arribas, 2016; Arribas et al., 2017), advocating that $\mathrm{Cau}$ casilacerta is a nomen nudum and hence is unavailable. Subsequently, Arribas et al. (2018) appealed to the ICZN (under Articles 78.1 and 81 of the Code) to accept Arribas (1997) as published in the sense of the Code and preserve Darevskia Arribas, 1997 and Iberolacerta Arribas, 1997. While we regard Caucasilacerta as available, we support the current application to preserve Darevskia. We note that, while the case is under consideration by the Commission, the prevailing usage of Darevskia and Iberolacerta with their authorship as Arribas, 1997 is to be maintained (Article 82).

Based on morphological variation, Stugren (1961) advocated the recognition of three subspecies of Darevskia praticola: the nominotypical subspecies in the east of the distribution (central and eastern Caucasus, northern and south-eastern Georgia, northern Armenia, southern Azerbaijan, and north-eastern Iran), the subspecies pontica in the west of the Caucasus and in western Georgia, and D. p. hungarica in Europe (north-eastern Serbia, southern Romania, north-eastern Greece, eastern and western Bulgaria). Later, he recommended to treat $D$. p. hungarica as a synonym of D. p. pontica, resulting in a two-subspecies classification (Stugren, 1984). On the basis of multivariate analysis of morphological, meristic and qualitative characters of Balkan and Caucasus populations, Ljubisavljevic et al. (2006) confirmed the validity of the two subspecies $D$. p praticola and D. p. pontica. Tuniyev et al. (2011) presented a detailed morphological study for the populations of the Caucasian Isthmus. They confirmed two morphological clusters in the Caucasus and 
Transcaucasia (western Caucasus: D. p. pontica; eastern Caucasus + Transcaucasia: D. $p$. praticola), and described a new subspecies from the Talysh Mountains (the extralimital D. p. hyrcanica). On the basis of morphological differentiation and unpublished genetic data, they also advocated species status for D. p. pontica. Later, Freitas et al. (2016) provided a phylogeographic study of the species, based on comprehensive sampling covering most of the range (although the central and eastern Caucasus parts of the range were missing). They recovered two clades in the Caucasus and in Transcaucasia, one in the western Caucasus (corresponding with the Caucasian range of the $D$. $p$. pontica subspecies) and one in Transcaucasia (Armenia) and the Talysh Mountains, corresponding with the extralimital subspecies D. p. hyrcanica and Tuniyev's et al. (2013) D. p. loriensis. Samples of the nominotypical subspecies were not included, although their morphology suggests that they would presumably group with the Transcaucasian samples (see Tuniyev et al., 2011, 2013). Freitas et al.'s (2016) results thus seem to support the divergence of two lineages in the Caucasus, corresponding to Caucasian populations of pontica on the one hand, and populations of the praticola phenotype (including loriensis and hyrcanica) on the other hand. However, genetic analyses of samples of praticola from the eastern Caucasus would be needed to confirm this. More surprisingly, Freitas et al. (2016) also uncovered a deep split within populations traditionally classified as pontica, with the European samples from the Balkans forming a deeply divergent lineage in both mtDNA and nuclear DNA that splits from a node basal to the clade grouping the Caucasian and Transcaucasian samples. They estimated the divergence between the European and Caucasian + Transcaucasian clades at around 2.5 Mya, with a much younger split of the Transcaucasian lineage around 650,000 year ago. As pointed out by Ljubisavljevic et al. (2006), the name D. $p$. hungarica (Sobolevsky, 1930), with type locality in the Transylvanian Alps (which at the time was part of the Kingdom of Hungary, including parts of today's Romania), should be applied to the Balkan lineage. Given the incomplete geographic coverage of Freitas et al. (2016) and the somewhat borderline level of genetic divergence between the Balkans and Caucasian + Transcaucasian lineages, we refrain from recommending species status for the time being, and thus suggest to treat the Balkan populations as Darevskia praticola hungarica. We further disagree with the conclusion of Freitas et al. (2016) to treat D. p. pontica as a synonym of D. p. praticola, as all their samples correspond with the range of $D$. p. pontica according to Tuniyev et al. (2011), and they have therefore not analysed any sample from the range of D. p. praticola. Conclusively, we maintain the morphologically well-supported subspecies D. p. pontica and D. p. praticola for the Caucasian populations occurring in our area, while the Balkan populations are referred to as the subspecies D. p. hungarica.

Genetic relationships based on a mtDNA (cyt b) fragment suggest that Darevskia brauneri szczerbaki is sister to $D$. saxicola rather than grouping with other lineages of $D$. brauneri (Doronin, Tuniyev and Kukushkin, 2013; Tarkhnishvili et al., 2016). Based on this and on analysis of morphological variation coupled with differences in ecology, Tuniyev and Tuniyev (2012) and Doronin, Tuniyev and Kukushkin (2013) suggested to treat szczerbaki as a valid, monotypic species. However, this hypothesis is in conflict with the results of MacCulloch et al. (2000), who found a lack of fixed differences in 15 polymorphic allozyme loci between D. b. brauneri, D. b. darevskii and $D$. b. szczerbaki, and concluded that these three taxa are conspecific. The high incidence of hybridisation within Caucasian Darevskia makes mtDNA relationships potentially unreliable. In addition, because of the low level of cyt $b$ divergence $(2.4 \%$ between $D$. saxicola and $D . b$. szczerbaki, and $4.8-5.6 \%$ of both D. saxicola and $D . b$. szczerbaki towards other $D$. brauneri sequences) and the conflict with allozyme data, 
we consider this species complex to be currently too poorly studied to recognise additional species without extensive evidence from nuclear genes and/or strong morphological differentiation in sympatry or close parapatry. As both of these lines of evidence are still lacking in this case, we maintain $D$. b. szczerbaki at subspecies rank for the time being.

Two parthenogenetic Darevskia species which are not native to our area have been introduced near Zhytomyr, Ukraine (Nekrasova and Kostiushyn, 2016). Darevskia armeniaca occurs naturally in north-western Armenia, western Azerbaijan, southern Georgia and northeastern Turkey, and is believed to have been introduced in 1963, whereas D. dahli, known from northern Armenia and southern Georgia, was discovered more recently (1980) within the introduced armeniaca population. A third species, D. mixta, was also introduced in 1968 , but its contemporary presence could not be confirmed (Nekrasova and Kostiushyn, 2016).

Mayer et al. (2000) described the oviparous Zootoca vivipara populations of Carinthia (Austria), Slovenia, Friuli and isolated sites across the Po Plain (Italy) as the distinct and allopatric subspecies Z. v. carniolica. Additional molecular analysis confirmed its validity (Surget-Groba et al., 2001, 2002). More recently, this taxon was shown to inhabit a wider range than previously known, not only occupying parts of southern Austria, Slovenia, northern Croatia and north-eastern Italy, but actually extending west as far as the central southern Italian Alps (Cornetti et al., 2015a). Lindtke, Mayer and Böhme (2010) documented a narrow contact zone in Carinthia (Austria), and detected two natural hybrids (identified by clutch features) in a sample of 36 specimens. As they did not use genetic markers, they could not investigate the level of introgression. More recently, two studies by Cornetti et al. (2015a, b) demonstrated complete reproductive isolation between carniolica and vivipara, in spite of widespread close parapatry between these two taxa. Cornetti et al. (2015a) focused on the contact zone with local syntopy in northern Italy, and did not detect any hybrid or admixed genotype out of around 30 individuals (genotyped with 13 microsatellites). Cornetti et al. (2015b) genotyped many more individuals from several regions in the northern Italian Alps where the two taxa come in close parapatry, and found a similar lack of admixture. Thus, carniolica and vivipara appear to represent two different species, and we accept Zootoca carniolica at species level.

After being placed into the genus Lacerta, Teira dugesii and Scelarcis perspicillata were transferred to the subgenus Teira and the genus Podarcis, respectively, based on morphology (Richter, 1980). Subsequently, Teira was elevated to genus level by Mayer and Bischoff (1996). Yet, the generic allocation of S. perspicillata and $T$. dugesii remained a matter of confusion, with several authors attributing both species to the genus Lacerta until quite recently (e.g. Brehm et al., 2003; Perera et al., 2007). Even though Pavlicev and Mayer (2009) suggested treating Scelarcis as a junior synonym of Teira and placing both species into the genus Teira, SBC2010 adopted the genus arrangement of Arnold, Arribas and Carranza (2007) and assigned the Moroccan Rock Lizard to Scelarcis as Scelarcis perspicillata. However, a recent study using data from anchored phylogenomics and a fossil-dated time tree by Garcia-Porta et al. (2019) confirmed that Teira and Scelarcis are sister taxa and that their divergence is at a similar level or even lower than among species of many well-established genera. According to this study, Teira and Scelarcis diverged from each other in the mid-Miocene, coinciding with or even post-dating intrageneric splits in many other lacertid genera such as Algyroides, Gallotia, Iberolacerta, Lacerta, Podarcis, Psammodromus, Takydromus, and Timon. Mendes et al. (2016) argued to maintain Scelarcis mainly because of nomenclatural stability. We follow this approach and maintain Teira and Scelarcis as valid genera, awaiting additional evidence. 
Psonis et al. (2017, 2018) examined species delimitation in the Podarcis tauricus group (including $P$. tauricus, $P$. milensis, $P$. gaigeae and $P$. melisellensis) using mitochondrial and nuclear DNA sequences, microsatellites and RADseq data. Their most complete phylogenomic analysis offered a fully resolved species level phylogeny, and confirmed the existence of extensive genetic structuring within P. tauricus. Two main clades correspond with the western and eastern part of the distribution of the species on either side of the Pindos Mountains. The level of divergence between them is comparable with their divergence from the wellestablished species $P$. melisellensis, P. milensis and $P$. gaigeae, and extensive admixture is not apparent from the available data. They differ quite obviously in coloration of adult males. Even if no information on the nature of the contact zones is available, the data at hand support the split of $P$. tauricus into an eastern species (retaining the name $P$. tauricus and including the subspecies $P$. $t$. thasopulae) and a western species, for which the oldest available name is P. ionicus (Psonis et al., 2017, 2018). Several of the subclades within P. ionicus, supported by mitochondrial and genomic data, are as divergent as other species pairs in the genus Podarcis and probably warrant species status as well, but formal recognition as separate species is still lacking. On the basis of published information, we accept the split of Podarcis tauricus into two species: $P$. tauricus and $P$. ionicus.

Using published data on three mitochondrial and three nuclear genes, Senczuk et al. (2019) examined the phylogeny of the genus Podarcis to address the systematic status of the Podarcis siculus populations from the Western Pontine Islands, off the Italian west coast. They estimated that the Western Pontine lineage diverged from all other $P$. siculus lineages around 4 Mya, and showed that this genetic divergence is similar to or greater than that between many other species pairs of Podarcis lizards. Hence, they formally raised the Western Pontine populations, currently classified as several subspecies of $P$. siculus, to species rank as Podarcis latastei, as latastei is the oldest name available for this lineage. At this stage we are reluctant to follow this decision for two reasons. Firstly, the amount of divergence between the Western Pontine populations and the rest of the $P$. siculus complex in Senczuk et al. (2019) is only presented as a combined mtDNA and nuclear DNA tree, not allowing to check if nuclear data independently supports this species-level divergence or not. As multiple examples of deep mtDNA divergence that are not reflected in genomic divergence are known, we feel that compelling evidence of nuclear DNA divergence is needed before adopting this new species. Secondly, Senczuk et al. (2019) presented a simplified picture of the patterns of genetic divergence in $P$. siculus. More detailed results by Senczuk et al. $(2017,2018)$ display a much more complex situation, where the Western Pontine lineage appears as one of several deeply divergent lineages in P. siculus, and latastei and siculus are not reciprocally monophyletic. While Senczuk et al. (2018) indicated differentiation in nuclear DNA between at least some of the main mtDNA lineages in $P$. siculus, no information on their level of reproductive isolation is yet available. As a consequence, while the TC acknowledges that $P$. siculus as currently understood is possibly made up of several species, one of them corresponding to the Western Pontine islands populations, we consider adopting any formal taxonomic change premature.

Michels and Bauer (2004) provided a list of what they argued to be justified emendations (citing Article 31.1.2 of the Code) of non-avian reptile and amphibian scientific names which the authors identified as inappropriate original constructions of patronyms or matronyms. Among the listed species was Podarcis raffonei (as Lacerta sicula raffonei Mertens, 1952). Because this taxon was named in honour of the collectors' wife, Michels and Bauer (2004) concluded that raffonei should be changed into raffoneae. However, Article 31.1.2 simply states 
how species-group names should originally be formed. The article does not provide grounds for subsequent changes to the name. Furthermore, justified emendations can only be made to 'spellings that must be corrected' (Article 32.5, see also 33.2.2), in which these cases are not included. Even though Michels and Bauer (2004) are linguistically correct (Arribas, 2017), amending raffonei to raffoneae is unjustified (Article 33.2.3), making the latter an unjustified emendation and hence a junior objective synonym of the former (see also Dubois, 2007). We thus recommend to maintain the original spelling $P$. raffonei. As a side note, we highlight that the results of Senczuk et al. (2019) also cast serious doubts on the validity of the species status of $P$. raffonei, but we refrain here from advocating any change for now.

Investigating the species group comprising Podarcis cretensis, P. levendis and P. peloponnesiacus, Spilani et al. (2019) found wellsupported differentiation within the latter species. Based on 17 microsatellites, the eastern populations diverged 1.86 Mya. Most noteworthy, the eastern and western lineages occur in actual or near syntopy without any apparent sign of admixture. The observed level of divergence, together with evidence of reproductive isolation, warrant a species-level split within $P$. peloponnesiacus. However, Spilani et al. (2019) refrain from making any taxonomic change. The TC follows this position, as we await a forthcoming morphological study, prior to proposing a formal change.

From a long line of studies on the Iberian Podarcis species, the acceptance of Podarcis liolepis and the redefinition of Podarcis hispanicus sensu stricto were the most recent steps that were adopted by SBC2010. At the time, two additional species were sufficiently substantiated, genetically as well as morphologically. Awaiting formal naming, they were listed as Podarcis hispanicus type 1 (north-western Iberian Peninsula and central Iberian mountain chains) and type 2 (parts of central and south-western Iberian Peninsula). Geniez et al.
(2014) provided additional morphological analyses, and formally named them as Podarcis guadarramae (former type 1) and $P$. virescens (former type 2). Morphological and molecular differentiation within Podarcis guadarramae resulted in the description of the subspecies $P$. $g$. lusitanicus from northern Portugal and northwestern Spain. We accept $P$. guadarramae and $P$. virescens as valid species, while the status of lusitanicus will be the focus of a forthcoming study (G. Dias and C. Pinho, pers. comm.).

Although sometimes credited to Gray, 1825 (e.g. Sindaco and Jeremčenko, 2008), the family name Scincidae must be credited to Oppel (1811), as adopted by Hedges (2014) and others. Oppel (1811) created the name as "Familia. Scincoides". Article 11.7.3 of the Code (see family Agamidae above) makes it clear that the nomen is made available by its publication in Oppel (1811), even if the suffix must be corrected.

A split of the Scincidae into seven families would affect the systematics of the European genera, with Ablepharus being placed into $\mathrm{Eu}-$ gongylidae, Heremites into Mabuyidae and the remaining genera Chalcides, Ophiomorus and Eumeces remaining in Scincidae s.s. (Hedges and Conn, 2012; Hedges, 2014). This was neither adopted in the large-scale squamate phylogeny of Zheng and Wiens (2016), nor in the online Reptile Database (Uetz, Freed and Hošek, 2019). As most skinks are readily recognisable as belonging to this group, and the monophyly of Scincidae sensu lato is well established, we follow the argument of the 'phenotypic diagnosability' taxon naming criterion of Vences et al. (2013a) for the time being, keeping all species (even if there are many) within a single family. Distinction of subfamilies, however, certainly makes sense as it provides more manageable units for taxonomic revision and other purposes.

For a long time, the skink genus Mabuya included numerous species from South America, Africa and Asia. A series of phylogenetic works (e.g. Mausfeld et al., 2000, 2002; Carranza and Downloaded from Brill.com04/26/2023 02:26:09PM 
Arnold, 2003; Mausfeld and Schmitz, 2003; Whiting et al., 2006) confirmed the monophyly of the genus, but also uncovered deep evolutionary divergence between its main radiations, which also differ consistently in several morphological and life-history traits. The initial divergence within the group is estimated to date back to the Eocene, between 40 and 50 million years ago (Karin et al., 2016). Mausfeld et al. (2002) were the first to suggest a split of the genus Mabuya to reflect the long evolutionary divergence of its main lineages, a proposal that has been universally adopted since. The Middle Eastern Mabuya species (M. aurata, M. septemtaeniata and $M$. vittata) form a well-supported monophyletic group in all phylogenies. They have been classified with the African species in the genus Trachylepis for several years but, even if their phylogenetic position within the radiation of the former Mabuya is still poorly resolved, they are not part of the radiation of African species in the genus Trachylepis (Karin et al., 2016). Their origin is quite ancient (estimated around the late Oligocene, more than 30 million years ago) and their clade is thus now afforded genus rank by all recent works on the subject, a position that we follow here. The valid genus-group nomen of the Middle-East clade is Heremites Gray, 1845 (masculine, see Karin et al., 2016). We thus recommend calling the Middle East species Heremites auratus, $H$. vittatus and the extralimital $H$. septemtaeniatus.

The phylogeography of Ophiomorus punctatissimus was examined by Poulakakis et al. (2008) using three mitochondrial fragments. On the basis of divergence rates of mitochondrial genes calibrated in other groups of squamates, they uncovered a deep divergence between the Asian (Anatolian) and European populations of the species, estimated to have occurred around 10 Mya. This date fits nicely with the opening of the mid-Aegean trench, estimated from geological information to have started around 12 Mya and being completed around 9 Mya. More recently, Kornilios et al. (2018) used mtDNA and nuclear DNA data (three nuclear genes) for single-locus and multilocus coalescent-based species delimitation. The established COI $p$-distance is substantial (12.7\%). No allele sharing was found, and the Asian and European lineages appeared reciprocally monophyletic for all three nuclear genes, confirming their long-term isolation. Even if suboptimal preservation of specimens and/or morphological conservatism in these fossorial species did not allow identifying any morphological differentiation between the two allopatric Ophiomorus lineages, the authors advocated recognition of the eastern lineage from Anatolia as a new species, which they described as $O$. kardesi. The status of several mitochondrial lineages recovered within $O$. punctatissimus awaits further study. Based on the divergence time and level of genetic divergence between these two cryptic species, we accept the species status of $O$. kardesi. In our area, the new species occurs on the Greek island of Kastellorizo (Kornilios et al., 2018).

Phylogenetic analysis based on mitochondrial and nuclear markers (Skourtanioti et al., 2016) showed strong divergence, supporting the independent history of a clade of snakeeyed skinks (Ablepharus) from Kastellorizo and southwestern Turkey. The samples of this clade originate from an area where the only taxon known to occur according to Schmidtler (1997) is Ablepharus budaki anatolicus. As a consequence, Skourtanioti et al. (2016) suggested that the name anatolicus is available for this new species-level lineage, which splits from a more basal node than all other but one (A. pannonicus from Iran) species of the genus, and whose divergence was estimated to date back to the mid-Miocene. As the genetic differentiation and deep phylogenetic divergence of the new species was confirmed by independent analyses of both mitochondrial and nuclear genes, we agree that the genetic data strongly support the recognition of an additional Ablepharus species from SW Turkey (including Kastellorizo and hence entering our area). However, we refrain from formally accepting a new species here and Downloaded from Brill,com04/26/2023 02:26:09PM 
prefer to wait until genetic data confirm that animals from the type locality of anatolicus indeed represent this new lineage.

Sindaco and Jeremčenko (2008), who provided the starting point of our taxonomy for areas not covered by SBC2010 or Gasc et al. (1997), follow Pasteur, Keymar and Perret (1988) in treating the Gran Canaria skinks as two species, Chalcides bistriatus in the northeast of the island and $C$. sexlineatus in the southwest. This classification was based on a sharp geographic transition in morphology and (especially) colour pattern between the skinks inhabiting the mesic and xeric habitats on Gran Canaria (see Brown and Thorpe, 1991a, b, although these authors rejected the hypothesis of speciation between these morphotypes). Studies on the evolutionary history of these populations using allozymes (Mayer and Tiedemann, 1991) or a combination of mtDNA and microsatellites (Suárez, Pestano and Brown, 2014) established that this differentiation has a genetic basis, originating from allopatric diversification within Gran Canaria. This divergence is linked to volcanic activity 1.5-3 Mya and is currently maintained by strong selection on coloration, in spite of considerable introgression and gene flow between the two morphs. While the deepest divergence between the mtDNA clades within Gran Canaria is dated to $1.5 \mathrm{Mya}$, the divergence between the two morphs was dated to 260,000 years ago. This discrepancy could reflect real differences between coalescence time of mtDNA lineages versus divergence time of populations, or analytical issues with one of the methods. Either way, the available data suggest a young divergence of $C$. s. sexlineatus and $C$. $s$. bistriatus, together with a lack of reproductive isolation. We thus recommend to treat these taxa as conspecific as $C$. $s$. sexlineatus and $C$. $s$. bistriatus, as adopted by Mayer and Tiedemann (1991), Carranza et al. (2008) and Salvador and Brown (2015).

Mitochondrial DNA data of the Canarian skinks establish with a very high support that the Chalcides from Tenerife (C. v. viridanus) and La Gomera and El Hierro (C. v. coeruleopunctatus) are not each other's closest relative, with coeruleopunctatus being more closely related to the taxa from Gran Canaria (sexlineatus and bistriatus) than to viridanus (Brown and Pestano, 1998; Carranza et al., 2008). These relationships rule out maintaining coeruleopunctatus as a subspecies of viridanus, as was traditionally the case based on their morphological similarity. In addition, the amount of divergence between $C$. sexlineatus, $C$. viridanus and $C$. coeruleopunctatus is typical of interspecific divergences in the genus Chalcides (Carranza et al., 2008). We thus accept the conclusion of Carranza et al. (2008) and treat the animals from La Gomera and El Hierro as Chalcides coeruleopunctatus.

The publication dates of the works of Daudin have been worked out by Harper (1940). The volume 4 of "Histoire Naturelle des Reptiles", containing the description of Eumeces schneiderii, was published in August 1802. The specific epithet is often spelled schneideri, even if both schneideri and schneiderii are in use. The original spelling is schneiderii (see Daudin, 1802), with schneideri as an incorrect subsequent spelling. The only reason to use this spelling rather than the original spelling would be if the incorrect subsequent spelling schneideri was in prevailing usage (see Art. 33.3.1 of the Code). Prevailing usage is defined by the Code as "that usage of the name which is adopted by at least a substantial majority of the most recent authors concerned with the relevant taxon". We checked the number of publications using either spelling after 2000 using the electronic version of the Zoological Record and found that 17 works published after 2000 used schneiderii while 28 used schneideri. We interpret this as a lack of clear support for a prevailing usage of the incorrect subsequent spelling and thus adopt the original spelling E. schneiderii.

Considerable divergence within the genus Anguis has been revealed by means of genetic Downloaded from Brill.com๑4/26/2023 02:26:09PM 
and morphological analyses (Cabela and Grillitsch, 1989; Gvoždík et al., 2010). This led to the recognition of $A$. graeca and A. colchica, resulting in the acceptance of at least four Anguis species in Europe by Gvoždík et al. (2010) and, subsequently, SBC2010. Although no Italian specimens were incorporated in previous analyses, Anguis fragilis was hitherto presumed to inhabit much of western, central and eastern Europe, including the Italian Peninsula (Gvoždík et al., 2010). More recently, Gvoždík et al. (2013) showed Italian Anguis to represent a deeply differentiated mtDNA clade, which presumably diverged during or shortly after the basal radiation within the genus. Genetic distances between the Italian clade and all recognised species are larger than the interspecific distances among $A$. fragilis, A. graeca and $A$. colchica. Hence, Gvoždík et al. (2013) proposed to recognise the populations from Italy and adjacent extreme south-eastern France as Anguis veronensis. Two specimens (one from NE Italy and one from Slovenia) were heterozygous for the most common A. fragilis and A. veronensis PRLR haplotypes and carried A. fragilis mtDNA, indicating hybridisation. While morphological differentiation between $A$. veronensis and A. fragilis is significant, the ranges of all studied characters overlap. In light of the earlier accepted splits among the European Anguis by SBC2010, the divergence during the basal radiation of the genus, and the genetic and morphological evidence presented by Gvoždík et al. (2013), we recognise the Italian and southeastern French populations as A. veronensis.

Albert and Fernández (2009) partitioned the Iberian Worm Lizard Blanus cinereus into two species, attributing southwestern Iberian populations to the cryptic Blanus mariae and designating a lectotype for $B$. cinereus. Their lectotype designation was, however, found to be invalid, due to the lack of explicitly stated taxonomic purpose, while they did not establish whether the original type series consists of one holotype or several syntypes, nor examined the status of other, older nomina in the synonymy of
Iberian Blanus (SBC2010). These issues were tackled by Ceríaco and Bauer (2018), who argued that the type locality of Amphisbaena cinerea Vandelli, 1797 falls within the range of populations attributed to $B$. mariae by Albert and Fernández (2009). To further strengthen their interpretation, they made a valid neotype designation for $B$. cinereus, selecting a neotype belonging to the south-western Iberian species. This effectively places $B$. mariae in the synonymy of $B$. cinereus, which becomes the valid name for the south-western Iberian Blanus species. In agreement with Sampaio et al. (2015), who confirmed that the two Iberian Blanus clades show high levels of mitochondrial differentiation and no signs of nuclear haplotype sharing, Ceríaco and Bauer (2018) accepted the existence of two Iberian Blanus species. However, they deemed no name to be valid for the Central Iberian species. Yet, two older names, Amphisbaena oxyura Wagler, 1824 and Amphisbaena rufa Hemprich, 1820, are available and relate to Blanus from Spain. The type specimen of $A$. oxyura is lost, while its type locality ('Spain', according to Wagler, 1830) makes it impossible to link this name to either of the two Spanish Blanus species. The name A. rufa was based on a holotype that is still present in the Zoological Museum in Berlin (ZMB), but the catalogue entry for this specimen shows that it originates from southern Spain, where both Blanus clades occur. As morphological identification of the two Spanish Blanus species is currently impossible, robust attribution of A. rufa to either clade requires molecular data. Yet, this is problematic with the currently available methods (Ceríaco and Bauer, 2018). Ceríaco and Bauer (2018) thus treated these two names as nomina dubia and created the new nomen Blanus vandellii. SBC2010 had already recognised the two Iberian Blanus clades at species level. We follow this arrangement, and accept that $B$. mariae is a junior synonym of $B$. cinereus, with the latter being the valid name for the southwestern Blanus clade (Ceríaco and Bauer, 2018). 
However, instead of introducing a new name in the form of $B$. vandellii, we promote the use of the oldest available name, Blanus rufus, as the valid name for the central clade until information on the identity of the A. rufa holotype can be obtained. Rather than discarding the old name until proven to apply, we advocate that when an available name exists, it should be used until proven not to apply to the relevant taxon. We thus list the two Iberian species as B. cinereus (south-western species) and B. rufus (north-eastern species).

Hedges et al. (2014) present molecular and morphological data to clarify the phylogeny of the Typhlopidae and split the large genus $T y$ phlops into a number of well-defined new genera. As a consequence, the European blind snake species is now referred to as Xerotyphlops vermicularis. Additionally, according to Hedges et al. (2014), the non-native Flowerpot Snake, recently introduced to Italy and Spain (ZamoraCamacho, 2017; Paolino, Scotti and Grano, 2019), is now called Indotyphlops braminus.

The name of Hierophis viridiflavus has been involved in nomenclatural debate over the last few decades, but are now solved (ICZN Opinions 1463 and 1686). In 1833, Charles-Lucien Bonaparte (the nephew of Napoleon) described Coluber viridi-flavus carbonarius for the eastern Italian populations that are completely or almost completely black. The subspecies $H$. v. carbonarius was considered valid, until Schätti and Vanni (1986) placed it in the synonymy of the nominal form. A series of phylogeographic studies based on mtDNA and nuclear DNA confirmed that viridiflavus and carbonarius are distinct evolutionary lineages which form reciprocally monophyletic clades in mtDNA (Nagy et al., 2001; Rato et al., 2009; Mezzasalma et al., 2015; Avella, Castiglia and Senczuk, 2017). These two lineages differ in the morphology of their $\mathrm{W}$ chromosomes (submetacentric in the $\mathrm{E}$ clade and telocentric in the $\mathrm{W}$ clade - Mezzasalma et al., 2015). As a consequence, they have been treated as valid subspecies since Nagy et al. (2001). In 2015, Mezzasalma et al. (2015) proposed to treat $H$. viridiflavus and $H$. carbonarius as different species on the basis of (i) different morphology of the $\mathrm{W}$ sex chromosome, (ii) reciprocal monophyly in mtDNA with a genetic divergence of $4 \%$ in both cyt $b$ and ND4, and (iii) morphological differentiation consistent with mtDNA differentiation. However, Rato et al. (2009) found a lack of general agreement between colour pattern and mtDNA clade in Italy, and no differences in the nuclear intron beta-fibrinogen intron 7 between the two lineages. The amount of divergence in mtDNA between $H$. v. carbonarius and $H$. v. viridiflavus is much lower than between $H$. gemonensis and $H$. viridiflavus, while the amount of divergence in PRLR between them resembles the divergence within $H$. gemonensis. The sample size for the chromosomes is quite low as well. The split of $H$. v. carbonarius from $H$. v. viridiflavus did not reach broad support in the TC, as several members felt the evidence is still insufficient, and they prefer to wait for information on genetic variation near the contact zones. We thus recommend to maintain $\mathrm{Hi}$ erophis viridiflavus carbonarius as a subspecies for the time being.

Jablonski et al. (2019) applied phylogenetic and morphological analyses to range-wide sampled data, aiming to better understand the intraspecific relationships and biogeography of Elaphe sauromates, and subsequently revised its taxonomy. Known from the Balkans, Anatolia, the Caucasus, the Ponto-Caspian steppes, and the Levant, this species has been suspected to be composed of two or more genetically diverse populations (Lenk, Joger and Wink, 2001). Sequences from 63 specimens and morphological data from 95 specimens were analysed. The authors found two distinct evolutionary lineages, one of which represents a new species, Elaphe urartica. The new species is distributed in eastern Turkey, Georgia, Armenia, Azerbaijan, Nagorno-Karabakh, Iran, and Russia (Dagestan). The mtDNA genetic distances between E. sauromates and E. urartica (6-8\% 
in COI and ND4) were interpreted as indicating a split at the Miocene-Pliocene boundary (5-8 Mya; see Kornilios et al., 2014), thus they presumably separated not very long after their common ancestors separated from E. quatuorlineata. Two out of four analysed nuclear genes were also clearly differentiated, though closely related, between E. urartica and E. sauromates, while the remaining two showed signs of incomplete lineage sorting. Both lineages are also moderately morphologically differentiated and, while none of the characters are exclusively diagnostic, their combination can be used for confident lineage identification. Conclusively, we accept Elaphe urartica as a separate species.

The ladder snake Rhinechis scalaris is characterised by a backward-oriented rostral scale that is wedged between the internasal scales. Apart from this striking feature, external morphology of $R$. scalaris has long been acknowledged to closely match that of Zamenis rat snakes (Salvi et al., 2018). Multiple recent phylogenetic assessments have revealed that Rhinechis (with the sole member $R$. scalaris) and Zamenis are closely related (Burbrink and Lawson, 2007; Pyron et al., 2011; Pyron, Burbrink and Wiens, 2013; Zheng and Wiens, 2016). Some of these studies found Zamenis to be paraphyletic in respect to Rhinechis, while others placed Rhinechis as sister to all Zamenis species, albeit with low support (reviewed by Salvi et al., 2018). The latter authors argue that this phylogenetic uncertainty reflects an evolutionary scenario in which early cladogenetic events took place at the same time or within a short time frame, making it hard to disentangle which (if any) lineage branched off first. Using two mitochondrial and five nuclear genes, Salvi et al. (2018) then inferred phylogenetic relationships between Zamenis and Rhinechis. They recovered a strongly supported clade consisting of Rhinechis scalaris and Zamenis, while the monophyly of Zamenis without scalaris remained poorly supported. As a result, these authors proposed to include scalaris in Zamenis. In agreement with the 'clade stability' taxon naming criterion of Vences et al. (2013a) and as a named genus of uncontroversial monophyly is obtained, we here follow this.

The California Kingsnake Lampropeltis getula californiae has been introduced to Gran Canaria, where it turned into a problematic invasive species (Monzón-Arguëllo et al., 2015; Fisher et al., 2019). Based on mtDNA data and morphological variation, Pyron and Burbrink (2009) elevated L. g. californiae and four other subspecies to species status. While the basal division in their phylogeny has $L$. g. getula and $L$. g. nigra in the one main branch and L. g. holbrooki, L. g. splendida and L. g. californiae in the other, the division between $L . g$. splendida and L. g. californiae is retrieved as the most recent one. Pending the publication of a multilocus analysis or a detailed study of the various contact zones, we maintain $L$. g. californiae as a subspecies of the Common Kingsnake Lampropeltis getula for the time being.

The groundwork of contemporary elucidation of the Natrix natrix complex was initiated by the mitochondrial phylogeography of Kindler et al. (2013), leading to rejection of Natrix megalocephala and the identification of multiple contact zones, three of which were further investigated more recently (see below). Subsequently, a virtual lack of gene flow between $N$. natrix helvetica and $N$. natrix astreptophora and the differentiation between both taxa established on multiple sources of evidence, such as microsatellites, mtDNA, osteology and external morphology, led to suggesting species status for Natrix astreptophora (Pokrant et al., 2016). Within central Europe, Kindler et al. (2017) investigated two macro-scale transects across $\mathrm{Na}$ trix transition zones. The eastern contact zone between two lineages identified by Kindler et al. (2013) as running from Central Europe to the southern Balkans displayed wide-reaching introgression. In contrast, the western contact zone between the traditional subspecies $N$. $n$. natrix and $N$. $n$. helvetica in western Germany was shown to be narrow (microsatellite cline width of about $40 \mathrm{~km}$ ), with a deficit of admixed 
individuals generating a bimodal hybrid zone, indicative of strongly restricted gene flow. We therefore accept $N$. astreptophora and $N$. helvetica as valid species in addition to $N$. natrix.

Ferchaud et al. (2012) provided a wellresolved mitochondrial phylogeny of the Vipera ursinii complex, which indicates that the renardi clade, the ursinii clade and the graeca clade diverged approximately 3-4 Mya. The divergence between these three clades is of the same magnitude as between the two widely accepted species V. berus and V. seoanei. The renardi and ursinii clades do not seem to share haplotypes, although they inhabit similar habitats along the north-western Black Sea coast where Vipera ursinii moldavica occurs. Given the level of genetic divergence, lack of haplotype sharing, marked morphological divergence and lack of well supported morphological intergradation, it seems more adequate to treat $V$. renardi as specifically distinct from $V$. ursinii. Given its well-supported position at the base of a renardi + ursinii clade and although we verified a very low genetic distance between ursinii and graeca in cyt $b(3.2 \%)$, this arrangement makes it necessary to treat $V$. graeca as a distinct species as well. Additional morphological and mtDNA and nuclear DNA data support the distinct position of the graeca clade (Mizsei et al., 2017). Several other taxa from the Caucasus and the Middle East have been put forward as valid species, two of which occur in our area: the Caucasian lotievi and the recently described shemakhensis (Tuniyev et al., 2013) from north-eastern Azerbaijan. A recent phylogenomic (RADseq data) analysis of multiple specimens of renardi and lotievi by $\mathrm{Zi}$ nenko et al. (2016) showed a lack of genetic differentiation at the genome scale between specimens collected in the lowlands (renardi) and Caucasian uplands (lotievi). There is no genetic information for shemakhensis, which is, however, very similar to lotievi morphologically. In conclusion, we consider three European species within the Vipera ursinii complex: V. graeca, V. renardi and $V$. ursinii, and recommend treating
$V . r$ lotievi and V.r. shemakhensis as conspecific with $V$. renardi.

Tuniyev and Ostrovskikh (2001) described Vipera orlovi and V. magnifica, two viper species from the Russian Caucasus that are related to Vipera kaznakovi. Vipera orlovi inhabits both slopes of the northwesternmost Caucasus, while V. magnifica is described from the Malaja Laba river valley and restricted to Krasnodar territory. As no molecular data was provided, and it was later shown that both taxa share mtDNA haplotypes with V. kaznakovi (Zinenko et al., 2015), further enquiry was needed. $\mathrm{Zi}$ nenko et al. (2016) used genomic methods to demonstrate the hybrid origin of these taxa, with parapatric $V$. kaznakovi and $V$. renardi as likely parental species. Low admixture and limited genetic differentiation led these authors to treat $V$. magnifica as a synonym of $V$. kaznakovi. The authors build a case for not revoking the species status of $V$. orlovi by advocating caution with regards to its conservation status. While we do not reject species of hybrid origin per se, the 2016 data does not suggest reproductive isolation or strong genetic differentiation of either taxon in relation to $V$. kaznakovi. Thus, we do not treat V. magnifica or $V$. orlovi as valid species. As they are more closely related to $V$. kaznakovi than to $V$. renardi, we treat both as conspecific with $V$. kaznakovi. In addition, we disagree with Zinenko et al. (2016) that the Code does not allow the recognition of taxa with hybrid ancestry. The Code rules nomenclature, not systematics, and nothing in the Code precludes treating taxa of admixed ancestry as valid. As both orlovi and magnifica were described on the base of distinct phenotypic features, we tentatively maintain them as subspecies of $V$. kaznakovi ( $V . k$. orlovi and $V$. k. magnifica) until a detailed examination of morphological variation might show them not to be morphologically distinct.

A new viper species, named Vipera walser, was described from northern Piedmont, Italy (Ghielmi et al., 2016) based on mtDNA, nuclear DNA and morphological discriminant analyses. Remarkably, while morphologically very Downloaded from Brill.come4/26/2023 02:26:09PM 
similar to north Italian $V$. berus, mtDNA data showed the new taxon to be nested with geographically distant taxa of the ursinii-kaznakovi complex. For two protein-coding nuclear genes (BACH2 and RAG1), V. walser does not share haplotypes with $V$. berus. However, only single individuals of both species have so far been sequenced. Moreover, for RAG1, the new species is similar to $V$. berus, while no sequences of the ursinii complex exist for this gene. Therefore, the existence of cytonuclear discordance cannot be discarded. Until additional nuclear DNA data confirms the distinct nature of the walser population, we consider acceptance of the new species to be premature, and tentatively regard it as a population of $V$. berus with distinct, perhaps introgressed, mtDNA. Morphologically, $V$. walser does not differ much from the $V$. berus populations inhabiting the Italian Alps (the Italian clade of $V$. berus in Ursenbacher et al., 2006) but it is easily distinguishable from the Central and Northern European populations of $V$. berus. Thus, the Italian Alps populations of $V$. berus could be treated as a subspecies under the name $V$. b. walser. However, we refrain from making formal recommendations here, pending a detailed analysis of morphological variation between populations of $V$. berus from the Italian Alps (including the populations described as $V$. walser) and the rest of the $V$. berus populations.

The populations of mostly black adders inhabiting the forest-steppe zone of the south and south-eastern parts of the East European Plain have been described as Vipera nikolskii Vedmederya, Grubant and Rudaeva, 1986. The distribution and morphological characters of nikolskii compared to berus have been reviewed by Bakiev, Böhme and Joger (2005), Milto and Zinenko (2005) and Zinenko, Ţurcanu and Strugariu (2010, who showed that populations of nikolskii from the western parts of its range can be mostly composed of nonmelanistic specimens). According to Milto and Zinenko (2005), several older names created by Pallas for black adders from southern Russia were based on populations resulting from intergradation between berus and nikolskii and cannot apply to the later taxon, leaving nikolskii as the valid nomen for this taxon. While it was first described at species rank, nikolskii is now variously treated as a full species (e.g. Bakiev, Böhme and Joger, 2005; Uetz, Freed and Hošek, 2019) or as a subspecies of Vipera berus (e.g. SBC2010; Zinenko, T3urcanu and Strugariu, 2010; Mizsei et al., 2017; Crnobrnja Isailovic et al., 2019 by implication). Depending on their geographical origin, specimens of nikolskii either carry berus mtDNA haplotypes, or haplotypes grouping (within the diversity of the berus group) close to $V . b$. barani (Joger et al., 1997; Kalyabina-Hauf et al., 2004). A multilocus phylogeny places nikolskii within $\mathrm{V}$. berus (Mizsei et al., 2017). Detailed morphological studies show extensive introgression in the contact zones with V. b. berus (Zinenko, 2004; Milto and Zinenko, 2005; Zinenko, Ţurcanu and Strugariu, 2010). We thus maintain the treatment of SBC2010 and consider nikolskii as conspecific with V. berus, supporting its recognition as $V$. b. nikolskii to acknowledge its morphological and ecological peculiarities.

The correct spelling of the specific epithet of the Lataste's viper has been a matter of long lasting debates because Boscá (1878) used the spelling "Vipera Latasti" in the text and "Vipera latastei" in the caption for the accompanying plate, with both spellings in current use in the literature (see Alonso-Zarazaga, 2013 and Salvador et al., 2014 for summaries). Following an application to the International Commission on Zoological Nomenclature (ICZN) by Salvador et al. (2014), the ICZN (2017) confirmed that Vipera latastei Boscá, 1878 is the correct original spelling of the specific name.

Frétey (2019) provided compelling argumentation of why the capitalised epithet Lebetinus in Coluber Lebetinus Linnaeus, 1758 is a noun in apposition and must be treated as invariable. We agree with his interpretation, and accept that the Blunt-nosed Viper should be called Macrovipera lebetinus. 
Based on morphology, Nilson and Andrén (1988) elevated Macrovipera lebetinus schweizeri to species rank. Stümpel (2012), however, found that the mtDNA haplotypes found in M. schweizeri are not limited to the Milos archipelago, but are also present near Mersin on the Turkish mainland. This author thus pointed out that treating $M$. schweizeri as a valid species might render M. lebetinus paraphyletic. Furthermore, they showed that in their mtDNA trees schweizeri is neither basal to the rest of the M. lebetinus haplotypes, nor highly divergent. Yet, while Stümpel's dissertation is available, and a (brief) sentence in Stümpel and Joger (2009) refers to these results, these findings have not yet been properly published in a peerreviewed journal, and the relevant Macrovipera sequences are not yet available in GenBank either. As a consequence, many TC members felt that a formal taxonomic decision on this case would be premature, and, while it is likely that schweizeri is best treated as a subspecies, the decision can only be taken after the evidence has been properly published, or the data has been made publicly available. Conclusively, we maintain Macrovipera schweizeri at species level for now.

The occurrence of the genus Gloydius inside the area covered by this list is unclear. The only European area where the occurrence of the genus has been reported is north of the Caspian Sea, between the Volga and Ural valleys. As explained by Conant (1982) and Dirksen and Böhme (2005), all records supported by specimens in museum collections are either on the east side of the Ural River, hence outside our area (Induski Hills = Indersky Mountains), or cannot be precisely localised (one specimen from "Gur'jev", now Atyrau, which lies at the mouth of the Ural River on both sides of the river). Attempts to locate Gloydius west of the Ural River have failed (Conant, 1982; Bakiev, Ratnikov and Zinenko, 2007; Sarayev and Pestov, 2010; Simonov, pers. comm.). Thus, no modern records of the presence of the genus in Europe exist, and no record is supported by a collected specimen. The possible occurrence of Gloydius within Europe is based on several ancient sources that report the genus between the Volga and Ural rivers in the dry steppes or deserts east of Astrakhan (see Conant, 1982 and Bour, 1993 for details). They all seem to originate from just two original sources: Gmelin (1789), who mentions the arid deserts of Astrakhan for Coluber halys, and Pallas (1799), who, in his book devoted to his second journey to the southern areas of Russia, mentions (on p. 112) the species "Berus" and "Halys" were seen in an area called "Saltan-Murat" and located east of the Volga River, in an area of dry steppes close to Astrakhan (more precisely north-east of present-day Krasnyy Yar, see Conant, 1982 and Bour, 1993). All subsequent references are based on these two sources. It is even unclear if the mention of the deserts of Astrakhan in J.F. Gmelin's book is based on original information he received from his uncle J.G. Gmelin, who also travelled widely in Russia including the Caspian Sea area, from Pallas himself, or from any other source. J.F. Gmelin never visited these areas himself. We may never know how reliable these old records are. However, the other venomous species mentioned by Pallas (1799) from the same area, Vipera berus, is currently absent from the dry areas between the Ural and Volga Rivers. This casts doubt on the reliability of these observations. In summary, the presence of the genus Gloydius west of the Ural River entirely rests on unsubstantiated records that cannot be verified. We thus believe the species should be formally removed from the list of $\mathrm{Eu}-$ ropean species. In addition, we note that the systematics and nomenclature of the Gloydius halys complex (for a brief review, see Wagner et al., 2016) remain problematical. One of the contentious issues is the type locality of Coluber halys Pallas 1776, which determines the valid name of the Gloydius taxon occurring close to Europe in western Kazakhstan, but this question might need to be settled by an application to the Commission. 


\section{Species list}

Within the area considered for our species list, a number of non-native species have been introduced and/or have become established, and are reproducing. As far as they were not yet listed in the starting point species lists mentioned in the introduction, we add these naturalised species here. More precisely, these are Tenuidactylus bogdanovi (see above), Darevskia dahli (see above), Indotyphlops braminus (see above), Elaphe schrenckii (introduced and persisting in the Netherlands, see Van de Koppel et al., 2012), and Lampropeltis getula (see above).

While no objective standards exist to choose vernacular names, to improve user-friendliness of the list, we added English species names, most of which were adopted from Speybroeck et al. (2016). Others were added to harmonise as much as possible with those of Speybroeck et al. (2016) and Arnold and Ovenden (2002), or with suggestions in the respective species description, or they are newly proposed here.

Changes, as discussed in the text, are marked in bold. Non-native species are marked with an asterisk. Taxa above genus level are listed in traditional order, genera and species arranged alphabetically. For the Class Reptilia, we restrict ourselves to non-avian reptiles and disregard the Subclass Aves.

Class Amphibia Linnaeus, 1758

Order Caudata Scopoli, 1777 or Urodela

Duméril, 1805

Family Hynobiidae Cope, 1859 (1856)

Salamandrella Dybowski, 1870

Salamandrella keyserlingii Dybowski, 1870 - Siberian Salamander

Family Salamandridae Goldfuss, 1820

Calotriton Gray, 1858

Calotriton arnoldi Carranza and Amat, 2005 - Montseny Brook Newt

Calotriton asper (Dugès, 1852) - Pyrenean Brook Newt

Chioglossa Bocage, 1864

Chioglossa lusitanica Bocage, 1864 Golden-striped Salamander
Euproctus Gené, 1839

Euproctus montanus (Savi, 1838) - Corsican Brook Newt

Euproctus platycephalus (Gravenhorst, 1829) - Sardinian Brook Newt

Ichthyosaura Sonnini and Latreille, 1801

Ichthyosaura alpestris (Laurenti, 1768) Alpine Newt

Lissotriton Bell, 1839

Lissotriton boscai (Lataste in Tourneville, 1879) - Bosca's Newt

Lissotriton graecus (Wolterstorff, 1906) - Greek Smooth Newt

Lissotriton helveticus (Razoumowsky, 1789) - Palmate Newt

Lissotriton italicus (Peracca, 1898) - Italian Newt

Lissotriton maltzani (Boettger, 1879) Maltzan's Newt

Lissotriton montandoni (Boulenger, 1880) - Montandon's Newt

Lissotriton vulgaris (Linnaeus, 1758) Smooth Newt

Lyciasalamandra Veith and Steinfartz, 2004

Lyciasalamandra helverseni (Pieper, 1963) - Karpathos Salamander

Lyciasalamandra luschani (Steindachner, 1891) - Luschan's Salamander

Pleurodeles Michahelles, 1830

Pleurodeles waltl Michahelles, 1830 Sharp-ribbed Newt

Salamandra Garsault, 1764

Salamandra atra (Laurenti, 1768) - Alpine Salamander

Salamandra corsica (Savi, 1838) - Corsican Fire Salamander

Salamandra lanzai (Nascetti, Andreone, Capula and Bullini, 1988) - Lanza's Salamander

Salamandra salamandra (Linnaeus, 1758) - Fire Salamander

Salamandrina Fitzinger, 1826

Salamandrina perspicillata (Savi, 1821) Northern Spectacled Salamander 
Salamandrina terdigitata (Bonnaterre, 1789) - Southern Spectacled Salamander

Triturus Rafinesque, 1815

Triturus carnifex (Laurenti, 1768) - Italian Crested Newt

Triturus cristatus (Laurenti, 1768) - Great Crested Newt

Triturus dobrogicus (Kiritzescu, 1903) Danube Crested Newt

Triturus ivanbureschi Arntzen and Wielstra, 2013 - Buresch's Crested Newt

Triturus karelinii (Strauch, 1870) - Karelin's Crested Newt

Triturus macedonicus (Karaman, 1922) Macedonian Crested Newt

Triturus marmoratus (Latreille, 1800) Marbled Newt

Triturus pygmaeus (Wolterstorff, 1905) Southern Marbled Newt

\section{Ommatotriton Gray, 1850}

Ommatotriton ophryticus (Litvinchuk, Zuiderwijk, Borkin and Rosanov, 2005) - Northern Banded Newt

Family Plethodontidae Gray, 1850

Speleomantes Dubois, 1984

Speleomantes ambrosii (Lanza, 1955) -

Ambrosi's Cave Salamander

Speleomantes flavus (Stefani, 1969) Monte Albo Cave Salamander

Speleomantes genei (Temminck and Schlegel, 1838) - Gené's Cave Salamander

Speleomantes imperialis (Stefani, 1969) Imperial Cave Salamander

Speleomantes italicus (Dunn, 1923) - Italian Cave Salamander

Speleomantes sarrabusensis Lanza, Leo, Forti, Cimmaruta, Caputo and Nascetti, 2001 - Sette Fratelli Cave Salamander

Speleomantes strinatii (Aellen, 1958) -

Strinati's Cave Salamander

Speleomantes supramontis (Lanza,

Nascetti and Bullini, 1986) - Supramonte Cave Salamander

Family Proteidae Gray, 1825
Proteus Laurenti, 1768

Proteus anguinus Laurenti, 1768 - Olm

Order Anura Duméril, 1805

Family Alytidae Fitzinger, 1843

Alytes Wagler, 1829

Alytes almogavarii Arntzen and GarcíaParís, 1995 - Catalonian Midwife Toad

Alytes cisternasii Boscá, 1879 - Iberian Midwife Toad

Alytes dickhilleni Arntzen and GarcíaParís, 1995 - Betic Midwife Toad

Alytes muletensis (Sanchiz and Adrover, 1979) - Mallorcan Midwife Toad

Alytes obstetricans (Laurenti, 1768) -

Common Midwife Toad

Discoglossus Otth, 1837

Discoglossus galganoi Capula, Nascetti, Lanza, Bullini and Crespo, 1985 Iberian Painted Frog

Discoglossus montalentii Lanza, Nascetti, Capula and Bullini, 1984 - Corsican Painted Frog

Discoglossus pictus Otth, 1837 - Painted Frog

Discoglossus sardus Tschudi in Otth, 1837 - Tyrrhenian Painted Frog

Family Bombinatoridae Gray, 1825

Bombina Oken, 1816

Bombina bombina (Linnaeus, 1761) -

Fire-bellied Toad

Bombina variegata (Linnaeus, 1758) Yellow-bellied Toad

Family Pipidae Gray, 1825

Xenopus Wagler, 1827

*Xenopus laevis (Daudin, 1802) - African Clawed Toad

Family Pelobatidae Bonaparte, 1850

Pelobates Wagler, 1830

Pelobates balcanicus Karaman, 1928 Balkan Spadefoot Toad

Pelobates cultripes (Cuvier, 1829) - Western Spadefoot Toad

Pelobates fuscus (Laurenti, 1768) - Common Spadefoot Toad 
Pelobates syriacus Boettger, 1889 - Eastern Spadefoot Toad

Pelobates vespertinus (Pallas, 1771) Pallas's Spadefoot Toad

Family Pelodytidae Bonaparte, 1850

Pelodytes Bonaparte, 1838

Pelodytes atlanticus Díaz-Rodríguez, Gehara, Márquez, Vences, Gonçalves, Sequeira, Martínez-Solano and Tejedo, 2017 - Portuguese Parsley Frog

Pelodytes caucasicus Boulenger, 1896 Caucasian Parsley Frog

Pelodytes ibericus Sánchez-Herráiz, Barbadillo, Machordom and Sanchiz, 2000 Iberian Parsley Frog

Pelodytes punctatus (Daudin, 1802) - Parsley Frog

Family Bufonidae Gray, 1825

Bufo Garsault, 1764

Bufo bufo (Linnaeus, 1758) - Common Toad

Bufo spinosus Daudin, 1803 - Spiny Toad

Bufotes Rafinesque, 1815

Bufotes boulengeri (Lataste, 1879) African Green Toad

Bufotes cypriensis Litvinchuk, Mazepa, Jablonski and Dufresnes in Dufresnes et al., 2019 - Cyprus Green Toad

Bufotes viridis (Laurenti, 1768) - Green Toad

\section{Epidalea Cope, 1864}

Epidalea calamita (Laurenti, 1768) Natterjack Toad

Family Hylidae Rafinesque, 1815

Hyla Laurenti, 1768

Hyla arborea (Linnaeus, 1758) - Common Tree Frog

Hyla intermedia Boulenger, 1882 - Italian Tree Frog

*Hyla meridionalis Boettger, 1874 Stripeless Tree Frog

Hyla molleri Bedriaga, 1889 - Iberian Tree Frog
Hyla orientalis Bedriaga, 1890 - Eastern Tree Frog

Hyla sarda (de Betta, 1857) - Tyrrhenian Tree Frog

Hyla savignyi Audouin, 1827 - Savigny's Tree Frog

Family Ranidae Batsch, 1796

Pelophylax Fitzinger, 1843

Pelophylax bedriagae (Camerano, 1882) Levant Water Frog

Pelophylax cretensis (Beerli, Hotz, Tunner, Heppich and Uzzell, 1994) - Cretan Water Frog

Pelophylax epeiroticus (Schneider, Sofianidou and Kyriakopoulou-Sklavounou, 1984) - Epirus Water Frog

Pelophylax kl. esculentus (Linnaeus, 1758) - Edible Frog

Pelophylax kl. grafi (Crochet, Dubois, Ohler and Tunner, 1995) - Graf's Hybrid Frog

Pelophylax lessonae (Camerano, 1882) Pool Frog

Pelophylax perezi (Seoane, 1885) - Iberian Water Frog

Pelophylax ridibundus (Pallas, 1771) Marsh Frog

Pelophylax shqipericus (Hotz, Uzzell, Günther, Tunner and Heppich, 1987) Albanian Pool Frog

Lithobates Fitzinger, 1843

*Lithobates catesbeianus (Shaw, 1802) American Bullfrog

Rana Linnaeus, 1758

Rana arvalis Nilsson, 1842 - Moor Frog

Rana dalmatina Fitzinger in Bonaparte, 1838 - Agile Frog

Rana graeca Boulenger, 1891 - Greek Stream Frog

Rana iberica Boulenger, 1879 - Iberian Stream Frog

Rana italica Dubois, 1987 - Italian Stream Frog

Rana latastei Boulenger, 1879 - Italian Agile Frog 
Rana macrocnemis Boulenger, 1885 Caucasian Frog

Rana parvipalmata Seoane, 1885 - Galician Common Frog

Rana pyrenaica Serra-Cobo, 1993 - Pyrenean Stream Frog

Rana temporaria Linnaeus, 1758 - Common Frog

Class Reptilia Laurenti, 1768

Order Testudines Linnaeus, 1758 or Chelonii

Brongniart, 1800

Family Cheloniidae Oppel, 1811

Caretta Rafinesque-Schmaltz, 1814

Caretta caretta (Linnaeus, 1758) - Loggerhead Turtle

Chelonia Brongniart, 1800

Chelonia mydas (Linnaeus, 1758) - Green Turtle

Eretmochelys Fitzinger, 1843

Eretmochelys imbricata (Linnaeus, 1766) Hawksbill Turtle

Lepidochelys Fitzinger, 1843

Lepidochelys kempii (Garman, 1880) Kemp's Ridley

Lepidochelys olivacea (Eschscholtz, 1829) - Olive Ridley

Family Dermochelyidae Fitzinger, 1843 (1825)

Dermochelys de Blainville, 1816

Dermochelys coriacea (Vandelli, 1761) Leatherback Turtle

Family Testudinidae Batsch, 1788

Testudo Linnaeus, 1758

Testudo graeca Linnaeus, 1758 - Spurthighed Tortoise

Testudo hermanni Gmelin, 1789 - Hermann's Tortoise

Testudo marginata Schoepff, 1792 Marginated Tortoise

Family Geoemydidae Theobald, 1868

Mauremys Gray, 1869

Mauremys caspica (Gmelin, 1774) Caspian Terrapin

Mauremys leprosa (Schweigger, 1812) Spanish Terrapin
Mauremys rivulata (Valenciennes, 1833) Balkan Terrapin

Family Emydidae Rafinesque, 1815

Emys Duméril, 1805

Emys orbicularis (Linnaeus, 1758) - European Pond Terrapin

Trachemys Agassiz, 1857

*Trachemys scripta (Thunberg in Schoepff, 1792) - Pond Slider (Redeared Slider for ssp. elegans)

Family Trionychidae Fitzinger, 1826

Trionyx Geoffroy, 1827

Trionyx triunguis (Forskål, 1775) - Nile Soft-shelled Turtle

Order Squamata Oppel, 1811

Family Agamidae Spix, 1825

Laudakia Gray, 1845

Laudakia caucasia (Eichwald, 1831) Caucasian Agama

Laudakia stellio (Linnaeus, 1758) Starred Agama

Phrynocephalus Kaup, 1825

Phrynocephalus guttatus (Gmelin, 1789) Toad-headed Agama

Phrynocephalus helioscopus (Pallas, 1771) - Sunwatcher Toad-headed Agama

Phrynocephalus mystaceus (Pallas, 1776) - Secretive Toad-headed Agama

Trapelus Cuvier, 1817

Trapelus agilis (Olivier, 1804) - Brilliant Ground Agama

Family Chamaeleonidae Rafinesque, 1815

Chamaeleo Laurenti, 1768

*Chamaeleo africanus Laurenti, 1768 - African Chameleon

Chamaeleo chamaeleon (Linnaeus, 1758) - Mediterranean Chameleon

Family Sphaerodactylidae Underwood, 1954

Euleptes Fitzinger, 1843

Euleptes europaea (Gené, 1839) - European Leaf-toed Gecko

Family Gekkonidae Oppel, 1811

Alsophylax Fitzinger, 1843

Alsophylax pipiens (Pallas, 1827) -

Caspian Even-fingered Gecko 
Hemidactylus Oken, 1817

Hemidactylus turcicus (Linnaeus, 1758) Turkish Gecko

Mediodactylus Szczerbak and Golubev, 1977

Mediodactylus bartoni (Štěpánek, 1934) - Cretan Bent-toed Gecko

Mediodactylus danilewskii (Strauch, 1887) - Bulgarian Bent-toed Gecko

Mediodactylus kotschyi (Steindachner, 1870) - Kotschy's Bent-toed Gecko

Mediodactylus oertzeni (Boettger, 1888) Oertzen's Bent-toed Gecko

Mediodactylus orientalis (Štěpánek, 1937) - Eastern Bent-toed Gecko

Mediodactylus russowii (Strauch, 1887) -

Russow's Bent-toed Gecko

Tenuidactylus Szczerbak and Golubev, 1984

*Tenuidactylus bogdanovi Nazarov and Poyarkov, 2013 - Bogdanov's Benttoed Gecko

Tenuidactylus caspius (Eichwald, 1831) Caspian Bent-toed Gecko

Family Phyllodactylidae Gamble, Bauer, Greenbaum and Jackman, 2008

Tarentola Gray, 1825

Tarentola angustimentalis Steindachner, 1891 - East Canary Gecko

Tarentola boettgeri Steindachner, 1891 Gran Canaria Gecko

Tarentola delalandii Duméril and Bibron, 1836 - Tenerife Gecko

Tarentola gomerensis Joger and Bischoff, 1983 - La Gomera Gecko

Tarentola mauritanica (Linnaeus, 1758) Moorish Gecko

Family Lacertidae Batsch, 1788

Acanthodactylus Wiegmann, 1834

Acanthodactylus erythrurus (Schinz,

1833) - Spiny-footed Lizard

Acanthodactylus schreiberi Boulenger,

1918 - Schreiber's Spiny-footed Lizard

Algyroides Bibron and Bory de Saint-Vincent, 1833

Algyroides fitzingeri (Wiegmann, 1834) -

Pygmy Algyroides
Algyroides marchi Valverde, 1958 - Spanish Algyroides

Algyroides moreoticus Bibron and Bory de Saint-Vincent, 1833 - Greek Algyroides Algyroides nigropunctatus (Duméril and Bibron, 1839) - Dalmatian Algyroides

Anatololacerta Arnold, Arribas and Carranza, 2007

Anatololacerta anatolica (Werner, 1900) - Anatolian Rock Lizard

Anatololacerta budaki (Eiselt and Schmidtler, 1986) - Budak's Rock Lizard

Anatololacerta pelasgiana (Mertens, 1959) - Pelasgian Rock Lizard

Archaeolacerta Mertens, 1921

Archaeolacerta bedriagae (Camerano, 1885) - Tyrrhenian Rock Lizard

Dalmatolacerta Arnold, Arribas and Carranza, 2007

Dalmatolacerta oxycephala Duméril and Bibron, 1839 - Sharp-snouted Rock Lizard

Darevskia Arribas, 1997

Darevskia alpina (Darevsky, 1967) Alpine Rock Lizard

*Darevskia armeniaca (Méhely, 1909) Armenian Rock Lizard

Darevskia brauneri (Méhely, 1909) - Brauner's Rock Lizard

Darevskia caucasica (Méhely, 1909) Caucasus Rock Lizard

Darevskia daghestanica (Darevsky, 1967) - Dagestan Rock Lizard

*Darevskia dahli (Darevsky, 1957) Dahl's Rock Lizard

Darevskia derjugini (Nikolsky, 1898) Derjugin's Rock Lizard

Darevskia lindholmi (Lantz and Cyrén, 1936) - Crimean Rock Lizard

Darevskia praticola (Eversmann, 1834) Meadow Lizard

Darevskia rudis (Bedriaga, 1886) Rough-tailed Rock Lizard

Darevskia saxicola (Eversmann, 1834) North-western Caucasus Rock Lizard 
Dinarolacerta Arnold, Arribas and Carranza, 2007

Dinarolacerta montenegrina Ljubisavljević, Arribas, Džukić and Carranza, 2007 Prokletije Rock Lizard

Dinarolacerta mosorensis Kolombatović, 1886 - Mosor Rock Lizard

Eremias Fitzinger in Wiegmann, 1834

Eremias arguta (Pallas, 1773) - Steppe Runner

Eremias velox (Pallas, 1771) - Rapid Steppe Runner

Gallotia Boulenger, 1916

Gallotia atlantica (Peters and Doria, 1882) - Atlantic Lizard

Gallotia bravoana Hutterer, 1985 - La Gomera Giant Lizard

Gallotia caesaris (Lehrs, 1914) Boettger's Lizard

Gallotia galloti (Oudart in Webb and Berthelor, 1939) - Tenerife Lizard

Gallotia intermedia Hernández, Nogales and Martín, 2000 - Tenerife Speckled Lizard

Gallotia simonyi (Steindachner, 1889) - El

Hierro Giant Lizard

Gallotia stehlini (Schenkel, 1901) - Gran

Canaria Giant Lizard

Hellenolacerta Arnold, Arribas and Carranza, 2007

Hellenolacerta graeca Bedriaga, 1886 Greek Rock Lizard

Iberolacerta Arribas, 1997

Iberolacerta aranica (Arribas, 1993) Aran Rock Lizard

Iberolacerta aurelioi (Arribas, 1994) - Aurelio's Rock Lizard

Iberolacerta bonnali (Lantz, 1927) - Pyrenean Rock Lizard

Iberolacerta cyreni (Müller and Hellmich, 1937) - Cyren's Rock Lizard

Iberolacerta galani Arribas, Carranza and Odierna, 2006 - Galan's Rock Lizard Iberolacerta horvathi (Méhely, 1904) Horvath's Rock Lizard
Iberolacerta martinezricai (Arribas, 1996) - Peña de Francia Rock Lizard

Iberolacerta monticola (Boulenger, 1905) - West Iberian Rock Lizard

Lacerta Linnaeus, 1758

Lacerta agilis Linnaeus, 1758 - Sand Lizard

Lacerta bilineata Daudin, 1802 - Western Green Lizard

Lacerta citrovittata Werner, 1935 - Сyclades Green Lizard

Lacerta diplochondrodes Wettstein, 1952 - Eastern Balkan Green Lizard

Lacerta media (Lantz and Cyrén, 1920) Middle East Green Lizard

Lacerta schreiberi Bedriaga, 1878 Schreiber's Green Lizard

Lacerta strigata (Eichwald, 1831) Caspian Green Lizard

Lacerta trilineata Bedriaga, 1886 - Balkan Green Lizard

Lacerta viridis (Laurenti, 1768) - Eastern Green Lizard

Ophisops Ménétries, 1832

Ophisops elegans Ménétries, 1832 Snake-eyed Lacertid

Parvilacerta Arnold, Arribas and Carranza, 2007

Parvilacerta parva (Boulenger, 1887) Dwarf Lizard

Phoenicolacerta Arnold, Arribas and Carranza, 2007

Phoenicolacerta troodica (Werner, 1936) Troodos Rock Lizard

Podarcis Wagler, 1830

Podarcis bocagei (Seoane, 1884) Bocage's Wall Lizard

Podarcis carbonelli Pérez-Mellado, 1981 Carbonell's Wall Lizard

Podarcis cretensis (Wettstein, 1952) - Cretan Wall Lizard

Podarcis erhardii (Bedriaga, 1876) - Erhard's Wall Lizard

Podarcis filfolensis (Bedriaga, 1876) Maltese Wall Lizard 
Podarcis gaigeae (Werner, 1930) - Skyros Wall Lizard

Podarcis guadarramae (Boscá, 1916) Guadarrama Wall Lizard

Podarcis hispanicus (Steindachner, 1870) - Spanish Wall Lizard

Podarcis ionicus (Lehrs, 1902) - Ionian Wall Lizard

Podarcis levendis Lymberakis, Poulakakis, Kaliontzopoulou, Valakos and Mylonas, 2008 - Pori Wall Lizard

Podarcis lilfordi (Günther, 1874) - Lilford's Wall Lizard

Podarcis liolepis (Boulenger, 1905) - Catalonian Wall Lizard

Podarcis melisellensis (Braun, 1877) Dalmatian Wall Lizard

Podarcis milensis (Bedriaga, 1882) - Milos Wall Lizard

Podarcis muralis (Laurenti, 1768) - Common Wall Lizard

Podarcis peloponnesiacus (Bibron and Bory de Saint-Vincent, 1833) - Peloponnese Wall Lizard

Podarcis pityusensis (Boscá, 1883) - Ibiza Wall Lizard

Podarcis raffonei (Mertens, 1952) - Aeolian Wall Lizard

Podarcis siculus (Rafinesque-Schmaltz, 1810) - Italian Wall Lizard

Podarcis tauricus (Pallas, 1814) - Balkan Wall Lizard

Podarcis tiliguerta (Gmelin, 1789) Tyrrhenian Wall Lizard

Podarcis vaucheri (Boulenger, 1905) Vaucher's Wall Lizard

Podarcis virescens Geniez, Sá-Sousa, Guillaume, Cluchier and Crochet, 2014 - Geniez's Wall Lizard

Podarcis waglerianus Gistel, 1868 - Sicilian Wall Lizard

Psammodromus Fitzinger, 1826

Psammodromus algirus (Linnaeus, 1758) Large Psammodromus

Psammodromus hispanicus Fitzinger, 1826 - Spanish Psammodromus
Psammodromus edwarsianus (Dugès, 1829) - Edwards's Psammodromus

Psammodromus occidentalis Fitze, Gonzalez-Jimena, San-Jose, San Mauro and Zardoya, 2012 - Western Psammodromus

Scelarcis Fitzinger, 1843

Scelarcis perspicillata (Duméril and Bibron, 1839) - Moroccan Rock Lizard Teira Gray, 1838

Teira dugesii (Milne-Edwards, 1829) Madeira Rock Lizard

Timon Tschudi, 1836

Timon lepidus (Daudin, 1802) - Ocellated Lizard

Timon nevadensis (Buchholz, 1963) Sierra Nevada Ocellated Lizard

Zootoca Wagler, 1830

Zootoca carniolica Mayer, Böhme, Tiedemann and Bischoff, 2000 Carniolian Lizard

Zootoca vivipara (Jacquin, 1787) Viviparous Lizard

Family Scincidae Oppel, 1811

Ablepharus Fitzinger in Eversmann, 1823

Ablepharus kitaibelii Bibron and Bory de Saint-Vincent, 1833 - Snake-eyed Skink Ablepharus budaki Göcmen, Kumlutas and Tosunoglu, 1996 - Budak's Snake-eyed Skink

Chalcides Laurenti, 1768

Chalcides bedriagai (Boscá, 1880) Bedriaga's Skink

Chalcides chalcides (Linnaeus, 1758) Italian Three-toed Skink

Chalcides coeruleopunctatus Salvador, 1975 - La Gomera Skink

Chalcides ocellatus (Forskål, 1775) Ocellated Skink

Chalcides sexlineatus Steindachner, 1891 - Gran Canaria Skink

Chalcides simonyi Steindachner, 1891 East Canary Skink

Chalcides striatus (Cuvier, 1829) - Iberian Three-toed Skink 
Chalcides viridanus (Gravenhorst, 1851) -

West Canary Skink

Eumeces Wiegmann, 1834

Eumeces schneiderii (Daudin, 1802) Schneider's Skink

Heremites Gray, 1845

Heremites auratus (Linnaeus, 1758) Levant Skink

Heremites vittatus (Olivier, 1804) - Bridled Skink

Ophiomorus Duméril and Bibron, 1839

Ophiomorus kardesi Kornilios, Kumlutaş, Lymberakis and Ilgaz, 2017 - Anatolian Limbless Skink

Ophiomorus punctatissimus (Bibron and Bory de Saint-Vincent, 1833) - Limbless Skink

Family Anguidae Gray, 1825

Anguis Linnaeus, 1758

Anguis cephallonica Werner, 1894 - Peloponnese Slow Worm

Anguis colchica (Nordmann, 1840) - Eastern Slow Worm

Anguis fragilis Linnaeus, 1758 - Slow Worm

Anguis graeca Bedriaga, 1881 - Greek

Slow Worm

Anguis veronensis Pollini, 1818 - Italian Slow Worm

Pseudopus Merrem, 1820

Pseudopus apodus (Pallas, 1775) - Glass Lizard

Family Blanidae Kearney, 2003

Blanus Wagler, 1830

Blanus cinereus (Vandelli, 1797) - Iberian

Worm Lizard

Blanus rufus (Hemprich, 1820) - Central Iberian Worm Lizard

Blanus strauchi (Bedriaga, 1884) - Anatolian Worm Lizard

Family Typhlopidae Merrem, 1820

Indotyphlops Hedges, Marion, Lipp, Marin and Vidal, 2014

*Indotyphlops braminus (Daudin, 1803) -

Flowerpot Snake
Xerotyphlops Hedges, Marion, Lipp, Marin and Vidal, 2014

Xerotyphlops vermicularis (Merrem, 1820) - Worm Snake

Family Erycidae Bonaparte, 1840

Eryx Daudin, 1803

Eryx jaculus (Linnaeus, 1758) - Sand Boa

Eryx miliaris (Pallas, 1773) - Dwarf Sand Boa

Family Psammophiidae Boie, 1827

Malpolon Fitzinger, 1826

Malpolon insignitus (Geoffroy SaintHilaire, 1827) - Eastern Montpellier Snake

Malpolon monspessulanus (Hermann, 1804) - Western Montpellier Snake

Family Natricidae Bonaparte, 1840

Natrix Laurenti, 1768

Natrix astreptophora (Seoane, 1884) Iberian Grass Snake

Natrix helvetica (Lacépède, 1789) Barred Grass Snake

Natrix maura (Linnaeus, 1758) - Viperine Snake

Natrix natrix (Linnaeus, 1758) - Grass Snake

Natrix tessellata (Laurenti, 1768) - Dice Snake

Family Colubridae Oppel, 1811

Coronella Laurenti, 1768

Coronella austriaca Laurenti, 1768 Smooth Snake

Coronella girondica (Daudin, 1803) Southern Smooth Snake

Dolichophis Gistel, 1868

Dolichophis caspius (Gmelin, 1789) Caspian Whip Snake

Dolichophis jugularis (Linnaeus, 1758) Black Whip Snake

Dolichophis schmidti (Nikolsky, 1909) Schmidt's Whip Snake

Eirenis Jan, 1863

Eirenis collaris (Ménétries, 1832) - Collared Dwarf Snake

Eirenis levantinus Schmidtler, 1993 - Levant Dwarf Snake 
Eirenis modestus (Martin, 1838) - Masked

Dwarf Snake

Elaphe Fitzinger, 1833

Elaphe dione (Pallas, 1773) - Steppe Snake

Elaphe quatuorlineata (Bonnaterre, 1790) - Four-lined Snake

Elaphe sauromates (Pallas, 1814) Blotched Snake

*Elaphe schrenckii Strauch, 1876 - Amur Rat Snake

Elaphe urartica Jablonski, Kukushkin, Avcl, Bunyatova, Ilgaz, Tuniyev and Jandzik in Jablonski et al., 2019

Hemorrhois Boie, 1826

*Hemorrhois algirus (Jan, 1863) - Algerian Whip Snake

Hemorrhois hippocrepis (Linnaeus, 1758) - Horseshoe Whip Snake

Hemorrhois nummifer (Reuss, 1834) Coin-marked Snake

Hemorrhois ravergieri (Ménétries, 1832) Spotted Whip Snake

Hierophis Fitzinger in Bonaparte, 1834

Hierophis gemonensis (Laurenti, 1768) -

Balkan Whip Snake

Hierophis viridiflavus (Lacépède, 1789) -

Western Whip Snake

Hierophis cypriensis (Schätti, 1985) Cyprus Whip Snake

Lampropeltis Fitzinger, 1843

*Lampropeltis getula (Linnaeus, 1766) -

Common Kingsnake

Macroprotodon Guichenot, 1850

Macroprotodon brevis (Günther, 1862) Iberian False Smooth Snake

*Macroprotodon cucullatus (Geoffroy Saint-Hilaire, 1827) - Algerian False Smooth Snake

Platyceps Blyth, 1860

Platyceps collaris (Müller, 1878) - Reddish Whip Snake

Platyceps najadum (Eichwald, 1831) Dahl's Whip Snake

Telescopus Wagler, 1830
Telescopus fallax (Fleischmann, 1831) Cat Snake

Zamenis Wagler, 1830

Zamenis hohenackeri (Strauch, 1873) Transcaucasian Rat Snake

Zamenis lineatus (Camerano, 1891) - Italian Aesculapian Snake

Zamenis longissimus (Laurenti, 1768) Aesculapian Snake

Zamenis scalaris (Schinz, 1822) - Ladder Snake

Zamenis situla (Linnaeus, 1758) - Leopard Snake

Family Viperidae Oppel, 1811

Macrovipera Reuss, 1927

Macrovipera lebetinus (Linnaeus, 1758) Blunt-nosed Viper

Macrovipera schweizeri (Werner, 1935) Milos Viper

Montivipera Nilson, Tuniyev, Andrén, Orlov, Joger and Herrmann, 1999

Montivipera xanthina (Gray, 1849) - Ottoman Viper

Vipera Garsault, 1764

Vipera ammodytes (Linnaeus, 1758) Nose-horned Viper

Vipera aspis (Linnaeus, 1758) - Asp Viper

Vipera berus (Linnaeus, 1758) - Adder

Vipera dinniki (Nikolsky, 1913) - Dinnik’s Viper

Vipera graeca Nilson and Andrén, 1988 Greek Meadow Viper

Vipera kaznakovi (Nikolsky, 1909) - Caucasus Viper

Vipera latastei (Boscá, 1878) - Lataste's Viper

Vipera renardi (Christoph, 1861) - Steppe Viper

Vipera seoanei (Lataste, 1879) - Seoane's Viper

Vipera ursinii (Bonaparte, 1835) Meadow Viper

Acknowledgements. We thank the editor Salvador Carranza, as well as Shai Meiri and an anonymous reviewer for their constructive contributions to improve our manuscript. 
Supplementary material. Supplementary material is available online at:

https://doi.org/10.6084/m9.figshare.12161874

\section{References}

Ahmadzadeh, F., Flecks, M., Carretero, M.A., Böhme, W., Ilgaz, C., Engler, J.O., Harris, D.J., Üzüm, N., Rödder, D. (2013): Rapid lizard radiation lacking niche conservatism: ecological diversification within a complex landscape. J. Biogeogr. 40: 1807-1818.

Albert, E.M., Fernández, A. (2009): Evidence of cryptic speciation in a fossorial reptile: description of a new species of Blanus (Squamata: Amphisbaenia: Blanidae) from the Iberian Peninsula. Zootaxa 2234: 56-68.

Alonso-Zarazaga, A. (2013): Vipera latasti vs. V. latastei: a poisoned affair. Graellsia 69: 129-131.

Amann, T., Rykena, S., Joger, U., Nettmann, H.K., Veith, M. (1997): Zur artlichen Trennung von Lacerta bilineata Daudin, 1802 und L. viridis (Laurenti, 1768). Salamandra 33: 255-268.

Arano, B., Esteban, M., Herrero, P. (1993): Evolutionary divergence of the Iberian brown frogs. Ann. Sci. Nat. Zool. 14: 49-57.

Arnold, E.N., Arribas, O., Carranza, S. (2007): Systematics of the Palaearctic and Oriental lizard tribe Lacertini (Squamata: Lacertidae: Lacertinae) with descriptions of eight new genera. Zootaxa 1430: 1-86.

Arnold, E.N., Ovenden, D.W. (2002): A Field Guide to the Reptiles and Amphibians of Britain and Europe, 2nd Edition. Harper Collins Publishers, London.

Arntzen, J.W., de Vries, W., Canestrelli, D., MartínezSolano, I. (2017): Hybrid zone formation and contrasting outcomes of secondary contact over transects in common toads. Mol. Ecol. 26: 5663-5675.

Arntzen, J.W., García-París, M. (1995): Morphological and allozyme studies of midwife toads (genus Alytes), including the description of two new taxa from Spain. Contrib. Zool. 65: 5-34.

Arntzen, J.W., Recuero, E., Canestrelli, D., MartínezSolano, I. (2013): How complex is the Bufo bufo species group? Mol. Phylogenet. Evol. 69: 1203-1208.

Arntzen, J.W., Trujillo, T., Butôt, R., Vrieling, K., Schaap, O., Gutiérrez-Rodríguez, J., Martínez-Solano, I. (2016): Concordant morphological and molecular clines in a contact zone of the Common and Spined toad (Bufo bufo and B. spinosus) in the northwest of France. Front. Zool. 13: 52 .

Arribas, O.J. (2016): Why Caucasilacerta Harris, Arnold et Thomas, 1998 is a nomen nudum? Russ. J. Herpetol. 23 (4): 305-306.

Arribas, O.J. (2017): Oteroiloteroorum and raffonei/raffoneae: The difference between grammatical correctness and validity in Zoological Nomenclature. Butlletí de la Societat Catalana d'Herpetologia 24: 29-32.
Arribas, O.J., Ananjeva, N.B., Carranza, S., Doronin, I.V., Harris, D.J., Orlov, N.L., Orlova, V.F. (2017): The pernicious effect of retroactive changes in the Code: Darevskia and nomenclatorial stability, a reply to $\mathrm{Bu}-$ sack et al. (2016). Basic and Applied Herpetology 31: 125-129.

Arribas, O.J., Ananjeva, N.B., Carranza, S., Doronin, I.V., Orlov, N.L., Orlova, V.F. (2018): Case 3711 - Iberolacerta Arribas and Darevskia Arribas (Chordata, Squamata, Lacertidae): proposals to deem these names available either from Arribas (1997) or from Arribas (1999). The Bulletin of Zoological Nomenclature 75 (1): 122130.

Avella, I., Castiglia, R., Senczuk, G. (2017): Who are you? The genetic identity of some insular populations of Hierophis viridiflavus s.1. from the Tyrrhenian Sea. Acta Herpetologica 12: 209-214.

Baig, K.J., Wagner, P., Ananjeva, N.B., Böhme, W. (2012): A morphology-based taxonomic revision of Laudakia Gray, 1845 (Squamata: Agamidae). Vertebrate Zoology 62 (2): 213-260.

Bakiev, A., Böhme, W., Joger, U. (2005): Vipera (Pelias) [berus] nikolskii Vedmederja, Grubant et Rudaeva, 1986 - Waldsteppenotter. In: Handbuch der Reptilien und Amphibien Europas, Bd. 3/2B. Schlangen (Serpentes) 2, Viperidae, p. 293-309. Joger, U., Stümpel, N., Eds, Aula-Verlag.

Bakiev, A.G., Ratnikov, V.Y., Zinenko, A.I. (2007): About forming of vipers' fauna of the Volga river basin. Proceedings of the Samara science centre of the Russian Academy of Sciences 9: 163-170. (In Russian).

Bauer, A.M., Masroor, R., Titus-McQuillan, J., Heinicke, M.P., Daza, J.D., Jackman, T.R. (2013): A preliminary phylogeny of the Palearctic naked-toed geckos (Reptilia: Squamata: Gekkonidae) with taxonomic implications. Zootaxa 3599: 301-324.

Bellati, A., Carranza, S., Garcia-Porta, J., Fasola, M., Sindaco, R. (2015): Cryptic diversity within the Anatololacerta species complex (Squamata: Lacertidae) in the Anatolian Peninsula: evidence from a multi-locus approach. Mol. Phylogenet. Evol. 82: 219-233.

Beukema, W., de Pous, P., Donaire-Barroso, D., Bogaerts, S., Garcia-Porta, J., Escoriza, D., Arribas, O.J., El Mouden, E.H., Carranza, S. (2013): Review of the systematics, distribution, biogeography and natural history of Moroccan amphibians. Zootaxa 3661: 1-60.

Beukema, W., Nicieza, A.G., Lourenço, A., Velo-Antón, G. (2016): Colour polymorphism in Salamandra salamandra (Amphibia: Urodela), revealed by a lack of genetic and environmental differentiation between distinct phenotypes. J. Zool. Syst. Evol. Res. 54: 127-136.

Beutler, A. (1981): Cyrtodactylus kotschyi (Steindachner 1870) - Ägaischer Bogenfingergecko. In: Handbook Der Reptilien Und Amphibien Europas, p. 53-74. Böhme, W., Ed., Akademische Verlagsgesellschaft, Wiesbaden.

Bingham, R.E., Papenfuss, T.J., Wake, D.B. (2018): Phylogeography and species boundaries in the Hydromantes shastae complex, with description of two new species (Amphibia; Caudata; Plethodontidae). Bull. Mus. Comp. Zool. 161: 403-427. 
Bonaparte, C.L. (1832-1841): Iconografia Della Fauna Italica per le Quattro Classi Degli Animali Vertebrati. Tipografia Salviucci, Roma.

Borkin, L.J., Litvinchuk, S.N., Rosanov, J.M., Milto, K.D. (2001): Cryptic speciation in Pelobates fuscus (Anura, Pelobatidae): evidence from DNA flow cytometry. Amphibia-Reptilia 22: 387-396.

Bour, R. (1993): Les voyages de Peter Simon Pallas et l'origine de Coluber halys (Serpentes Viperidae). Bull. mens. Soc. linn. Lyon 62: 328-340.

Brehm, A., Harris, D.J., Alves, C., Jesus, J., Thomarat, F., Vicente, L. (2003): Structure and evolution of the mitochondrial DNA complete control region in the lizard Lacerta dugesii (Lacertidae, Sauria). J. Mol. Evol. 56: 46-53.

Brown, P., Pestano, J. (1998): Phylogeography of skinks (Chalcides) in the Canary Islands inferred from mitochondrial DNA sequences. Mol. Ecol. 7: 1183-1191.

Brown, P.R., Thorpe, R.S. (1991a): Within-island microgeographic variation in body dimensions and scalation of the skink Chalcides sexlineatus, with testing of causal hypotheses. Biol. J. Linn. Soc. 44: 47-54.

Brown, P.R., Thorpe, R.S. (1991b): Within-island microgeographic variation in the colour pattern of the skink, Chalcides sexlineatus: pattern and cause. J. Evol. Biol. 4: 557-574.

Brückner, M., Klein, B., Düring, A., Mentel, T., Rabus, S., Soller, J.T. (2001): Phylogeographische Analyse des Lacerta viridis/bilineata Komplexes: molekulare Muster und Verbreitung. Mertensiella 13: 45-51.

Burbrink, F.T., Lawson, R. (2007): How and when did Old World ratsnakes disperse into the New World? Mol. Phylogenet. Evol. 43: 173-189.

Busack, S.D., Salvador, A., Bauer, A.M., Kaiser, H. (2016): Darevskia and Iberolacerta (Reptilia, Lacertidae): Arribas, 1997 or 1999 ? The correct dating of two nomenclatural acts affecting Palearctic lizards, and validation of the name Caucasilacerta Harris, Arnold and Thomas, 1998. Bionomina 10: 61-73.

Cabela, A., Grillitsch, H. (1989): Zum systematischen Status der Blindschleiche (Anguis fragilis Linnaeus, 1758) von Nordgriechenland und Albanien (Squamata: Anguidae). Herpetozoa 2: 51-69.

Canestrelli, D., Verardi, A., Nascetti, G. (2007): Genetic differentiation and history of populations of the Italian treefrog Hyla intermedia: lack of concordance between mitochondrial and nuclear markers. Genetica 130: 241255.

Carranza, S., Arnold, E.N., Mateo, J.A., López-Jurado, L.F. (2000): Long-distance colonization and radiation in gekkonid lizards, Tarentola (Reptilia: Gekkonidae), revealed by mitochondrial DNA sequences. Proc. R. Soc. B 267: 637-649.

Carranza, S., Arnold, E.N., Mateo, J.A., Geniez, P. (2002): Relationships and evolution of the north African geckos, Geckonia and Tarentola (Reptilia: Gekkonidae), based on mitochondrial and nuclear DNA sequences. Mol. Phylogenet. Evol. 23: 244-256.
Carranza, S., Arnold, E.N. (2003): Investigating the origin of transoceanic distributions: mtDNA shows Mabuya lizards (Reptilia, Scincidae) crossed the Atlantic twice. Syst. Biodivers. 1: 275-282.

Carranza, S., Arnold, E.N., Geniez, P., Roca, J., Mateo, J.A. (2008): Radiation, multiple dispersal and parallelism in the skinks, Chalcides and Sphenops (Squamata: Scincidae), with comments on Scincus and Scincopus and the age of the Sahara desert. Mol. Phylogenet. Evol. 46: 1071-1094.

Ceríaco, L.M., Bauer, A.M. (2018): An integrative approach to the nomenclature and taxonomic status of the genus Blanus Wagler, 1830 (Squamata: Blanidae) from the Iberian Peninsula. J. Nat. Hist. 52: 849-880.

Červenka, J., Frynta, D., Kratochvíl, L. (2008): Phylogeny and taxonomy of the Middle Eastern geckos of the genus Cyrtopodion and their selected relatives. Zootaxa 1931: 25-36.

Chiari, Y., Cahais, V., Galtier, N., Delsuc, V. (2012a): Phylogenomic analyses support the position of turtles as the sister group of birds and crocodiles (Archosauria). BMC Biology 10: 65.

Chiari, Y., van der Meijden, A., Mucedda, M., Lourenço, J.M., Hochkirch, A., Veith, M. (2012b): Phylogeography of Sardinian cave salamanders (genus Hydromantes) is mainly determined by geomorphology. PLoS ONE 7: e32332.

Colliard, C., Sicilia, A., Turrisi, G.F., Arculeo, M., Perrin, N., Stöck, M. (2010): Strong reproductive barriers in a narrow hybrid zone of West-Mediterranean green toads (Bufo viridis subgroup) with Plio-Pleistocene divergence. BMC Evol. Biol. 10: 232.

Conant, R. (1982): Agkistrodon in Europe. Salamandra 18: 191-195.

Cornetti, L., Belluardo, F., Ghielmi, S., Giovine, G., Ficetola, G.F., Bertorelle, G., Vernesi, C., Hauffe, H.C. (2015a): Reproductive isolation between oviparous and viviparous lineages of the Eurasian common lizard Zootoca vivipara in a contact zone. Biol. J. Linn. Soc. 114: 566-573.

Cornetti, L., Ficetola, G.F., Hoban, S., Vernesi, C. (2015b): Genetic and ecological data reveal species boundaries between viviparous and oviparous lizard lineages. Heredity 115: 517-526.

Crnobrnja Isailovic, J., Vogrin, M., Corti, C., Sá-Sousa, P., Cheylan, M., Pleguezuelos, J.M., Tomović, L., Sterijovski, B., Joger, U., Westerström, A., Borczyk, B., Schmidt, B., Meyer, A., Sindaco, R., Jelić, D. (2019): Vipera berus. The IUCN Red List of Threatened Species 2009: e.T157248A5059709. Downloaded on 26 December 2019.

Crochet, P.-A. (2015): Nomenclatural issues in the Psammodromus hispanicus (Squamata: Lacertidae) species group. Zootaxa 3964: 149-150.

Crottini, A., Andreone, F., Kosuch, J., Borkin, L.J., Litvinchuk, S.N., Eggert, C., Veith, M. (2007): Fossorial but widespread: the phylogeography of the common spadefoot toad (Pelobates fuscus), and the role of the Po Valley as a major source of genetic variability. Mol. Ecol. 16: 2734-2754. 
de Queiroz, K. (2007): Species concepts and species delimitation. Syst. Biol. 56: 879-886.

de Spix, J.B. (1825): Animalia nova sive species novae lacertarum, quas in itinere per Brasiliam annis MDCCCXYII - MDCCCXX jussu et auspiciis Maximiliani Josephi I. Bavariae regis suscepto collegit et descripsit dr. J. B. de Spix, Ordinis Regii Coronae Bavaricae civilis Eques, Academiae scientiarnm Bavaricae Socius ordinarius, Musei Regii zoologici, zootomici et ethnographici Conservator, Academiae Naturae Curiosorum, Societatis literariae Edinburgensis, Moscoviensis etc. Sodalis. F. S. Hübschmanni, Monachil.

Díaz-Rodríguez, J., Goncalves, H., Sequeira, F., SousaNeves, T., Tejedo, M., Ferrand, N., Martínez-Solano, I. (2015): Molecular evidence for cryptic candidate species in Iberian Pelodytes (Anura, Pelodytidae). Mol. Phylogenet. Evol. 83: 224-241.

Dirksen, L., Böhme, W. (2005): Gloydius halys - Halysotter. In: Handbuch der Reptilien und Amphibien Europas, Bd. 3/2B. Schlangen (Serpentes) 2, Viperidae, p. 7-22. Joger, U., Stümpel, N., Eds, Aula-Verlag, Wiesbaden.

Doronin, I.V., Tuniyev, B.S., Kukushkin, O.V. (2013): Differentiation and taxonomy of the Rock Lizards Darevskia (saxicola) complex (Sauria: Lacertidae) according to morphological and molecular analyses. Proceedings of the Zoological Institute of the Russian Academy of Sciences 317: 54-84. (In Russian, English summary).

Dubois, A. (2007): Genitives of species and subspecies nomina derived from personal names should not be emended. Zootaxa 1550: 49-68.

Dubois, A. (2010): Retroactive changes should be introduced in the Code only with great care: problems related to the spellings of nomina. Zootaxa 2426: 1-42.

Dubois, A., Bour, R. (2010): The nomenclatural status of the nomina of amphibians and reptiles created by Garsault (1764), with a parsimonious solution to an old nomenclatural problem regarding the genus Bufo (Amphibia, Anura) and comments on some nomina created by Laurenti (1768). Zootaxa 2447: 1-52.

Dubois, A., Bour, R. (2011): The authorship and date of the familial nomen Ranidae (Amphibia, Anura). Alytes 27: 154-160.

Dubois, A., Raffaëlli, J. (2009): A new ergotaxonomy of the family Salamandridae Goldfuss, 1820 (Amphibia, Urodela). Alytes 26: 1-85.

Dufresnes, C., Martínez-Solano, I. (2020): Hybrid zone genomics supports candidate species in Iberian Alytes obstetricans. Amphibia-Reptilia 41: 105-112.

Dufresnes, C., Brelsford, A., Crnobrnja-Isailović, J., Tzankov, N., Lymberakis, P., Perrin, N. (2015): Timeframe of speciation inferred from secondary contact zones in the European tree frog radiation (Hyla arborea group). BMC Evol. Biol. 15: 155.

Dufresnes, C., Lymberakis, P., Kornilios, P., Savary, R., Perrin, N., Stöck, M. (2018a): Phylogeography of Aegean green toads (Bufo viridis subgroup): continental hybrid swarm vs. insular diversification with discovery of a new island endemic. BMC Evol. Biol. 18: 67.
Dufresnes, C., Majtyka, T., Baird, S.J., Gerchen, J.F., Borzée, A., Savary, R., Ogielska, M., Perrin, N., Stöck, M. (2016): Empirical evidence for large X-effects in animals with undifferentiated sex chromosomes. Sci. Rep. 6: 21029.

Dufresnes, C., Mazepa, G., Jablonski, D., Caliari Oliveira, R., Wenseleers, T., Shabanov, D.A., Auer, M., Ernst, R., Ramírez-Chaves, H.E., Mulder, K.P., Simonov, E., Tiutenko, A., Kryvokhyzha, D., Wennekes, P.L., Zinenko, O.I., Korshunov, O.V., Al-Johany, A.M., Peregontsev, E.A., Betto-Colliard, C., Denoël, M., Borkin, L.J., Skorinov, D.V., Pasynkova, R.A., Mazanaeva, L.F., Rosanov, J.M., Dubey, S., Litvinchuk, S.N. (2019c): Fifteen shades of green: the evolution of Bufotes toads revisited. Mol. Phylogenet. Evol. 141: 106615.

Dufresnes, C., Mazepa, G., Rodrigues, N., Brelsford, A., Litvinchuk, S.N., Sermier, R., Lavanchy, G., BettoColliard, C., Blaser, O., Borzée, A., Cavoto, E., Fabre, G., Ghali, K., Grossen, C., Horn, A., Leuenberger, J., Phillips, B.C., Saunders, P.A., Savary, R., Maddalena, T., Stöck, M., Dubey, S., Canestrelli, D., Jeffries, D.L. (2018b): Genomic evidence for cryptic speciation in tree frogs from the Apennine Peninsula, with description of Hyla perrini sp. nov. Front. Ecol. Evol. 6: 144.

Dufresnes, C., Mazepa, G., Rodrigues, N., Brelsford, A., Litvinchuk, S.N., Sermier, R., Lavanchy, G., BettoColliard, C., Blaser, O., Borzée, A., Cavoto, E., Fabre, G., Ghali, K., Grossen, C., Horn, A., Leuenberger, J., Phillips, B.C., Saunders, P.A., Savary, R., Maddalena, T., Stöck, M., Dubey, S., Canestrelli, D., Jeffries, D.L. (2018c): Formal description of the new tree frog species inhabiting northern Italy and southern Switzerland. Bulletin de la Société Vaudoise des Sciences Naturelles 97: 5-11.

Dufresnes, C., Nicieza, A.G., Litvinchuk, S.N., Rodrigues, N., Jeffries, D.L., Vences, M., Perrin, N., MartínezSolano, I. (2020a): Are glacial refugia hotspots of speciation and cyto-nuclear discordances? Answers from the genomic phylogeography of Spanish common frogs. Mol. Ecol. 29: 986-1000.

Dufresnes, C., Pribille, M., Alard, B., Gonçalves, H., Amat, F., Crochet, P.A., Dubey, S., Perrin, N., Fumagalli, L., Vences, M., Martínez-Solano, I. (2020b): Integrating hybrid zone analyses in species delimitation: lessons from two anuran radiations of the Western Mediterranean. Heredity 124: 423-438.

Dufresnes, C., Strachinis, I., Suriadna, N., Mykytynets, G., Cogalniceanu, D., Skézely, P., Vukov, T., Arntzen, J.W., Wielstra, B., Lymberakis, P., Geffen, E., Gafny, S., Kumlutas, Y., Ilgaz, C., Candan, K., Mizsei, E., Szabolcs, M., Kolenda, K., Smirnov, N., Géniez, P., Lukanov, S., Crochet, P.A., Dubey, S., Perrin, N., Litvinchuk, S.N., Denoël, M. (2019a): Phylogeography of a cryptic speciation continuum in Eurasian spadefoot toads (Pelobates). Mol Ecol. 28: 3257-3270.

Dufresnes, C., Strachinis, I., Tzoras, E., Litvinchuk, S.N., Denoël, M. (2019b): Call a spade a spade: taxonomy and distribution of Pelobates, with description of a new Balkan endemic. ZooKeys 859: 131-158. 
Duz', S.L., Kukushkin, O.V., Nazarov, R.A. (2012): A record of the Turkestan Naked-toed Gecko, Tenuidactylus fedtschenkoi (Sauria: Gekkonidae), in the southwestern Ukraine. Current Studies in Herpetology 12: 123-133.

Edwards, D.L., Melville, J. (2011): Extensive phylogeographic and morphological diversity in Diporiphora nobbi (Agamidae) leads to a taxonomic review and a new species description. J. Herpetol. 45: 530-547.

Eiselt, J., Schmidtler, J.F. (1986): Der Lacerta danfordicomplex (Reptilia: Lacertidae). Spixiana 9: 289-328.

Ferchaud, A.-L., Ursenbacher, S., Cheylan, M., Luiselli, L., Jelic, D., Halpern, B., Major, A., Kotenko, T., Keyan, N., Behrooz, R., Crnobrnja-Isailovic, J., Tomovic, L., Ghira, I., Ioannidis, Y., Arnal, V., Montgelard, C. (2012): Phylogeography of the Vipera ursinii complex (Viperidae): mitochondrial markers reveal an east-west disjunction in the Palaearctic region. J. Biogeogr. 39: 1836-1847.

Fisher, S.R., Fisher, R.N., Alcaraz, S.E., Gallo-Barneto, R., Patino-Martinez, C., López Jurado, L.F., Rochester, C.J. (2019): Life-history comparisons between the native range and an invasive population of a colubrid snake. In: Island Invasives: Scaling up to Meet the Challenge, p. 326-331. Veitch, C.R., Clout, M.N., Martin, A.R., Russell, J.C., West, C.J., Eds, Occasional Paper SSC no. 62. IUCN, Gland, Switzerland.

Fitze, P.S., Gonzalez-Jimena, V., San-Jose, L.M., San Mauro, D., Aragon, P., Suarez, T., Zardoya, R. (2011): Integrative analyses of speciation and divergence in Psammodromus hispanicus (Squamata: Lacertidae). BMC Evol. Biol. 11: 347.

Fitze, P.S., Gonzalez-Jimena, V., San-Jose, L.M., San Mauro, D., Zardoya, R. (2012): A new species of sand racer, Psammodromus (Squamata: Lacertidae), from the western Iberian Peninsula. Zootaxa 3205: 41-52.

Freitas, S., Vavakou, A., Arakelyan, M., Drovetski, S.V., Crnobrnja-Isailović, J., Kidov, A.A., Cogălniceanu, D., Corti, C., Lymberakis, P., Harris, D.J., Carretero, M.A. (2016): Cryptic diversity and unexpected evolutionary patterns in the meadow lizard, Darevskia praticola (Eversmann, 1834). Syst. Biodivers. 14: 184-197.

Frétey, T. (2019): Capitalised epithets in the works of Linnaeus (1758-1767): findings and consequences in herpetology. Bionomina 16: 22-45.

Fritz, U., Fattizzo, T., Guicking, D., Tripepi, S., Pennisi, M.G., Lenk, P., Joger, U., Wink, M. (2005): A new cryptic species of pond turtle from southern Italy, the hottest spot in the range of the genus Emys. Zool. Scr. 34: 351-371.

Fritz, U., Guicking, D., Kami, H., Arakelyan, M., Auer, M., Ayaz, D., Ayres Fernández, C., Bakiev, A.G., Celani, A., Džukić, G., Fahd, S., Havaš, P., Joger, U., Khabibullin, V.F., Mazanaeva, L.F., Široký, P., Tripepi, S., Valdeón Vélez, A., Velo Antón, G., Wink, M. (2007): Mitochondrial phylogeography of European pond turtles (Emys orbicularis, Emys trinacris) - an update. AmphibiaReptilia 28: 418-426.

Frost, D.R., Grant, T., Faivovich, J., Bain, R.H., Haas, A., Haddad, C.F.B., De Sá, R.O., Channing, A., Wilkinson, M., Donnellan, S.C., Raxworthy, C.J., Campbell, J.A.,
Blotto, B.L., Moler, P., Drewes, R.C., Nussbaum, R.A., Lynch, J.D., Green, D.M., Wheeler, W.C. (2006): The amphibian tree of life. Bull. Am. Mus. Nat. Hist. 297: 1-370.

Frost, D.R. (2019): Amphibian Species of the World: an Online Reference. Version 6.0. Available from: http://research.amnh.org/herpetology/amphibia/index. html (Accessed December 2019).

García-París, M. (1995): Variabilidad genética y distribución geográfica de Alytes obstetricans almogavarii en España. Rev. Esp. Herp. 9: 133-138.

Garcia-Porta, J., Irisarri, I., Kirchner, M., Rodríguez, A., Kirchhof, S., Brown, J.L., MacLeod, A., Turner, A.P., Ahmadzadeh, F., Albaladejo, G., Crnobrnja-Isailovic, J., De la Riva, I., Fawzi, A., Galán, P., Göçmen, B., Harris, D.J., Jiménez-Robles, O., Joger, U., Jovanović Glavaš, O., Karış, M., Koziel, G., Künzel, S., Lyra, M., Miles, D., Nogales, M., Anıl Oğuz, M., Pafilis, P., Rancilhac, L., Rodríguez, N., Rodríguez Concepción, B., Sanchez, E., Salvi, D., Slimani, T., S'khifa, A., Turk Qashqaei, A., Žagar, A., Lemmon, A., Moriarty Lemmon, E., Carretero, M.A., Carranza, S., Philippe, H., Sinervo, B., Müller, J., Vences, M., Wollenberg Valero, K.C. (2019): Environmental temperatures shape thermal physiology as well as diversification and genome-wide substitution rates in lizards. Nat. Commun. 10: 4077.

Garcia-Porta, J., Litvinchuk, S.N., Crochet, P.A., Romano, A., Geniez, P.H., Lo-Valvo, M., Lymberakis, P., Carranza, S. (2012): Molecular phylogenetics and historical biogeography of the west-palearctic common toads (Bufo bufo species complex). Mol. Phylogenet. Evol. 63: 113-130.

Gasc, J.-P., Cabela, A., Crnobrnja-Isailović, J., Dolmen, D., Grossenbacher, K., Haffner, P., Lescure, J., Martens, H., Martínez-Rica, J.P., Maurin, H., Oliveira, M.E., Sofianidou, T.S., Veith, M., Zuiderwijk, A. (1997, reprint 2004): Atlas of Amphibians and Reptiles in Europe. Societas Europaea Herpetologica and Muséum national d'Histoire naturelle, Paris.

Gay, L., Crochet, P.-A., Bell, D., Lenormand, T. (2008): Comparing clines on molecular and phenotypic traits in hybrid zones: a window on tension zone models. Evolution 62: 2789-2806.

Geniez, P., Sá-Sousa, P., Guillaume, C., Cluchier, A., Crochet, P.-A. (2014): Systematics of the Podarcis hispanicus complex (Sauria, Lacertidae) III: valid nomina of the western and central Iberian forms. Zootaxa 3794: 1-51.

Gerchen, J.F., Dufresnes, C., Stöck, M. (2018): Introgression across hybrid zones is not mediated by large $\mathrm{X}$ effects in green toads with undifferentiated sex chromosomes. Am. Nat. 192: 178-188.

Ghielmi, S., Menegon, M., Marsden, S.J., Laddaga, L., Ursenbacher, S. (2016): A new vertebrate for Europe: the discovery of a range-restricted relict viper in the western Italian Alps. J. Zool. Syst. Evol. Res. 54: 161173.

Glaw, F. (2015): Taxonomic checklist of chameleons (Squamata: Chamaeleonidae). Vertebr. Zool. 65: 167-246. 
Gmelin, J.F. (1789): Caroli a Linné, Systema Naturae per Regna Tria Naturae, Secundum Classes, Ordines, Genera, Species; cum Characteribus, Differentiis, Synonymis, Locis. Editio Decima Tertia, Aucta, Reformata. vol. I, Part. 3. G. E. Beer, Leipzig.

Godinho, R., Crespo, E.G., Ferrand, N., Harris, D.J. (2005): Phylogeny and evolution of the green lizards, Lacerta spp. (Squamata: Lacertidae) based on mitochondrial and nuclear DNA sequences. Amphibia-Reptilia 26: 271285.

Gonçalves, H., Martínez-Solano, I., Ferrand, N., GarcíaParís, M. (2007): Conflicting phylogenetic signal of nuclear vs mitochondrial DNA markers in midwife toads (Anura, Discoglossidae, Alytes): deep coalescence or ancestral hybridization? Mol. Phylogenet. Evol. 44: 494500.

Gonçalves, H., Maia-Carvalho, B., Sousa-Neves, T., GarcíaParís, M., Sequeira, F., Ferrand, N., Martínez-Solano, I. (2015): Multilocus phylogeography of the common midwife toad, Alytes obstetricans (Anura, Alytidae): contrasting patterns of lineage diversification and genetic structure in the Iberian refugium. Mol. Phylogenet. Evol. 93: $363-379$.

Gübitz, T., Thorpe, R.S., Malhotra, A. (2005): The dynamics of genetic and morphological variation on volcanic islands. Proc. R. Soc. B 272: 751-757.

Gvoždík, V., Jandzik, D., Lymberakis, P., Jablonski, D., Moravec, J. (2010): Slow worm, Anguis fragilis (Reptilia: Anguidae) as a species complex: genetic structure reveals deep divergences. Mol. Phylogenet. Evol. 55: 460-472.

Gvoždík, V., Benkovsky, N., Crottini, A., Bellati, A., Moravec, J., Romano, A., Sacchi, R., Jandzik, D. (2013): An ancient lineage of slow worms, genus Anguis (Squamata: Anguidae), survived in the Italian Peninsula. Mol. Phylogenet. Evol. 69: 1077-1092.

Harper, F. (1940): Some works of Bartram, Daudin, Latreille, and Sonnini, and their bearing upon North American herpetological nomenclature. The American Midland Naturalist 23: 692-723.

Hasegawa, M. (2017): Phylogeny mandalas for illustrating the Tree of Life. Mol. Phyl. Evol. 117: 168-178.

Hedges, S.B. (2014): The high-level classification of skinks (Reptilia, Squamata, Scincomorpha). Zootaxa 3765: 317-338.

Hedges, S.B., Marion, A.B., Lipp, K.M., Marin, J., Vidal, N. (2014): A taxonomic framework for typhlopid snakes from the Caribbean and other regions (Reptilia, Squamata). Caribbean Herpetology 49: 1-61.

Hedges, S.B., Conn, C.E. (2012): A new skink fauna from Caribbean Islands (Squamata, Mabuyidae, Mabuyinae). Zootaxa 3288: 1-244.

Hotz, H., Beerli, P., Uzzell, T., Guex, G.-D., Pruvost, N.M.B., Schreiber, R., Plötner, J. (2013): Balancing a cline by influx of migrants: a genetic transition in water frogs of eastern Greece. J. Hered. 104: 57-71.

International Commission on Zoological Nomenclature (1987): Opinion 1463. De Lacépède, 1788-1789, Histoire Naturelle des Serpents and later editions: rejected as non-binominal work. Bull. Zool. Nom. 44: 265-267.
International Commission on Zoological Nomenclature (1992): Opinion 1686. Natrix gemonensis Laurenti, 1768 (currently Coluber gemonensis), Coluber viridiflavus Lacépède, 1789 and Coluber helveticus Lacépède, 1789 (currently Natrix natrix helvetica) (Reptilia, Serpentes): specific names conserved. Bull. Zool. Nom. 49: 174-175.

International Commission on Zoological Nomenclature (2017): Opinion 2381 (Case 3629) - Vipera latastei Bosca, 1878 (Reptilia, Serpentes, Viperidae): conservation of the original spelling. Bull. Zool. Nomencl. 73: 145-147.

Jablonski, D., Kukushkin, O.V., Avcı, A., Bunyatova, S., Kumlutaş, Y., Ilgaz, C., Polyakova, E., Shiryaev, K., Tuniyev, B., Jandzik, D. (2019): The biogeography of Elaphe sauromates (Pallas, 1814), with a description of a new rat snake species. PeerJ 7: e6944.

Joger, U., Lenk, P., Baran, I., Böhme, W., Ziegler, T., Heidrich, P., Wink, M. (1997): The phylogenetic position of Vipera barani and of V. nikolskii within the Vipera berus complex. In: Herpetologia Bonnensis, p. 185-194. Böhme, W., Bischoff, W., Ziegler, T., Eds, SEH, Bonn.

Kalaentzis, K., Strachinis, I., Katsiyiannis, P., Oefinger, P., Kazilas, C. (2018): New records and an updated list of the herpetofauna of Kastellorizo and the adjacent islet Psomi (Dodecanese, SE Greece). Herpetology Notes 11: 1009-1019.

Kalyabina-Hauf, S., Schweiger, S., Joger, U., Mayer, W., Orlov, N., Wink, M. (2004): Phylogeny and systematics of adders (Vipera berus complex). Mertensiella 15: 7-16.

Karin, B.R., Metallinou, M., Weinell, J.L., Jackman, T.R., Bauer, A.M. (2016): Resolving the higher-order phylogenetic relationships of the circumtropical Mabuya group (Squamata: Scincidae): an out-of-Asia diversification. Mol. Phylogenet. Evol. 102: 220-232.

Kasapidis, P., Magoulas, A., Mylonas, M., Zouros, E. (2005): The phylogeography of the gecko Cyrtopodion kotschyi (Reptilia: Gekkonidae) in the Aegean archipelago. Mol. Phylogenet. Evol. 35: 612-623.

Kieren, S., Sparreboom, M., Hochkirch, A., Veith, M. (2018): A biogeographic and ecological perspective to the evolution of reproductive behaviour in the family Salamandridae. Mol. Phylogenet. Evol. 121: 98-109.

Kindler, C., Böhme, W., Corti, C., Gvoždík, V., Jablonski, D., Jandzik, D., Metallinou, M., Široký, P., Fritz, U. (2013): Mitochondrial phylogeography, contact zones and taxonomy of grass snakes (Natrix natrix, N. megalocephala). Zool. Scr. 42: 458-472.

Kindler, C., Chèvre, M., Ursenbacher, S., Böhme, W., Hille, A., Jablonski, D., Vamberger, M., Fritz, U. (2017): Hybridization patterns in two contact zones of grass snakes reveal a new central European snake species. Sci. Rep. 7: 7378 .

Kornilios, P., Kumlutaş, Y., Lymberakis, P., Ilgaz, Ç. (2018): Cryptic diversity and molecular systematics of the Aegean Ophiomorus skinks (Reptilia: Squamata), with the description of a new species. J. Zool. Syst. Evol. Res. 56: $364-381$. 
Kornilios, P., Thanou, E. (2016): Two additions to the herpetofauna of Kasos (Aegean Sea, Greece) and the role of human-mediated dispersals. Herpetological Review 47: 633-635.

Kornilios, P., Thanou, E., Lymberakis, P., Sindaco, R., Liuzzi, C., Giokas, S. (2014): Mitochondrial phylogeography, intraspecific diversity and phenotypic convergence in the four-lined snake (Reptilia, Squamata). Zool. Scr. 43: $149-160$.

Kornilios, P., Thanou, E., Lymberakis, P., Ilgaz, C., Kumlutas, Y., Leaché, A. (2019): Genome-wide markers untangle the green-lizard radiation in the Aegean Sea and support a rare biogeographical pattern. J. Biogeogr. 46: 552-567.

Kornilios, P., Thanou, E., Lymberakis, P., Ilgaz, C., Kumlutas, Y., Leaché, A. (2020): A phylogenomic resolution for the taxonomy of Aegean green lizards. Zool. Scr. 49 : 14-27.

Kotsakiozi, P., Jablonski, D., Ilgaz, Ç., Kumlutaş, Y., Avcı, A., Meiri, S., Itescu, Y., Kukushkin, O., Gvoždík, V., Scillitani, G., Roussos, S.A., Jandzik, D., Kasapidis, P., Lymberakis, P., Poulakakis, N. (2018): Multilocus phylogeny and coalescent species delimitation in Kotschy's gecko, Mediodactylus kotschyi: hidden diversity and cryptic species. Mol. Phylogenet. Evol. 125: 177-187.

Krasylenko, Y.A., Kukushkin, O.V. (2017): An update of the thin-toed gecko Tenuidactylus bogdanovi (Reptilia, Gekkonidae) population status in Odessa City, Ukraine. Збирник праць Зоологичного музею 48 : 3-12.

Kuzmin, S.L. (1999): The Amphibians of the Former Soviet Union. Pensoft Publ., Sofia-Moscow.

Lenk, P., Joger, U., Wink, M. (2001): Phylogenetic relationships among European ratsnakes of the genus Elaphe Fitzinger based on mitochondrial DNA sequence comparisons. Amphibia-Reptilia 22: 329-339.

Lindtke, D., Mayer, W., Böhme, W. (2010): Identification of a contact zone between oviparous and viviparous common lizards (Zootoca vivipara) in central Europe: reproductive strategies and natural hybridization. Salamandra 46: $73-82$.

Litvinchuk, S.N., Zuiderwijk, A., Borkin, L.J., Rosanov, J.M. (2005): Taxonomic status of Triturus vittatus (Amphibia: Salamandridae) in western Turkey: trunk vertebrae count, genome size and allozyme data. AmphibiaReptilia 26: 305-323.

Litvinchuk, S.N., Crottini, A., Federici, S., de Pous, P., Donaire-Barroso, D., Andreone, F., Kalezić, M.L., Džukić, G., Lada, G.A., Borkin, L.J., Rosanov, J.M. (2013): Phylogeographic patterns of genetic diversity in the common spadefoot toad, Pelobates fuscus (Anura: Pelobatidae), reveals evolutionary history, postglacial range expansion and secondary contact. Org. Divers. Evol. 13: 433-451.

Ljubisavljevic, K., Orlova, V.F., Dzukic, G., Kalezic, M.L. (2006): Geographic patterns in morphological variation of the meadow lizard, Darevskia praticola (Lacertidae): taxonomical and biogeographical implications. Period. Biol. 108: 47-55.
MacCulloch, R.D., Fu, J., Darevsky, I.S., Murphy, R.W. (2000): Genetic evidence for species status of some Caucasian rock lizards in the Darevskia saxicola group. Amphibia-Reptilia 21: 169-176.

Macey, J.R., Ananjeva, N.B., Wang, Y., Papenfuss, T.J. (2000a): Phylogenetic relationships among Asian gekkonid lizards formerly of the genus Cyrtodactylus based on cladistic analyses of allozymic data: monophyly of Cyrtopodion and Mediodactylus. J. Herpetol. 34: 258-265.

Macey, J.R., Schulte, J.A., Larson, A., Ananjeva, N.B., Wang, Y., Pethiyagoda, R., Rastegar-Pouyani, N., Papenfuss, T.J. (2000b): Evaluating trans-Tethys migration: an example using acrodont lizard phylogenetics. Syst. Biol. 49: 233-256.

Maia-Carvalho, B., Gonçalves, H., Ferrand, N., MartínezSolano, I. (2014): Multilocus assessment of phylogenetic relationships in Alytes (Anura, Alytidae). Mol. Phylogenetic. Evol. 79: 270-278.

Maia-Carvalho, B., Gomes Vale, C., Sequeira, F., Ferrand, N., Martínez-Solano, I., Gonçalves, H. (2018): The roles of allopatric fragmentation and niche divergence in intraspecific lineage diversification in the common midwife toad (Alytes obstetricans). J. Biogeogr. 45: 21462158.

Márquez, R., Bosch, J. (1995): Advertisement calls of the midwife toads Alytes (Amphibia, Anura, Discoglossidae) in continental Spain. J. Zool. Syst. Evol. Res. 33: 185-192.

Martínez-Solano, I., Gonçalves, H.A., Arntzen, J.W., García-París, M. (2004): Phylogenetic relationships and biogeography of midwife toads (Discoglossidae: Alytes). J. Biogeogr. 31: 603-618.

Martínez-Solano, I., Teixeira, J., Buckley, D., García-París, M. (2006): Mitochondrial DNA phylogeography of Lissotriton boscai (Caudata, Salamandridae): evidence for old, multiple refugia in an Iberian endemic. Mol. Ecol. 15: $3375-3388$.

Marzahn, E., Mayer, W., Joger, U., Ilgaz, C., Jablonski, D., Kindler, C., Kumlutas, Y., Nistri, A., Schneeweiss, N., Vamberger, M., Zagar, A., Fritz, U. (2016): Phylogeography of the Lacerta viridis complex: mitochondrial and nuclear markers provide taxonomic insights. J. Zool. Syst. Evol. Res. 54: 85-105.

Mateo, J.A., Castroviejo, J. (1990): Variation morphologique et révision taxonomique de l'espèce Lacerta lepida Daudin, 1802 (Sauria, Lacertidae). Bulletin du Muséum d'Histoire Naturelle de Paris 12: 691-706.

Mateo, J.A., López-Jurado, L.F., Guillaume, C.P. (1996): Variabilité électrophorétique et morphologique des lézards ocellés (Lacertidae): un complexe d'espèces de part et d'autre du détroit de Gibraltar. C. R. Acad. Sci. III, Sci. Vie 319: 737-746.

Mausfeld, P., Vences, M., Schmitz, A., Veith, M. (2000): First data on the molecular phylogeography of scincid lizards of the genus Mabuya. Mol. Phylogenet. Evol. 17: 11-14.

Mausfeld, P., Schmitz, A., Böhme, W., Misof, B.Y., Vrcibradic, D., Da Rocha, C.F.D. (2002): Phylogenetic affinities of Mabuya atlantica Schmidt, 1945, Downloaded from Brill.com04/26/2023 02:26: 09PM 
endemic to the Atlantic Ocean archipelago of Fernando de Noronha (Brazil): necessity of partitioning the genus Mabuya Fitzinger, 1826 (Scincidae: Lygosominae). Zool. Anz. 241: 281-293.

Mausfeld, P., Schmitz, A. (2003): Molecular phylogeography, intraspecific variation and speciation of the Asian scincid lizard genus Eutropis Fitzinger, 1843 (Squamata: Reptilia: Scincidae): taxonomic and biogeographic implications. Org. Divers. Evol. 3: 161-171.

Mayer, W., Bischoff, W. (1996): Beiträge zur taxonomischen Revision der Gattung Lacerta (Reptilia: Lacertidae). Teil I: Zootoca, Omanosaura, Timon und Teira als eigenständige Gattungen. Salamandra 32: 163-170.

Mayer, W., Böhme, W., Tiedemann, F., Bischoff, W. (2000): On oviparous populations of Zootoca vivipara (Jacquin, 1787) in south-eastern central Europe and their phylogenetic relationship to neighbouring viviparous and southwest European oviparous populations. Herpetozoa 13: 59-69.

Mayer, W., Lutz, D. (1989): Chemosystematische Untersuchungen zur Phylogenese der Sammelgattung Lacerta (Reptilia: Sauria: Lacertidae). J. Zool. Syst. Evol. Res. 27: 338-349.

Mayer, W., Tiedemann, F. (1991): Proteinvariabilität und Taxonomie des Gran Canaria Skinks Chalcides sexlineatus. Amphibia-Reptilia 12: 121-130.

Melville, J., Hale, J., Mantziou, G., Ananjeva, N.B., Milto, K., Clem Ann, N. (2009): Historical biogeography, phylogenetic relationships and intraspecific diversity of agamid lizards in the central Asian deserts of Kazakhstan and Uzbekistan. Mol. Phylogenet. Evol. 53: 99112.

Melville, R.V., Smith, J.D.D. (1987): Official Lists and Indexes of Names and Works in Zoology. The International Commission of Zoological Nomenclature, London.

Mendes, J., Harris, D.J., Carranza, S., Salvi, D. (2016): Evaluating the phylogenetic signal limit from mitogenomes, slow evolving nuclear genes, and the concatenation approach. New insights into the Lacertini radiation using fast evolving nuclear genes and species trees. Mol. Phylogenet. Evol. 100: 254-267.

Mendes, J., Harris, D.J., Carranza, S., Salvi, D. (2017): Biogeographical crossroad across the Pillars of Hercules: evolutionary history of Psammodromus lizards in space and time. J. Biogeogr. 44: 2877-2890.

Mezzasalma, M., Dall' Asta, A., Loy, A., Cheylan, M., Lymberakis, P., Zuffi, M.A.L., Tomovic, L., Odierna, G., Guarino, F.M. (2015): A sisters' story: a multidisciplinary study on the comparative phylogeography and taxonomy of Hierophis viridiflavus and $H$. gemonensis (Serpentes, Colubridae). Zool. Scr. 44: 495-508.

Michels, J.P., Bauer, A.M. (2004): Some corrections to the scientific names of amphibians and reptiles. Bonn. Zool. Beitr. 52: 83-94.

Milto, K.D., Zinenko, O.I. (2005): Distribution and morphological variability of Vipera berus in eastern Europe. In: Herpetologia Petropolitana, p. 64-73. Ananjeva, N., Tsinenko, O., Eds, St. Petersburg.
Miraldo, A., Hewitt, G.M., Paulo, O.S., Emerson, B.C. (2011): Phylogeography and demographic history of Lacerta lepida in the Iberian Peninsula: multiple refugia, range expansions and secondary contact zones. BMC Evol. Biol. 11: 170.

Miraldo, A., Faria, C., Hewitt, G.M., Paulo, O.S., Emerson, B.C. (2013): Genetic analysis of a contact zone between two lineages of the ocellated lizard (Lacerta lepida Daudin 1802) in south-eastern Iberia reveal a steep and narrow hybrid zone. J. Zool. Syst. Evol. Res. 51: 45-54.

Mizsei, E., Jablonski, D., Roussos, S.A., Dimaki, M., Ioannidis, Y., Nilson, G., Nagy, Z.T. (2017): Nuclear markers support the mitochondrial phylogeny of Vipera ursiniirenardi complex (Squamata: Viperidae) and species status for the Greek meadow viper. Zootaxa 4227: 75-88.

Modesto, S.P., Anderson, J.S. (2004): The phylogenetic definition of Reptilia. Syst. Biol. 53: 815-821.

Molina, C., Tamar, K., González de la Vega, J.P., BurrielCarranza, B., Fernandez Guiberteau, D., Carranza, S. (in press): New records on the distribution of the Spanish sand racer species (Squamata, Psammodromus) in Spain, Iberian Peninsula. Basic Appl. Herpetol. DOI:10. 11160/bah.180.

Monzón-Arguello, C., Patiño-Martínez, C., Christiansen, F., Gallo-Barneto, R., Cabrera-Pérez, M.A., Peña-Estévez, M.A., López-Jurado, L.F., Lee, P.L.M. (2015): Snakes on an island: independent introductions have different potentials for invasion. Conserv. Genet. 16: 1225-1241.

Nagy, Z.T., Joger, U., Guicking, D., Wink, M. (2001): Phylogeography of the European Whip snake Coluber (Hierophis) viridiflavus inferred from nucleotide sequences of the mitochondrial cytochrome B gene and ISSR genomic fingerprinting. Biota 2: 38 .

Nagy, Z.T., Sonet, G., Glaw, F., Vences, M. (2012): First large-scale DNA barcoding assessment of reptiles in the biodiversity hotspot of Madagascar, based on newly designed COI primers. PLoS One 7: e34506.

Nascetti, G., Cimmaruta, R., Lanza, B., Bullini, L. (1996): Molecular taxonomy of European plethodontid salamanders (genus Hydromantes). J. Herpetol. 30: 161-183.

Nazarov, R.A., Poyarkov, N.A. (2013): A taxonomic revision of the genus Tenuidactylus Szczerbak et Golubev 1984 (Reptilia, Squamata, Gekkonidae) with a description of a new species from central Asia (in Russian). Zoological Magazine 92: 1312-1332.

Nekrasova, O.D., Kostiushyn, V.A. (2016): Current distribution of the introduced rock lizards of the Darevskia (saxicola) complex (Sauria, Lacertidae, Darevskia) in Zhytomyr region (Ukraine). Vestnik zoologii 50: 225230.

Nilson, G., Andrén, C. (1988): Vipera lebetina transmediterranea, a new subspecies of viper from North Africa, with remarks on the taxonomy of Vipera lebetina and Vipera mauritanica (Reptilia: Viperidae). Bonn. Zool. Beitr. 39: 371-379.

Pabijan, M., Crottin, A., Reckwell, D., Irisarri, I., Hauswaldt, J.S., Vences, M. (2012): A multigene species tree for Western Mediterranean painted frogs (Discoglossus). Mol. Phylogenet. Evol. 64: 690-696. 
Pabijan, M., Zieliński, P., Dudek, K., Chloupek, M., Sotiropoulos, K., Liana, M., Babik, W. (2015): The dissection of a Pleistocene refugium: phylogeography of the smooth newt, Lissotriton vulgaris, in the Balkans. J. Biogeogr. 42: 671-683.

Pabijan, M., Zieliński, P., Dudek, K., Stuglik, M., Babik, W. (2017): Isolation and gene flow in a speciation continuum in newts. Mol. Phylogenet. Evol. 116: 1-12.

Pallas, P.S. (1799): Bemerkungen auf einer Reise in die südlichen Statthalterschaften des russischen Reichs in den Jahren 1793 und 1794. Erster Band. Gottfried Martini, Leipzig.

Paolino, G., Scotti, R., Grano, M. (2019): First detection of the "flowerpot snake" Indotyphlops braminus (Daudin, 1803) (Serpentes Typhlopidae) in Ischia (Italy): a new possible invasive species. Biodivers. J. 10: 321-324.

Pasteur, G., Keymar, P., Perret, J.L. (1988): Canarian skink systematics. Contrasting insular diversifications within a species subgroup. An introduction. Ecole Pratique des Hautes Etudes ( $3^{\circ}$ section). Mémoires et Travaux de l'Institut de Montpellier 18: 1-42.

Paulo, O.S., Pinheiro, J., Miraldo, A., Bruford, M.W., Jordan, W.C., Nichols, R.A. (2008): The role of vicariance vs. dispersal in shaping genetic patterns in ocellated lizard species in the western Mediterranean. Mol. Ecol. 17: $1535-1551$.

Pavlicev, M., Mayer, W. (2009): Fast radiation of the subfamily Lacertinae (Reptilia: Lacertidae): history or methodological artefact? Mol. Phylogenet. Evol. 52: 727-734.

Pedall, I., Fritz, U., Stuckas, H., Valdeón, A., Wink, M. (2011): Gene flow across secondary contact zones of the Emys orbicularis complex in the western Mediterranean and evidence for extinction and re-introduction of pond turtles on Corsica and Sardinia (Testudines: Emydidae). J. Zool. Syst. Evol. Res. 49: 44-57.

Pereira, P., Teixeira, J., Velo-Antón, G. (2018): Allele surfing shaped the genetic structure of the European pond turtle via colonization and population expansion across the Iberian Peninsula from Africa. J. Biogeogr. 45: 22022215.

Perera, A., Vasconcelos, R., Harris, D.J., Brown, R.P., Carretero, M.A., Pérez-Mellado, V. (2007): Complex patterns of morphological and mtDNA variation in Lacerta perspicillata (Reptilia, Lacertidae). Biol. J. Linn. Soc. 90: $479-490$.

Pleguezuelos, J.M., Márquez, R., Lizana, M. (2002): Atlas y Libro Rojo de los Anfibios y Reptiles de España. Dirección General de la Conservación de la NaturalezaAsociación Herpetológica Española, Madrid.

Plötner, J., Baier, F., Akin, C., Mazepa, G., Schreiber, R., Beerli, P., Litvinchuk, S.N., Bilgin, C.C., Borkin, L., Uzzell, T. (2012): Genetic data reveal that water frogs of Cyprus (genus Pelophylax) are an endemic species of Messinian origin. Zoosyst. Evol. 88: 261-283.

Plötner, J., Uzzell, T., Beerli, P., Akın, Ç., Bilgin, C.C., Haefeli, C., Ohst, T., Köhler, F., Schreiber, R., Guex, G.-D., Litvinchuk, S.N., Westaway, R., Reyer, H.-U., Pruvost, N., Hotz, H. (2010): Genetic divergence and evolution of reproductive isolation in eastern Mediterranean water frogs. In: Evolution in Action, p. 373-403. Glaubrecht, M., Ed., Springer-Verlag, Berlin \& Heidelberg.
Pokrant, F., Kindler, C., Ivanov, M., Cheylan, M., Geniez, P., Böhme, W., Fritz, U. (2016): Integrative taxonomy provides evidence for the species status of the IberoMaghrebian grass snake Natrix astreptophora. Biol. J. Linn. Soc. 118: 873-888.

Pöschel, J., Heltai, B., Graciá, E., Quintana, M.F., VeloAntón, G., Arribas, O., Valdeón, A., Wink, M., Fritz, U., Vamberger, M. (2018): Complex hybridization patterns in European pond turtles (Emys orbicularis) in the Pyrenean region. Sci. Rep. 8: 15925.

Poulakakis, N., Pakakic, V., Mylonas, M., Lymberakis, P. (2008): Molecular phylogeny of the Greek legless skink Ophiomorus punctatissimus (Squamata: Scincidae): the impact of the mid-Aegean trench in its phylogeography. Mol. Phylogenet. Evol. 47: 396-402.

Psonis, N., Antoniou, A., Kukushkin, O., Jablonski, D., Petrov, B., Crnobrnja-Isailović, J., Sotiropoulos, K., Gherghel, I., Lymberakis, P., Poulakakis, N. (2017): Hidden diversity in the Podarcis tauricus (Sauria, Lacertidae) species subgroup in the light of multilocus phylogeny and species delimitation. Mol. Phylogenet. Evol. 106: 6-17.

Psonis, N., Antoniou, A., Karameta, E., Leaché, A.D., Kotsakiozi, P., Darriba, D., Kozlov, A., Stamatakis, A., Poursanidis, D., Kukushkin, O., Jablonski, D., Crnobrnja-Isailović, J., Gherghel, I., Lymberakis, P., Poulakakis, N. (2018): Resolving complex phylogeographic patterns in the Balkan Peninsula using closely related wall-lizard species as a model system. Mol. Phylogenet. Evol. 125: 100-115.

Pyron, R.A., Burbrink, F.T. (2009): Systematics of the common kingsnake (Lampropeltis getula; Serpentes: Colubridae) and the burden of heritage in taxonomy. Zootaxa 2241: 22-32.

Pyron, R.A., Wiens, J.J. (2011): A large-scale phylogeny of Amphibia including over 2800 species, and a revised classification of extant frogs, salamanders, and caecilians. Mol. Phylogenet. Evol. 61: 543-583.

Pyron, R.A., Burbrink, F.T., Colli, G.R., de Oca, A.N.M., Vitt, L.J., Kuczynski, C.A., Wiens, J.J. (2011): The phylogeny of advanced snakes (Colubroidea), with discovery of a new subfamily and comparison of support methods for likelihood trees. Mol. Phylogenet. Evol. 58: 329342.

Pyron, R.A., Burbrink, F.T., Wiens, J.J. (2013): A phylogeny and revised classification of Squamata, including 4161 species of lizards and snakes. BMC Evol. Biol. 13: 93.

Raffaëlli, J. (2018): Proposal for a new taxonomic arrangement of Ichthyosaura alpestris (Laurenti, 1768) (Urodela, Salamandridae), an iconic species with a complex phylogenetic structure. Alytes 36: 178-193.

Rato, C., Zuffi, M.A.L., Corti, C., Fornasiero, S., Gentilli, A., Razzetti, E., Scali, S., Carretero, M.A., Harris, D.J. (2009): Phylogeography of the European Whip Snake, Hierophis viridiflavus (Colubridae), using mtDNA and nuclear DNA sequences. Amphibia-Reptilia 30: 283289.

Raxworthy, C.J. (1990): A review of the smooth newt (Triturus vulgaris) subspecies, including and identification key. Herpetol. J. 1: 481-492. 
Rebelo, L. (2008): Tarentola bischoffi Joger, 1984. Osgadas-Selvagens. In: Atlas dos Anfíbios e Répteis de Portugal, p. 188-189. Loureiro, A., Ferrand de Almeida, N., Carretero, M.A., Paulo, O.S., Eds, Instituto de Conservação da Natureza e da Biodiversidade, Lisboa.

Recuero, E., Buckley, D., García-París, M., Arntzen, J.W., Cogălniceanu, D., Martínez-Solano, I. (2014): Evolutionary history of Ichthyosaura alpestris (Caudata, Salamandridae) inferred from the combined analysis of nuclear and mitochondrial markers. Mol. Phylogenet. Evol. 81: $207-220$.

Recuero, E., Canestrelli, D., Vörös, J., Szabó, K., Poyarkov, N.A., Arntzen, J.W., Crnobrnja-Isailovic, J., Kidov, A.A., Cogălniceanu, D., Caputo, F.P., Nascetti, G., Martínez-Solano, I. (2012): Multilocus species tree analyses resolve the radiation of the widespread Bufo bufo species group (Anura, Bufonidae). Mol. Phylogenet. Evol. 62: 71-86.

Richter, K. (1980): Lacerta dugesii Milne-Edwards, 1829 und Lacerta perspicillata Duméril et Bibron, 1839 gehören zur Gattung Podarcis Wagler, Subgenus Teira Gray, 1838. Zool. Abh. Staatl. Mus. Tierkde. Dresden 36: $1-9$.

Rösler, H., Schmidtler, J.F., Moravec, J. (2012): Bemerkungen zu einigen Unterarten von Mediodactylus kotschyi (Steindachner, 1870) und Mediodactylus heterocercus mardinensis (Mertens, 1924) in der Südlichen Türkey und in angrenzenden Gebieten (Squamata: Sauria: Gekkonidae). Herpetozoa 25: 24-46.

Ruggiero, M.A., Gordon, D.P., Orrell, T.M., Bailly, N., Bourgoin, T., Brusca, R.C., Cavalier-Smith, T., Guiry, M.D., Kirk, P.M. (2015): A higher level classification of all living organisms. PLoS ONE 10: e0119248.

Sá-Sousa, P., Mateo Miras, J.A., Pérez-Mellado, V., Martínez-Solano, I. (2009): Tarentola boettgeri. The IUCN Red List of Threatened Species 2009: e.T61574A12494311.

Sagonas, K., Poulakakis, N., Lymberakis, P., Parmakelis, A., Pafilis, P., Valakos, E.D. (2014): Molecular systematics and historical biogeography of the green lizards (Lacerta) in Greece: insights from mitochondrial and nuclear DNA. Mol. Phylogenet. Evol. 76: 144-154.

Salvador, A., Brown, R.P. (2015): Lisa grancanaria - Chalcides sexlineatus. In: Enciclopedia Virtual de los Vertebrados Españoles. Salvador, A., Marco, A., Eds, Museo Nacional de Ciencias Naturales, Madrid.

Salvador, A., Busack, S.D., McDiarmid, R., Ineich, I., Brito, J.C. (2014): Vipera latastei Boscá, 1878 (Reptilia, Serpentes, Viperidae): request for conservation of the original spelling. Bull. Zool. Nomencl. 71: 22-25.

Salvi, D., Mendes, J., Carranza, S., Harris, D.J. (2018): Evolution, biogeography and systematics of the western Palaearctic Zamenis ratsnakes. Zool. Scr. 47: 441-461.

Sampaio, F.L., Harris, D.J., Perera, A., Salvi, D. (2015): Phylogenetic and diversity patterns of Blanus worm lizards (Squamata: Amphisbaenia): insights from mitochondrial and nuclear gene genealogies and species tree. J. Zool. Syst. Evol. Res. 53: 45-54.
Sánchez-Vialas, A., Calvo-Revuelta, M., Rubio, J.L., Palacios, F., García-París, M. (2018): Taxonomic and nomenclatural status of Iberian Algyroides (Lacertidae). Amphibia-Reptilia 40: 91-102.

Sarayev, F.A., Pestov, M.V. (2010): On the cadastre of the reptiles of northern and northeastern Caspian Sea regions. In: Herpetological Studies in Kazakhstan and Adjacent Countries: Collection of Scientific Papers, p. 172191. Almaty. (In Russian, English summary).

Schätti, B., Vanni, S. (1986): Intraspecific variation in Coluber viridiflavus Lacépède, 1789, and validity of its subspecies (Reptilia, Serpentes, Colubridae). Rev. Suisse Zool. 93: 219-232.

Schmidtler, J.F. (1997): Die Ablepharus kitaibelii - Gruppe in Süd-Anatolien und benachtbarten Gebieten. Herpetozoa 10: $35-63$.

Schneider, H. (1974): Structure of the mating calls and relationships of the European tree frogs (Hylidae, Anura). Oecologia 14: 99-110.

Senczuk, G., Castiglia, R., Böhme, W., Corti, C. (2019): Podarcis siculus latastei (Bedriaga, 1879) of the Western Pontine Islands (Italy) raised to the species rank, and a brief taxonomic overview of Podarcis lizards. Acta Herpetologica 14: 71-80.

Senczuk, G., Colangelo, P., De Simone, E., Aloise, G., Castiglia, R. (2017): A combination of long term fragmentation and glacial persistence drove the evolutionary history of the Italian wall lizard Podarcis siculus. BMC Evol. Biol. 17: 6.

Senczuk, G., Havenstein, K., Milana, V., Ripa, C., De Simone, E., Tiedemann, R., Castiglia, R. (2018): Spotlight on islands: on the origin and diversification of an ancient lineage of the Italian wall lizard Podarcis siculus in the western Pontine Islands. Sci. Rep. 8: 15111.

Sequeira, F., Bessa-Silva, A., Tarroso, P., Sousa-Neves, T., Vallinoto, M., Gonçalves, H., Martínez-Solano, I. (2020): Discordant patterns of introgression across a narrow hybrid zone between two cryptic lineages of an Iberian endemic newt. J. Evol. Biol. 33: 202-216.

Sillero, N., Campos, J., Bonardi, A., Corti, C., Creemers, R., Crochet, P.-A., Crnobrnja Isailović, J., Denoël, M., Ficetola, G.F., Gonçalves, J., Kuzmin, S., Lymberakis, P., de Pous, P., Rodríguez, A., Sindaco, R., Speybroeck, J., Toxopeus, B., Vieites, D.R., Vences, M. (2014): Updated distribution and biogeography of amphibians and reptiles of Europe. Amphibia-Reptilia 35: 1-31.

Sindaco, R., Jeremčenko, V.K. (2008): The Reptiles of the Western Palearctic. 1. Annotated Checklist and Distributional Atlas of the Turtles, Crocodiles, Amphisbaenians and Lizards of Europe, North Africa, Middle East and Central Asia. Monografie Della Societas Herpetologica Italica. Edizioni Belvedere, Latina.

Sindaco, R., Venchi, A., Grieco, C. (2013): The reptiles of the Western Palearctic 2. Annotated checklist and distributional Atlas of the snakes of Europe, North Africa, the Middle East and Central Asia, with an update to the vol. 1. Latina, Societas Herpetologica Italica.

Skorinov, D.V., Bolshakova, D.S., Donaire, D., Pasynkova, R.A., Litvinchuk, S. (2018): Karyotypic analysis of the spined toad, Bufo spinosus Daudin, 1803 (Amphibia: Bufonidae). Russ. J. Herpetol. 25: 253-258. 
Skourtanioti, E., Kapli, P., Ilgaz, Ç., Kumlutaş, Y., Avcı, A., Ahmadzadeh, F., Crnobrnja-Isailović, J., Gherghel, I., Lymberakis, P., Poulakakis, N. (2016): A reinvestigation of phylogeny and divergence times of the Ablepharus kitaibelii species complex (Sauria, Scincidae) based on mtDNA and nuDNA genes. Mol. Phylogenet. Evol. 103: 199-214.

Sobolevsky, N.I. (1930): New form from genus Lacerta (Reptilia) from Hungary. Trudy Assotsiatsili ssledovatel'skii Institutov pri Fiziko-Matematicheskom Fakul'tete 1 MGU 3: 3-9.

Sotiropoulos, K., Eleftherakos, K., Džukić, G., Kalezić, M.L., Legakis, A., Polymeni, R.M. (2007): Phylogeny and biogeography of the Alpine newt Mesotriton alpestris (Salamandridae, Caudata), inferred from mtDNA sequences. Mol. Phylogenet. Evol. 45: 211-226.

Speybroeck, J., Beukema, W., Bok, B., Van Der Voort, J. (2016): Field Guide to the Amphibians and Reptiles of Britain and Europe. Bloomsbury, London.

Speybroeck, J., Beukema, W., Crochet, P.-A. (2010): A tentative species list of the European herpetofauna (Amphibia and Reptilia) - an update. Zootaxa 2492: 1-27.

Speybroeck, J., Crochet, P.-A. (2007): Species list of the European herpetofauna - a tentative update. Pod@rcis 8: 8-34.

Spilani, L., Bougiouri, K., Antoniou, A., Psonis, N., Poursanidis, D., Lymberakis, P., Poulakakis, N. (2019): Multigene phylogeny, phylogeography and population structure of Podarcis cretensis species group in south Balkans. Mol. Phylogenet. Evol. 138: 193-204.

Štěpánek, O. (1937): Gymnodactylus kotschyi Steindachner und sein Rassenkreis. Archiv für Naturgeschichte, Zeitschrift für Systematische Zoologie 6: 258-280.

Štěpánek, O. (1939): Gymnodactylus kotschyi kalypsae n. subsp. Věstník ČeskoslovenskÉ Zoologické Společnosti v Praze 6-7: 431-435.

Stöck, M., Dubey, S., Klütsch, C., Litvinchuk, S.N., Scheidt, U., Perrin, N. (2008): Mitochondrial and nuclear phylogeny of circum-Mediterranean tree frogs from the Hyla arborea group. Mol. Phylogenet. Evol. 49: 10191024.

Stöck, M., Moritz, C., Hickerson, M., Frynta, D., Dujsebayeva, T., Eremchenko, V., Macey, J.R., Papenfuss, T.J., Wake, D.B. (2006): Evolution of mitochondrial relationships and biogeography of Palearctic green toads (Bufo viridis subgroup) with insights in their genomic plasticity. Mol. Phylogenet. Evol. 41: 663-689.

Stugren, B. (1961): Systematik der Wieseneidechse Lacerta praticola Eversmann. Zool. Beitr. 6: 379-390.

Stugren, B. (1984): Lacerta praticola Eversmann 1834 Wieseneidechse. In: Handbuch der Reptilien und Amphibien Europas. Band 2/I Echsen II (Lacerta), p. 318331. Böhme, W., Ed., AULA-Verlag, Wiesbaden.

Stugren, B., Tassoula, P. (1987): Uber die wechselkröte (Bufo viridis Laur.) aus Zypern. Studia Univ. BabesBolyai Biologia 32: 2.

Stümpel, N. (2012): Phylogenie und Phylogeographie eurasischer Viperinae unter besonderer Berücksichtigung der orientalischen Vipern der Gattungen Montivipera und Macrovipera. PhD Thesis, TU Carolo-Wilhelmina zu Braunschweig.
Stümpel, N., Joger, U. (2009): Recent advances in phylogeny and taxonomy of near and middle eastern vipers - an update. ZooKeys 31: 179-191.

Suárez, N.M., Pestano, J., Brown, R.P. (2014): Ecological divergence combined with ancient allopatry in lizard populations from a small volcanic island. Mol. Ecol. 23: 4799-4812.

Surget-Groba, Y., Heulin, B., Guillaume, C.P., Thorpe, R., Kupriyanova, L. (2001): Intraspecific phylogeography of Lacerta vivipara and the evolution of viviparity. Mol. Phylogenet. Evol. 18: 449-459.

Surget-Groba, Y., Heulin, B., Ghielmi, S., Guillaume, C.P., Vogrin, N. (2002): Phylogeography and conservation of the populations of Zootoca vivipara carniolica. Biol. Conserv. 106: 365-372.

Szczerbak, N.N., Golubev, M.L. (1996): Gecko Fauna of the USSR and Contiguous Regions. Society for the Study of Amphibians and Reptiles.

Tarkhnishvili, D., Gabelaia, M., Mumladze, L., Murtskhvaladze, M. (2016): Mitochondrial phylogeny of the Darevskia saxicola complex: two highly deviant evolutionary lineages from the easternmost part of the range. Herp. J. 26: 175-182.

Teixeira, J., Martínez-Solano, I., Buckley, D., Tarroso, P., García París, M., Ferrand, N. (2015): Genealogy of the nuclear $\beta$-fibrinogen intron 7 in Lissotriton boscai (Caudata, Salamandridae): concordance with mtDNA and implications for phylogeography and speciation. Contr. Zool. 84: 193-215.

Tourneville, A. (1879): Description d'une nouvelle espèce de batracien urodèle d'espagne (Pelonectes boscai Lataste). Bulletin de la Société Zoologique de France 4: 69-87.

Tuniyev, B.S., Ostrovskikh, S.V. (2001): Two new species of vipers of "kaznakovi" complex (Ophidia, Viperinae) from the western Caucasus. Russ. J. Herpetol. 8: 118126.

Tuniyev, B.S., Tuniyev, S.B. (2012): On distribution and taxonomic status of rock lizards Darevskia brauneri szczerbaki (Lukina, 1963) and D. b. darevskii (Szczerbak, 1962). Russ. J. Herpetol. 19: 10-22.

Tuniyev, S.B., Orlov, N.L., Tuniyev, B.S., Kidov, A.A. (2013): On the taxonomical status of steppe viper from foothills of the south macroslope of the east Caucasus. Russ. J. Herpetol. 20: 129-146.

Tuniyev, S.B., Doronin, I.V., Kidov, A.A., Tuniyev, B.S. (2011): Systematic and geographical variability of meadow lizard, Darevskia praticola (Reptilia: Sauria) in the Caucasus. Russ. J. Herpetol. 18: 295-316.

Tuniyev, S.B., Doronin, I.V., Tuniyev, B.S., Aghasyan, A.L., Kidov, A.A., Aghasyan, L.A. (2013): New subspecies of meadow lizard, Darevskia praticola loriensis ssp. nov. (Reptilia: Sauria) from Armenia. Russ. J. Herpetol. 20: 223-237.

Uetz, P., Freed, P., Hošek, J., Eds (2019): The Reptile Database, http://www.reptile-database.org, accessed 30/12/2019.

Ursenbacher, S., Carlsson, M., Helfer, V., Tegelström, H., Fumagalli, L. (2006): Phylogeography and Pleistocene refugia of the adder (Vipera berus) as inferred from mitochondrial DNA sequence data. Mol. Ecol. 15: 34253437. 
Vamberger, M., Stuckas, H., Sacco, F., D’Angelo, S., Arculeo, M., Cheylan, M., Corti, C., Lo Valvo, M., Marrone, F., Wink, M., Fritz, U. (2015): Differences in gene flow in a twofold secondary contact zone of pond turtles in southern Italy (Testudines: Emydidae: Emys orbicularis galloitalica, E. o. hellenica, E. trinacris). Zool. Scr. 44: 233-249.

Vamberger, M., Fritz, U. (2018): Big data can cause big mistakes: using the Societas Europaea Herpetologica atlas by Sillero et al. (2014), the distribution of Emys orbicularis will be misunderstood. Biologia 73: 281283.

Van Bocxlaer, I., Biju, S.D., Loader, S.P., Bossuyt, F. (2009): Toad radiation reveals into-India dispersal as a source of endemism in the Western Ghats-Sri Lanka biodiversity hotspot. BMC Evol. Biol. 9: 131.

Van Bocxlaer, I., Loader, S.P., Roelants, K., Biju, S.D., Menegon, M., Bossuyt, F. (2010): Gradual adaptation toward a range-expansion phenotype initiated the global radiation of toads. Science 327: 679-682.

Van de Koppel, S., van Kessel, N., Crombaghs, B.H.J.M., Getreuer, W., Lenders, H.J.R. (2012): Risk Analysis of the Russian Rat Snake (Elaphe schrenckii) in the Netherlands. Nijmegen, Natuurbalans - Limes Divergens BV, Delft, ReptielenZoo SERPO, Nijmegen, Radboud University.

van de Vliet, M.S., Beebee, T.J., Diekmann, O.E. (2012): Genetic evidence for a distinct Pelodytes lineage in southwest Portugal: implications for the use of predeveloped microsatellite markers. Conserv. Genet. 13: 605-611.

van Riemsdijk, I., Arntzen, J.W., Bogaerts, S., Franzen, M., Litvinchuk, S.N., Olgun, K., Wielstra, B. (2017): The near east as a cradle of biodiversity: a phylogeography of banded newts (genus Ommatotriton) reveals extensive inter-and intraspecific genetic differentiation. Mol. Phylogenet. Evol. 114: 73-81.

van Riemsdijk, I., van Nieuwenhuize, L., Martínez-Solano, I., Arntzen, J.W., Wielstra, B. (2018): Molecular data reveal the hybrid nature of an introduced population of banded newts (Ommatotriton) in Spain. Conserv. Genet. 19: 249-254.

Veith, M., Bogaerts, S., Pasmans, F., Kieren, S. (2018): The changing views on the evolutionary relationships of extant Salamandridae (Amphibia: Urodela). PLoS ONE 13: e0198237.

Veith, M., Baumgart, A., Dubois, A., Ohler, A., Galán, P., Vieites, D.R., Nieto-Román, S., Vences, M. (2012): Discordant patterns of nuclear and mitochondrial introgression in Iberian populations of the European common frog (Rana temporaria). J. Hered. 103: 240-249.

Veith, M., Vences, M., Vieites, D.R., Nieto-Roman, S., Palanca-Soler, A. (2002): Genetic differentiation and population structure within Spanish common frogs (Rana temporaria complex; Ranidae, Amphibia). Folia Zool. 51: 307-318.

Velo-Antón, G., Pereira, P., Fahd, S., Teixeira, J., Fritz, U. (2015): Out of Africa: did Emys orbicularis occidentalis cross the Strait of Gibraltar twice? Amphibia-Reptilia 36: $133-140$.
Vences, M. (1992): Zur Biologie der nordwestspanischen Braunfrösche Rana iberica Boulenger, 1879 und Rana temporaria parvipalmata Seoane, 1885. Salamandra 28: 61-71.

Vences, M., Guayasamin, J.M., Miralles, A., de la Riva, I. (2013a): To name or not to name: criteria to promote economy of change in Linnaean classification schemes. Zootaxa 3636: 201-244.

Vences, M., Hauswaldt, J.S., Steinfartz, S., Rupp, O., Goesmann, A., Künzel, S., Orozco-ter Wengel, P., Vieites, D.R., Nieto-Roman, S., Haas, S., Laugsch, C., Gehara, M., Bruchmann, S., Pabijan, M., Ludewig, A.K., Rudert, D., Angelini, C., Borkin, L.J., Crochet, P.A., Crottini, A., Dubois, A., Ficetola, G.F., Galán, P., Geniez, P., Hachtel, M., Jovanovic, O., Litvinchuk, S.N., Lymberakis, P., Ohler, A., Smirnov, N.A. (2013b): Radically different phylogeographies and patterns of genetic variation in two European brown frogs, genus Rana. Mol. Phylogenet. Evol. 68: 657-670.

Vences, M., Sanchez, E., Hauswaldt, J.S., Eikelmann, D., Rodríguez, A., Carranza, S., Donaire, D., Gehara, M., Helfer, V., Lötters, S., Werner, P., Schulz, S., Steinfartz, S. (2014): Nuclear and mitochondrial multilocus phylogeny and survey of alkaloid content in true salamanders of the genus Salamandra (Salamandridae). Mol. Phylogenet. Evol. 73: 208-2016.

Vences, M., Sarasola-Puente, V., Sanchez, E., Amat, F., Hauswaldt, J.S. (2017): Diversity and distribution of deep mitochondrial lineages of the common frog, Rana temporaria, in northern Spain. Salamandra 53: 25-33.

Vörös, J., Ursenbacher, S., Jelić, D. (2019): Population genetic analyses using 10 new polymorphic microsatellite loci confirms genetic subdivision within the olm, Proteus anguinus. J. Hered. 2: 211-218.

Wagler, J.G. (1830): Natürliches System der Amphibien, mit vorangehender Classification der Säugethiere und Vögel ein Beitrag zur vergleichenden Zoologie. G. J. Cotta'schen Buchhandlung, München, Stuttgart and Tubingen.

Wagner, P., Tiutenko, A., Mazepa, G., Borkin, L.J., Simonov, E. (2016): Alai! Alai! - a new species of the Gloydius halys (Pallas, 1776) complex (Viperidae, Crotalinae), including a brief review of the complex. Amphibia-Reptilia 37: 15-31.

Wake, D.B. (2012): Taxonomy of salamanders of the family Plethodontidae (Amphibia: Caudata). Zootaxa 3484: 75-82.

Wake, D.B. (2013): The enigmatic history of the European, Asian and American plethodontid salamanders. Amphibia-Reptilia 34: 323-336.

Weisrock, D.W., Papenfuss, T.J., Macey, J.R., Litvinchuk, S.N., Polymeni, R.M., Uğurtaş, I.H., Zhao, E., Jowkar, H., Larson, A. (2006): A molecular assessment of phylogenetic relationships and lineage accumulation rates with the family Salamandridae (Amphibia, Caudata). Mol. Phylogenet. Evol. 41: 368-383.

Whiting, A.S., Sites, J.W. Jr., Pellegrino, K.C.M., Rodrigues, M.T. (2006): Comparing alignment methods for inferring the history of the new world lizard genus Mabuya (Squamata: Scincidae). Mol. Phylogenet. Evol. 38: 719-730. 
Wielstra, B., Litvinchuk, S., Naumov, B., Tzankov, N., Arntzen, J.W. (2013): A revised taxonomy of crested newts in the Triturus karelinii group (Amphibia: Caudata: Salamandridae), with the description of a new species. Zootaxa 3682: 441-453.

Wielstra, B., Arntzen, J.W. (2014): Kicking Triturus arntzeni when it's down: large-scale nuclear genetic data confirm that newts from the type locality are genetically admixed. Zootaxa 3802: 381-388.

Wielstra, B., Canestrelli, D., Cvijanović, M., Denoël, M., Fijarczyk, A., Jablonski, D., Liana, M., Naumov, B., Olgun, K., Pabijan, M., Pezzarossa, A., Popgeorgiev, G., Salvi, D., Si, Y., Sillero, N., Sotiropoulos, K., Zieliński, P., Babik, W. (2018): The distributions of the six species constituting the smooth newt species complex (Lissotriton vulgaris sensu lato and $L$. montandoni) - an addition to the new atlas of amphibians and reptiles of Europe. Amphibia-Reptilia 39: 252-259.

Zamora-Camacho, F.J. (2017): On the role of plant nurseries introducing Indotyphlops braminus (Daudin, 1803), in Spain. Herpetozoa 30: 69-72.

Zhang, P., Papenfuss, T.J., Wake, M.H., Qu, L., Wake, D.B. (2008): Phylogeny and biogeography of the family Salamandridae (Amphibia: Caudata) inferred from complete mitochondrial genomes. Mol. Phylogenet. Evol. 49: 586-597.

Zheng, Y., Wiens, J.J. (2016): Combining phylogenomic and supermatrix approaches, and a time-calibrated phylogeny for squamate reptiles (lizards and snakes) based on 52 genes and 4162 species. Mol. Phylogenet. Evol. 94: $537-547$

Zinenko, O. (2004): New data about hybridization between Vipera nikolskii Vedmederya, Grubant et Rudaeva, 1986 and Vipera berus berus (Linnaeus, 1758) and their contact zones in Ukraine. Mertensiella 15: 17-28.

Zinenko, O., Ţurcanu, V., Strugariu, A. (2010): Distribution and morphological variation of Vipera berus nikolskii Vedmederja, Grubant et Rudaeva, 1986 in Western Ukraine, the Republic of Moldova and Romania. Amphibia-Reptilia 31: 51-67.

Zinenko, O., Sovic, M., Joger, U., Gibbs, H.L. (2016): Hybrid origin of European vipers (Vipera magnifica and Vipera orlovi) from the Caucasus determined using genomic scale DNA markers. BMC Evol. Biol. 16: 76.

Zinenko, O., Stümpel, N., Mazanaeva, L., Bakiev, A., Shiryaev, K., Pavlov, A., Kotenko, T., Kukushkin, O., Chikin, Y., Duisebayeva, T., Nilson, G., Orlov, N.L., Tuniyev, S., Ananjeva, N.B., Murphy, R.W., Joger, U. (2015): Mitochondrial phylogeny shows multiply independent ecological transitions and northern dispersion despite of Pleistocene glaciations in meadow and steppe vipers (Vipera ursinii and Vipera renardi). Mol. Phylogenet. Evol. 84: 85-100.

Submitted: February 13, 2020. Final revision received: April 20, 2020. Accepted: April 20, 2020.

Associate Editor: Salvador Carranza. 